\title{
ECOLOGICAL INFORMATION OF RING WIDTH, STABLE CARBON ISOTOPE COMPOSITION AND WOOD ANATOMICAL VARIABLES IN TROPICAL TREE RINGS - A CONTRIBUTION TO DENDROCHRONOLOGY IN THE TROPICS
}

\author{
DISSERTATION \\ ZUR ERLANGUNG DES DOKTORGRADES \\ DER FAKULTÄT FÜR FORSTWISSENSCHAFTEN UND WALDÖKOLOGIE \\ DER GEORG-August-UNIVERSITÄT GÖTTINGEN
}

VORGELEGT VON

ESTHER FICHTLER

GEBOREN IN NEUSTADT AN DER WEINSTRAßE, DEUTSCHLAND

GÖTTINGEN, FEBRUAR 2011 
1. GUTAChTER: PD DR. MARTIN WORBES

2. GUTACHTER: Prof. DR. RUPERT WIMMER

TAG DER MÜNDLICHen PRÜFUNG: 05.05.2011 
To Martin, Helena \& BJARnE

-YOU COMPLETE ME! 



\section{CONTENTS}

$\begin{array}{llr}\text { CHAPTER } 1 & \text { GENERAL INTRODUCTION }\end{array}$

$\begin{array}{lll}\text { Chapter } 2 \text { WoOd ANATOMY AND Tree-Ring Structure } & 15\end{array}$ AND THEIR IMPORTANCE FOR TROPICAL DENDROCHRONOLOGY

CHAPTER 3

CLIMATIC SIGNALS IN TREE RINGS OF BURKEA AFRICANA AND PTEROCARPUS ANGOLENSIS FROM SEMIARID FORESTS IN NAMIBIA

CHAPTER 4 STABLE-CARBON ISOTOPE TIME SERIES FROM TROPICAL TREE RINGS INDICATE A PRECIPITATION SIGNAL

CHAPTER 5

WoOD ANATOMICAL VARIABLES IN TROPICAL TREES AND THEIR RELATION TO SITE CONDITIONS AND INDIVIDUAL TREE MORPHOLOGY 



\section{GENERAL INTRODUCTION}

\section{THE IMPORTANCE OF TROPICAL FORESTS AND TREES}

Tropical forests include four biomes: moist broadleaf, dry broadleaf, coniferous and mangrove forests (Olsen et al. 2001). They fulfil important productive functions including production of timber, fuel wood and non-timber forest products as well as social functions by providing subsistence for local populations and cultures (Montagini \& Jordan 2005). Other important aspects are the manifold environmental functions of tropical forests e.g. the influence on global hydrological cycles. Evapotranspiration from tropical forests contribute to precipitation at higher latitudes as well as within the tropics (Avissar \& Werth 2005). These ecosystems are hotspots of global biodiversity and contain over half of all described species (Groombridge \& Jenkins 2003). Moreover, tropical forests are a critical component of the global carbon cycle, accounting for $32 \%$ of net terrestrial carbon stocks and primary productivity (Dixon et al. 1994, Field et al. 1998).

Taking into account these ecological aspects and the large share of tropical forests (about $47 \%$ ) of total global forest area, the understanding of tropical forest ecology and the evaluation of ongoing global climate change effects on tropical forests is of major importance. Yet no conclusive results exist on the effect of increasing $\mathrm{CO}_{2}$ concentrations and elevated temperature. Whereas some studies have reported an increase in growth rate of tropical forest trees in response to global change due to physiological benefits of increasing levels of atmospheric $\mathrm{CO}_{2}$ dominating over negative temperature effects (Lewis et al. 2004), others have reported a decrease in growth rate and declining productivity because of an increase in drought severity (Feeley et al. 2007). This lack of agreement is of great concern because determining the growth rates of tropical trees is crucial to determine and predict global carbon budgets (Houghton 2007, Caspersen et al. 2000).

It is obvious that major research gaps exist concerning the dynamics in tropical forests, their resilience to drought and their status as carbon sinks. Interactions between climate and disturbances such as fires, aerosols, and reactive gases and the effects of small-scale deforestation on cloud formation and precipitation are key unknowns (Bonan 2008). Projections concerning the effects of global change on forests remain highly uncertain (Clark 
\& Clark 2011) due to the scarcity of long-term climate data as well as field data on the response of trees to changing environmental conditions. And above all, only little is known on the age and life history of tropical tree species itself (Worbes \& Junk 1999).

Trees are long living organisms and record ecologically relevant information in their growth rings. Radial tree growth is the result of various internal and external factors. Internal factors include the genetic background of the tree modulated by age and allometric growth trends including carbon allocation (e.g. masting). External factors represent regional climate conditions, disturbances as well as abiotic (nutrient availability) and biotic (competition, pathogens) site conditions (Cook 1987). Wood production and anatomy throughout the tree is strongly determined by the three major functions of wood: biomechanical support, water and nutrient transport as well as storage capacity for water, nutrients and chemical compounds such as carbohydrates and lipids (Chave et al. 2009). These demands can shift through time depending on the ontogenetic stage of the tree (Poorter \& Kitajima 2007) but also depending on changes in the regional or local environment (Wimmer 2002).

\section{DENDROCHRONOLOGY IN TROPICAL TREE SPECIES}

For temperate-zone tree species, dendrochronological methods have been getting increasingly sophisticated in the last 45 years (overviews in Schweingruber 1996, Vaganov et al. 2006). The relevance of dendrochronology in global change studies is obvious as witnessed by the use of Northern hemisphere tree-ring data in reconstructions of temperature (Mann et al. 2003, Esper et al. 2002) and precipitation (Trouet et al. 2009, Büntgen et al. 2011). For tropical trees, in contrast, common dendrochronological methods have long been presumed to be impractical because tropical trees were supposed to not form distinct annual growth rings. Recent studies, however, have successfully applied dendrochronological methods on tropical trees (extensive overviews in Worbes 2002, Rozendaal \& Zuidema 2011). Nevertheless, the vast majority of tree-ring studies are carried out in extra-tropical regions, while analyzing tropical trees is still regarded as a challenging task (Bräuning 2011).

Tropical trees, like their temperate counterparts, show cambial dormancy in response to seasonality in climate-related factors such as temperature or flooding (water stress) and particularly rainfall (drought stress). Nearly all tropical regions experience some form of seasonality by either drought or flooding for days or months. Most tropical tree species 
respond to these changes of environmental factors by showing reduction of radial growth and changes in wood anatomical structures leading to the formation of growth rings visible in the cross-section of the tree stems (Worbes 1985). These growth rings are annual, if the triggering climate factors occur once a year (Worbes 1995).

To identify growth rings and to analyze growth-ring patterns, stem discs taken from the stem base should be investigated. Tree growth can then be analysed retrospectively over the entire life span of a tree and in relation to climate data. This technique provides information not only on the trees' relative growth rates over time and the time needed to accumulate the actual biomass for single trees, but also on long-term species performance and stand history as well as a possible relation to climate variability.

In this way, annual tree-ring patterns of tropical tree species represent a reliable basis that can be used in various ways to gain information on forest dynamics (e.g. Worbes et al. 1992, Brienen \& Zuidema 2006a), tree ages (e.g. Worbes \& Junk 1999, Fichtler et al. 2003) growth rates (e.g. Worbes et al. 2003), climate reconstructions (e.g. Worbes 1999a, Schöngart et al. 2004) to estimate management criteria (e.g. Brienen \& Zuidema 2006b, Schöngart 2008) and changes in the C-stocks of above-ground coarse wood biomass (Schöngart et al. 2010).

\section{RATIONALE OF THE PRESENT STUDY}

Since more than 100 years the existence of tropical tree rings is reported (for a historical overview see Worbes 2002). In the last two decades, many studies have proven the annual nature of rings in tree species in tropical regions from arid zones (Gourlay 1995, Stahle et al. 1999, Fichtler et al. 2004, Trouet et al. 2006) to humid zones (Fichtler et al. 2003, Couralet et al. 2010), inundation forests (Worbes 1985, Schöngart et al. 2002), mangroves (Menezes et al. 2003, Verheyden et al. 2004) and swamps (Callado et al. 2001). Unlike in temperate zones, relatively few applications were developed for tropical regions (e.g. Worbes et al. 2003, Schöngart et al. 2004, 2006, Brienen and Zuidema 2006a,b, Zuidema et al. 2011, Pumijumnong \& Eckstein 2011). Inter alia, this is caused by limited technical facilities and financial resources in tropical countries themselves, but also difficult-to-access stands, low sampling replication because of the enormous species diversity that comes along with low abundances of individuals of any particular species in most tropical forests. Furthermore, standard non-destructive methods like coring are not suitable for most tropical trees. Easily 
accessible forest stands are often protected, and exportation of wood discs is subject to strict regulations or even prohibited.

In any case, the most serious obstacle is that most tropical broadleaf tree species show by far more variable growth ring structures compared to temperate broadleaf or conifer species. Many examples showed that even distinct tree-ring boundaries underlie a broad variability within a species and among individuals: sometimes ring boundaries are undefined near the center of the disc, whereas they are quite distinct in the outer region near the bark (Coster 1927). Some species form distinct ring boundaries in their juvenile stage, later either undefined rings or narrow rings of very few or single cell rows that can hardly be distinguished. In certain taxa tree species tend to form wedging rings meaning that tree rings merge due to a failure of cambial activity at certain positions of the stem (Worbes 1996). In other species, the identification of tree rings is more difficult, because boundaries may tend to gradually disappear or break-off. Finally, various species show generally undefined boundaries, especially under high magnification. Nevertheless, a large number of species produces regular growth ring structures. The successful application of standard dendrochronological methods in tropical trees with highly variable ring structures is possible by a diligent wood anatomical examination on every sample to ensure the recognition of all ring boundaries. Therefore tropical trees are important research objects that might encode manifold ecological information in their tree ring sequences. This information contributes to the solution of diverse unanswered questions in tropical forest ecology as well as global change.

Many successful studies on tropical tree rings focussed on very few species with regular ring structures or with high importance for sustainable forest management (Schöngart 2008, Schöngart et al. 2007, Brienen \& Zuidema 2006b). In this context understorey species and community based effects have been regarded to a lesser extent only (e.g. Worbes et al. 2003, Schöngart et al. 2002, Brienen et al. 2009, Couralet et al. 2010).

The basic idea of the present dissertation was to develop standardized guidance to determine age and growth rates of tropical tree species in general. Thereby the identification of wood anatomical features in many different tree families and species from tropical regions with differences in seasonality in climate was of major interest. The aim was to enhance possibilities to reliably detect and describe features of tree-ring boundaries and their highly variable appearance. Emphasis was put on a macroscopic methodology (i) to allow growthring inspection on whole stem discs by checking variation in wood anatomy and hence distinctiveness of boundaries around the circumference and (ii) to ease the possible 
application in tropical regions, where microscopic facilities could be rare. In addition macroscopic analyses are less time consuming, allowing a higher work flow. For this purpose, all analyses were performed on polished cross-sectional stem surfaces with low magnifications, while all parameters described could be followed also with an elementary hand lens. Hence many wood-anatomical parameters, commonly used in 'conventional' wood anatomical studies, will not be mentioned in the following chapters.

Besides the qualitative wood-anatomical description of tree-ring boundaries in tropical trees, a further objective was to identify new quantitative parameters to determine ring boundaries. Therefore stable carbon isotopes were analyzed together with wood-anatomical variables along radial tree-ring sequences. The profiles were examined with respect to changes that would indicate annual cycles and hence could be used to verify annual growthring formation. In addition these quantitative variables were evaluated concerning their ecological information content on an annual base.

\section{STUDY MATERIAL \& SiTES}

This dissertation forms a compilation of a number of case studies that include study material from different tree species growing in different tropical regions. Depending on the objectives of the sub-studies a careful selection has been made of stem discs that form a part of the tropical stem-disc collection subsisted by the Department of Crop Sciences, Agronomy in the Tropics, University of Göttingen, Germany. The stem-disc collection at Göttingen University is a unique archive and contains specimens of more than 400 species ( $>75$ families, $>225$ genera). This collection was initiated by Martin Worbes on the base of his extensive number of stem discs (Worbes 1985, 1989, 1999 a,b; Worbes et al. 1992). The collection was augmented with stem discs of several bachelor, master and doctorate studies and scientific cooperations (among others Dezzeo et al. 2003, Fichtler et al. 2003, 2004, Menezez et al. 2003, Raschke 2003, Röll 2010). One important prerequisite for the present study was that all previous studies on this material have dealt with the annual nature of growth rings. In addition a variety of information on the respective tree individuals as well as site conditions was available (e.g. Dezzeo et al 2003, Fichtler et al. 2003, 2004, Raschke 2003, Ortiz et al. 2006, Schöngart et al. 2006, Worbes 1985, 1989, 1999 a,b, Worbes et al. 1992, Staschel et al. 1996). 
The collection includes material from various tropical ecosystems (Figure 1) ranging from species growing in humid lowland rainforest (Costa Rica) to arid savannah woodlands (Namibia). The most humid site showed more than $4000 \mathrm{~mm}$ rainfall per year and a short dry period of about two weeks in average. The driest site showed less than $500 \mathrm{~mm}$ rainfall per year and a dry period of up to seven months. Also areas subject to pronounced flooding periods are represented with mean duration of these events varying between 13 to 27 weeks. In the following chapters every sub-sample set used is described in detail together with an overview of the site conditions, respectively. 


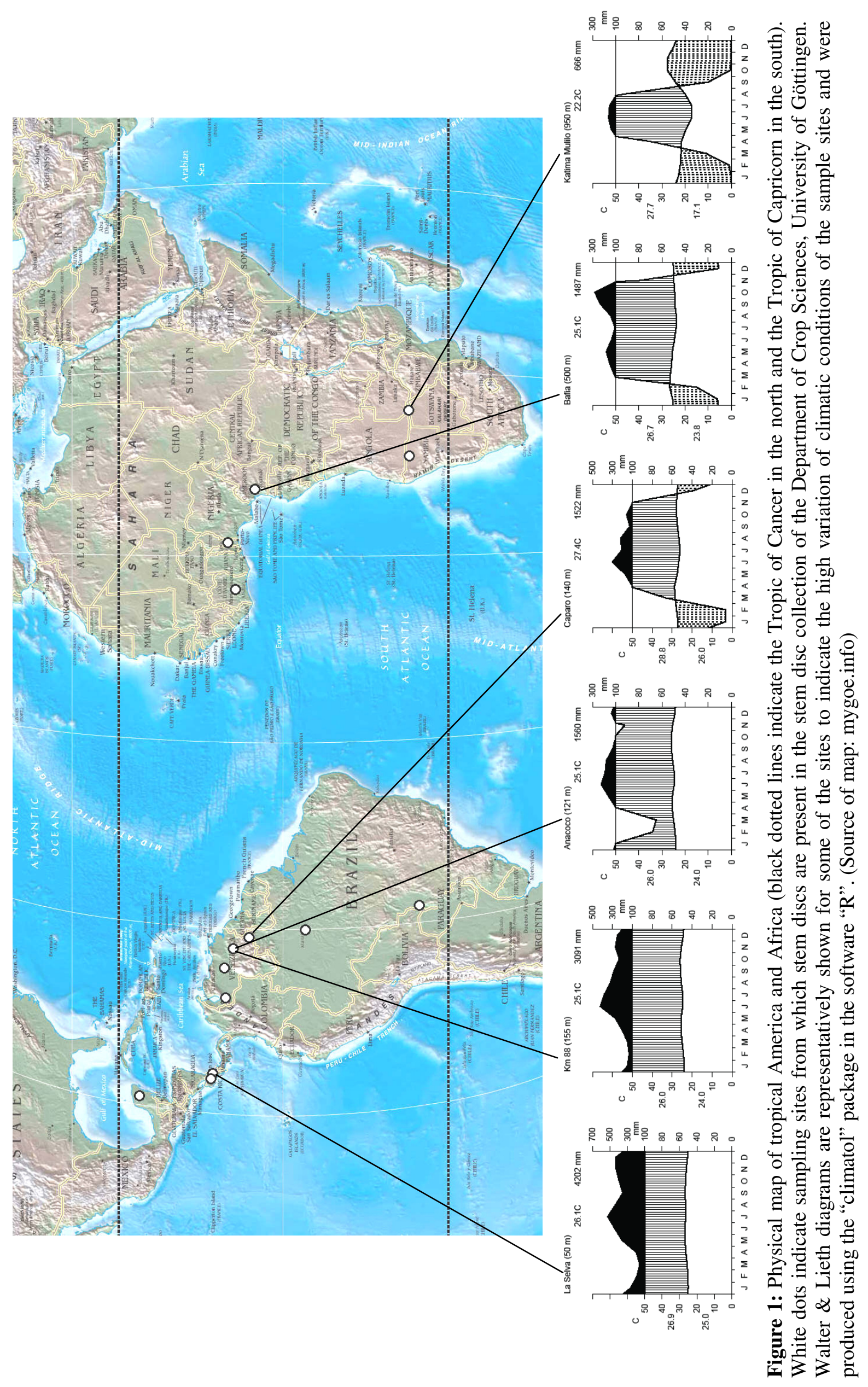




\section{OUTLINE OF THIS DISSERTATION}

CHAPTER 1 provides a general introduction to the topic and research questions of this dissertation.

CHAPTER 2 assesses the importance of wood anatomy for tropical tree ring analytical studies on the example of trees from the Amazonian floodplain forests. In this chapter the anatomical background of the visibility of tree rings is explained and an extended overview on the wood anatomy and tree-ring structures of the stem of many tree species is given.

CHAPTER 3 exposes the application of 'classic temperate' dendrochronological methods at a tropical site, where precipitation is the delimiting factor on tree growth. The dendroclimatic potential of two dominant species from tropical dry forests in northern Namibia was examined. Both species (Burkea africana, Hook, and Pterocarpus angolensis, DC) were sampled at two sites (ca. $900 \mathrm{~km}$ apart). Climate-growth relations were studied by examination of tree ring chronologies in relation to several climatic variables, including ENSO indices.

CHAPTER 4 examines the variability of intra- and inter-annual carbon isotopic pattern in several tree species from various tropical climates. The $\delta^{13} \mathrm{C}$ values of samples of 12 broadleaved trees (seven species) from various paleo- and neotropical sites along a climatic moisture gradient was investigated. The inter-annual variability between species and sites was studied. Further the relationship between $\delta^{13} \mathrm{C}$ and precipitation time series was analyzed.

CHAPTER 5 explores different wood anatomical variables across taxa and climatic zones on the base of individual tree rings. On a macroscopic scale different vessel parameters (e.g. diameter, area and frequency) as well as the relative amount of vessel, parenchyma and fibre cross-sectional area occupied were measured. To reveal information on the spatial and temporal variation of these variables wood anatomical characteristics were related to the phylogenetic groups, different site conditions and individual plant performance.

CHAPTER 6 summarizes the main results of this dissertation and provides a general conclusion. 


\section{REFERENCES}

Avissar, R. \& D. Werth. 2005: Global Hydroclimatological Teleconnections Resulting from Tropical Deforestation. J. Hydrometeor, 6: 134-145.

Bonan, G.B. 2008. Forests and Climate Change: Forcings, Feedbacks, and the Climate Benefits of Forests. Science 320: 1444-1449.

Bräuning, A. 2011. Editorial note for the special issue on 'Tropical Dendroecology'. Trees Structure and Function 25: 1-2.

Brienen, R.J.W. \& P.A. Zuidema. 2006a. Lifetime growth patterns and ages of Bolivian rain forest trees obtained by tree ring analysis. Journal of Ecology 94: 481-493.

Brienen, R.J.W.\& P.A. Zuidema. 2006b. The use of tree rings in tropical forest management: Projecting timber yields of four Bolivian tree species. Forest Ecology and Management 226: 256-267.

Brienen, R.J.W., E. Lebrija-Trejos, M. van Breugel, E.A. Perez-Garcia, F. Bongers, J.A. Meave \& M. Martinez-Ramos. 2009. The Potential of Tree Rings for the Study of Forest Succession in Southern Mexico. Biotropica 41: 186-195.

Büntgen, U., W.Tegel, K. Nicolussi, M. McCormick, D. Frank, V. Trouet, J.O. Kaplan, F. Herzig, K.-U. Heussner, H. Wanner, J. Luterbacher \& J. Esper. 2011. 2500 Years of European Climate Variability and Human Susceptibility. DOI: 10.1126/science.1197175.

Callado, C.H., S.J.D. Neto, F.R. Scarano \& C.G. Costa. 2001. Periodicity of growth rings in some flood-prone trees of the Atlantic Rain Forest in Rio de Janeiro, Brazil. Trees Structure and Function 15:492-497.

Caspersen J.P., S.W. Pacala, J.C. Jenkins, G.C. Hurtt, P.R. Moorcroft \& R.A. Birdsey. 2000. Contributions of land-use history to carbon accumulation in U.S. forests. Science 290:1148-1151.

Chave, J., D. Coomes, S. Jansen, S.L. Lewis, N.G. Swenson \& A.E. Zanne. 2009. Towards a worldwide wood economics spectrum. Ecology Letters 12: 351-366.

Clark, D.A. \& D.B. Clark. 2011. Assessing Tropical Forests' Climatic Sensitivities with Long-term Data. Biotropica 43: 31-40.

Cook, E.R. 1987. The decomposition of tree-ring series for environmental studies. Tree-ring bulletin 47: 37-59.

Coster, C. 1927. Zur Anatomie und Physiologie der Zuwachszonen- und Jahresringbildung in den Tropen. Annales Jardin Botanica Buitenzorg 37: 49-160. 
Couralet, C., F.J. Sterck, U. Sass-Klaassen, J. Van Acker \& H. Beeckman. 2010. SpeciesSpecific Growth Responses to Climate Variations in Understory Trees of a Central African Rain Forest. Biotropica 42: 503-511.

Dezzeo, N., M. Worbes, I. Ishii \& R. Herrera. 2003. Annual tree rings revealed by radiocarbon dating in seasonally flooded forest of the Mapire River, a tributary of the lower Orinoco River, Venezuela. Plant Ecology 168: 165-175.

Dixon, R.K., S.R. Brown, A. Houghton, A.M. Solomon, M.C. Trexler \& J. Wisniewski. 1994. Carbon pools and flux of global forest ecosystems. Science 263: 185-190.

Esper J, E.R. Cook \& F.H. Schweingruber. 2002. Low-Frequency Signals in Long Tree-Ring Chronologies for Reconstructing Past Temperature Variability. Science 295: 22502253.

Feeley, K.J., S.J. Wright, M.N.N. Supardi, A.R. Kassim \& S.J. Davies. 2007. Decelerating growth in tropical trees. Ecology Letters 10: 461-469.

Fichtler, E., D.A. Clark \& M. Worbes. 2003. Age and long-term growth of trees in an oldgrowth tropical rain forest, based on analyses of tree rings and 14C. Biotropica 35: 306-317.

Fichtler, E., V. Trouet, H. Beeckman, P. Coppin, \& M. Worbes. 2004. Climate signals in tree rings of Burkea africana and Pterocarpus angolensis from semiarid forests in Namibia. Trees - Structure and Function 18: 442-451.

Field, C.B., M.J. Behrenfeld, J.T. Randerson. \& P. Falkowski. 1998. Primary production of the biosphere: integrating terrestrial and oceanic components. Science 281: 237-240.

Gourlay, I.D. 1995. Growth ring characteristics of some African Acacia species. Journal of Tropical Ecology 11:121-140.

Groombridge, B. \& M.D. Jenkins. 2003. World Atlas of Biodiversity. Earth's Living Resources in the 21st Century. University of California. Berkeley, Los Angeles, London.

Houghton, R.A. 2007. Balancing the Global Carbon Budget. Annu. Rev. Earth Planet. Sci. $35: 313-47$

Lewis, S.L., O.L. Phillips, T.R. Baker, J. Lloyd, Y. Malhi, S. Almeida, N. Higuchi, W.F. Laurance, D.A. Neill, J.N.M. Silva, J. Terborgh, A.T. Lezama, R.V. Martinez, S. Brown, J. Chave, C. Kuebler, P.N. Vargas. \& B. Vinceti. 2004. Concerted changes in tropical forest structure and dynamics: evidence from 50 South American long-term plots. Phil. Trans. Roy Soc. B 359: 421-436. 
Mann, M.E., C.M. Ammann, R.S. Bradley, K.R. Briffa, T.J. Crowley, M.K. Hughes, P.D. Jones, M. Oppenheimer, T.J. Osborn, J.T. Overpeck, S. Rutherford, K.E. Trenberth \& T.M.L. Wigley. 2003. On Past Temperatures and Anomalous Late $20^{\text {th }}$ Century Warmth. Eos 84: 256-258.

Menezes, M., U. Berger \& M. Worbes. 2003. Annual Growth Rings and long-term Growth Patterns of Mangrove Trees from the Braganca Peninsula, Northern Brazil. Wetlands Ecology and Management 11: 233-242.

Montagini, J. \& C.F. Jordan. 2005. Tropical Forest Ecology. The basis for conservation and management. Springer Berlin, Heidelberg.

Olson, D.M., E. Dinerstein, E.D. Wikramanayake, N.D. Burgess, G.V.N. Powell, E.C. Underwood, J. D'Amico, I. Itoua, H.E. Strand, J.C. Morrison, C.J. Loucks, T.F. Allnutt, T.H. Ricketts, Y. Kura, J.F Lamoreux, W.W. Wettengel, P. Hedao \& K.R. Kassem. 2001. Terrestrial Ecoregions of the World: A New Map of Life on Earth. Bioscience 51: 933-938.

Ortiz, J., L. Hernández \& M. Worbes. 2006. Crecimiento radial de Tachigali y Terminalia en bosques de tierra baja al sureste de Venezuela. Acta Bot Ven 29: 211-234.

Poorter, L. \& K. Kitajima. 2007. Carbohydrate storage and light requirements of tropical moist and dry forest tree species. Ecology 88:1000-1011.

Pumijumnong N. \& D. Eckstein. 2011. Reconstruction of pre-monsoon weather conditions in northwestern Thailand from the tree-ring widths of Pinus merkusii and Pinus kesiya. Trees - Structure and Function 25: 125-132.

Raschke, N. 2003. Baumartendiversität, Struktur und Biomassezuwachs der natürlichen Sekundärvegetation auf ehemaligen Weideflächen in Guancaste, Costa Rica. Staatsexamensarbeit, Tierärtzliche Hochschule Hannover, unpubl.

Röll, A. 2010. Forest characteristics, above ground tree carbon stocks and annual increment of secondary forests in the tropics. Masterthesis University of Göttingen, unpubl.

Rozendaal D.M.A. \& P.A. Zuidema. 2011. Dendroecology in the tropics: a review. Trees Structure and Function 25:3-16.

Schöngart, J. 2008. Growth-Oriented Logging (GOL): A new concept towards sustainable forest management in Central Amazonian varzea floodplains. Forest Ecology and Management 256: 46-58.

Schöngart J., M.T.F. Piedade, S. Ludwigshausen, V. Horna \& M. Worbes. 2002. Phenology and stem-growth periodicity of tree species in Amazonian floodplain forests. Journal of Tropical Ecology 18: 581-597. 
Schöngart, J., W.J. Junk, M.T.F. Piedade, A. Hüttermann, \& M. Worbes. 2004. Teleconnection between forest growth in the Amazonian floodplains and El NiñoSouthern Oscillation effect. Global Change Biology 10: 683-693.

Schöngart, J., B. Orthmann, K.J. Hennenberg, S. Porembski \& M. Worbes. 2006. Climategrowth relationships of tropical tree species in West Africa and their potential for climate reconstruction. Global Change Biology 12: 1139-1150.

Schöngart, J.; F. Wittmann, M. Worbes, M.T.F. Piedade, H.J. Krambeck \& W.J. Junk. 2007. Management criteria for Ficus insipida Willd. (Moraceae) in Amazonian white-water floodplain forests defined by tree-ring analysis. Annals of Forest Science 64: 657-664.

Schöngart J, F. Wittmann \& M. Worbes. 2010. Biomass and NPP of Central Amazonian floodplain forests. In: Junk, W.J., M.T.F Piedade, F. Wittmann, J. Schöngart, P. Parolin (eds). 2010. Central Amazonian floodplain forests: ecophysiology, biodiversity, and sustainable management. Springer, Berlin/Heidelberg/New York.

Stahle, D.W., P.T. Mushove, M.K Cleaveland, F. Roig \& G.A. Haynes. 1999. Management implications of annual growth rings in Pterocarpus angolensis from Zimbabwe. Forest Ecology and Management 124:217-229.

Schweingruber, F.H. 1996. Tree Rings and Environment. Dendroecology. Birmensdorf, Swiss Federal Institute for Forest, Snow and Landscape Research. Berne, Stuttgart, Vienna, Haupt.

Staschel, R., M. Worbes \& A. Roloff. 1996. Wachstumsdynamik von Triplochiton scleroxylon (K. Schum.) in einem halbimmergrünen Naturwald in Kamerun. Verhandlungen der Gesellschaft für Ökologie 26: 183-188.

Trouet, V., P. Coppin \& H. Beeckman. 2006. Annual growth ring patterns in Brachystegia spiciformis reveal influence of precipitation on tree growth. Biotropica 38: 375-382.

Trouet, V., J. Esper, N.E. Graham, A. Baker, J.D. Scourse \& D.C. Frank. 2009. Persistent Positive North Atlantic Oscillation Mode Dominated the Medieval Climate Anomaly. Science 324: 78-80.

Vaganov, E.A., M.K. Hughes \& A.V. Shashkin. 2006. Growth Dynamics of Conifer Tree Rings - Images of Past and Future Environments. Ecological Studies 183.

Verheyden, A., J.G. Kairo, H. Beeckman \& N. Koedam. 2004. Growth rings, growth ring formation and age determination in the mangrove Rhizophora mucronata. Annals of Botany 94:59-66.

Wimmer, R. 2002. Wood anatomical features in tree-rings as indicators of environmental change. Dendrochronologia 20: 21-36. 
Worbes, M. 1985. Structural and other adaptations to long-term flooding by trees in Central Amazonia. Amazoniana 9: 459-484.

Worbes, M. 1989. Growth rings, increment and age of trees in inundation forests, savannahs and a mountain forest in the Neotropics. IAWA Bull. n.s. 10: 109-122.

Worbes, M. 1995. How to measure growth dynamics in tropical trees. A review. IAWA Journal 16: 337-351.

Worbes, M. 1996. Rhythmisches Wachstum und anatomisch-morphologische Anpassungen an Lebensstrategien von Bäumen in zentralamazonischen Überschwemmungswäldern. Mitt. Deutsche Dendrologische Gesellschaft 82: 155-172.

Worbes, M. 1999a. Annual growth rings, rainfall dependent growth and long-term growth patterns of tropical trees from the Forest Reserve Caparo in Venezuela. Journal of Ecology 87. 391-403.

Worbes, M. 1999b. Degradación e historia de la vegetación boscosa de la Gran Sabana. Scientia Guaianae 9: 84-107.

Worbes, M. 2002. One Hundred Years of Tree ring Research in the Tropics - A Brief History and an Outlook to Future Challenges. Dendrochronologia 20: 217-231.

Worbes, M. \& W.J. Junk. 1999. How old are Tropical Trees? The persistence of a myth. IAWA Journal 20: 255-260.

Worbes, M., H. Klinge, J.D. Revilla \& C. Martius. 1992. On the dynamics, floristic subdivision and geographical distribution of várzea forests in Central Amazonia. Journal of Vegetation Science 3: 553-564.

Worbes, M., R. Staschel, A. Roloff \& W.J. Junk. 2003. Tree Ring Analysis Reveals Age Structure, Dynamics and Wood Production of a Natural Forest Stand in Cameroon. Forest Ecology and Management 173: 105-123.

Zuidema, P.A., M. Vlam \& P.D. Chien. 2011. Ages and long-term growth patterns of four threatened Vietnamese tree species. Trees - Structure and Function 25: 29-38. 


\title{
2 Wood Anatomy And Tree-Ring Structure AND Their IMPORTANCE FOR TROPICAL DENDROCHRONOLOGY
}

\author{
MARTIN WORBES \& ESTHER FICHTLER
}

PUBLISHED IN:

Junk, W.J.; Piedade, M.T.F.; Wittmann, F.; SchÖngart, J.; PArolin, P. (Eds.), 2010. AMAZONIAN FLOODPLAIN FORESTS: ECOPHYSIOLOGY, BIODIVERSITY AND SUSTAINABLE MANAGEMENT. SPRINGER, HeIDELBERG 615P.

\section{AbStract}

In Amazonian floodplain forests, the flood pulse results in an alternating aquatic and terrestrial phase per year. Consequentially, trees react with cambial dormancy, resulting in differing wood anatomical structures that appear as rings in the cross-section of the trees stem. Annual tree-ring patterns represent a reliable basis that can be used in various ways to gain information on historical growth rates, tree age, and past environmental conditions. In the following chapter, the anatomical background of the visibility of tree rings will be explained and an overview over the wood anatomy and tree-ring structures of the stem of many tree species in the igapó and várzea will be given. Most species in the várzea (77\%) show well defined rings around the entire cross-section; most species in the igapó (60\%) show distinct rings but they are not visible around the entire cross-section or are generally ill-defined; species with poor and barely visible boundaries originate from the igapó. Despite the large variability of tree rings from tropical regions, their annual nature could be proven for many tree species. This opens the possibility to widely apply tree-ring analytical studies in the tropics. 


\section{INTRODUCTION}

Trees all over the world face periodically unfavorable growing conditions and consequentially respond with cambial dormancy due to the annual variation of either precipitation (drought stress), temperature (frost) or flooding (water stress). This results in the reduction of radial growth for days or months and in differing wood anatomical structures that appear as rings in the cross-section of the tree stems. Rings are annual, if the triggering climate factors, such as a dry period in most parts of the tropics, occur once a year (Worbes 1995). Understanding the past and current dynamics of the world's tropical rain forests is an important current challenge for ecologists. Annual tree-ring patterns represent a reliable basis that can be used in various ways to gain information on forest dynamics (Worbes et al. 1992, Brienen and Zuidema 2006), tree ages (Worbes and Junk 1999) growth rates, climate reconstructions (Worbes, 1999; Schöngart et al. 2004) to estimate management criteria (Schöngart 2010) and changes in the C-stocks of above-ground coarse wood biomass (Schöngart et al. 2010).

In Amazonian floodplain forests, flooding (lasting up to several months) and water level fluctuations result in annually alternating aquatic and terrestrial phases. During the aquatic phases of the soil, anoxic conditions hinder root respiration and water uptake. This induces leaf shedding in many tree species (cf. Parolin et al. 2010) followed by cambial dormancy (Schöngart et al. 2002). The reduction of growth at the end of the growing period leads in many species to a visible change in the formation and differentiation of wood cells. In most obvious cases a clear differentiation is possible into 'earlywood' cells, formed when the growing period starts, and 'latewood' cells, formed later in or at the end of the growing period. The first hint to the annual nature of these growth zones was given by Gessner (1968), it was proven by means of radiocarbon dating (Worbes 1984) and is the basis for a wide range of applications.

In the following chapter, an overview over the wood anatomy and tree-ring structures of the stem of many tree species in the igapó and várzea will be given. The described woodanatomical structures are to be found in tree species throughout the globe as well. Therefore this chapter is to exemplify the general characteristics of tropical tree-ring structures.

Nomenclature follows APGII, authors of plant names are given in Table 1. In the figures, wood structure is shown in the growing direction from the bottom-up, arrows indicate tree-ring boundaries. 


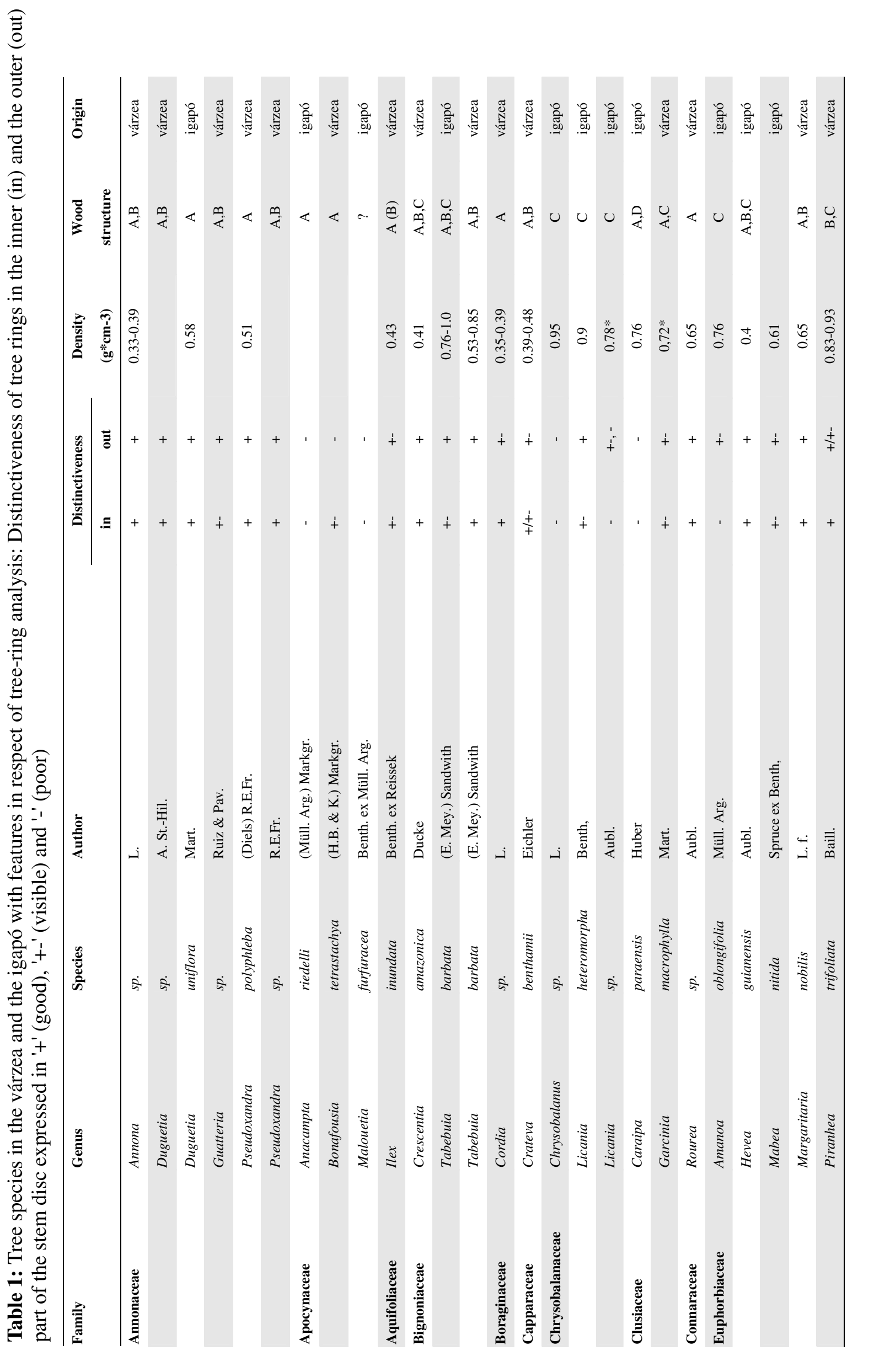




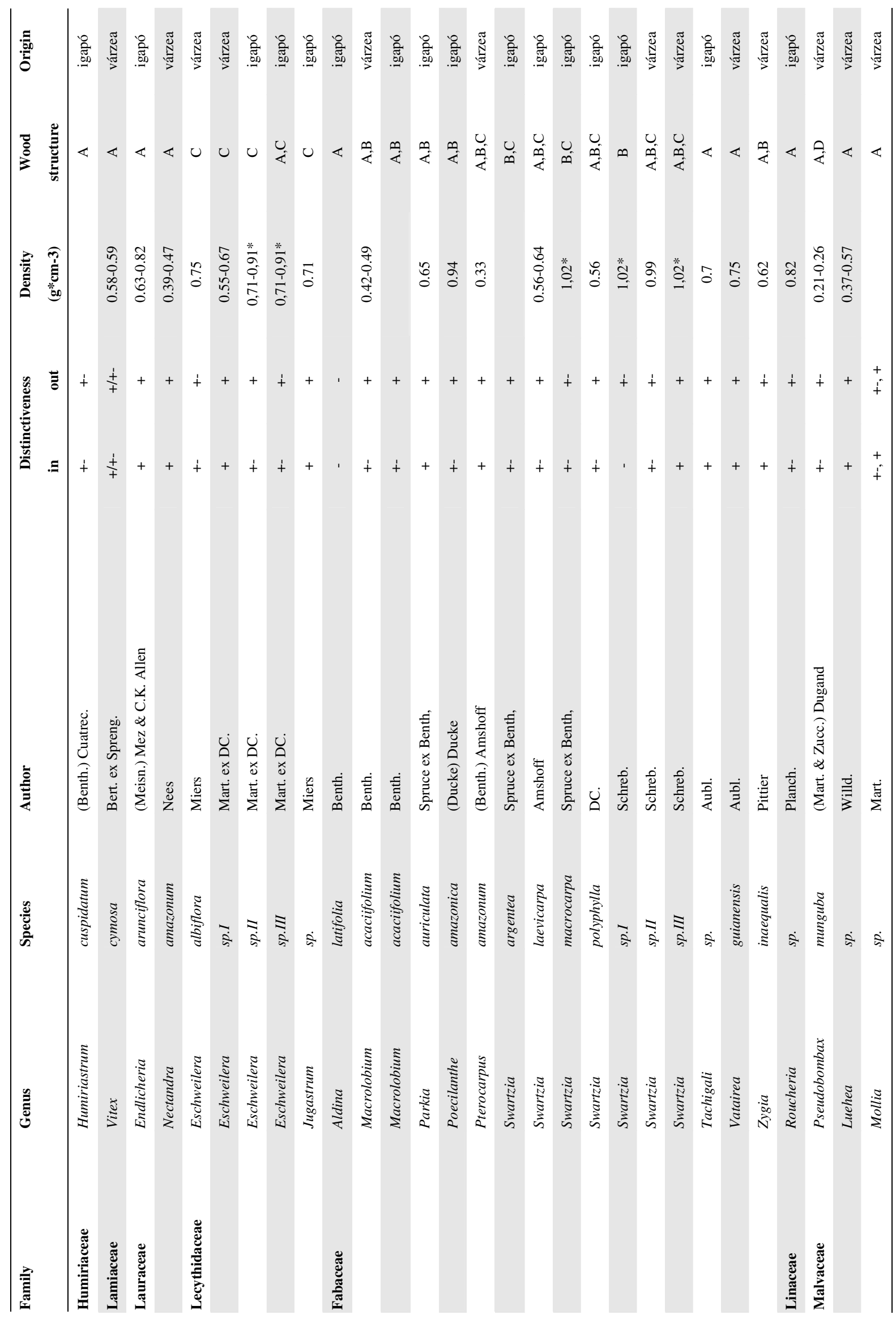




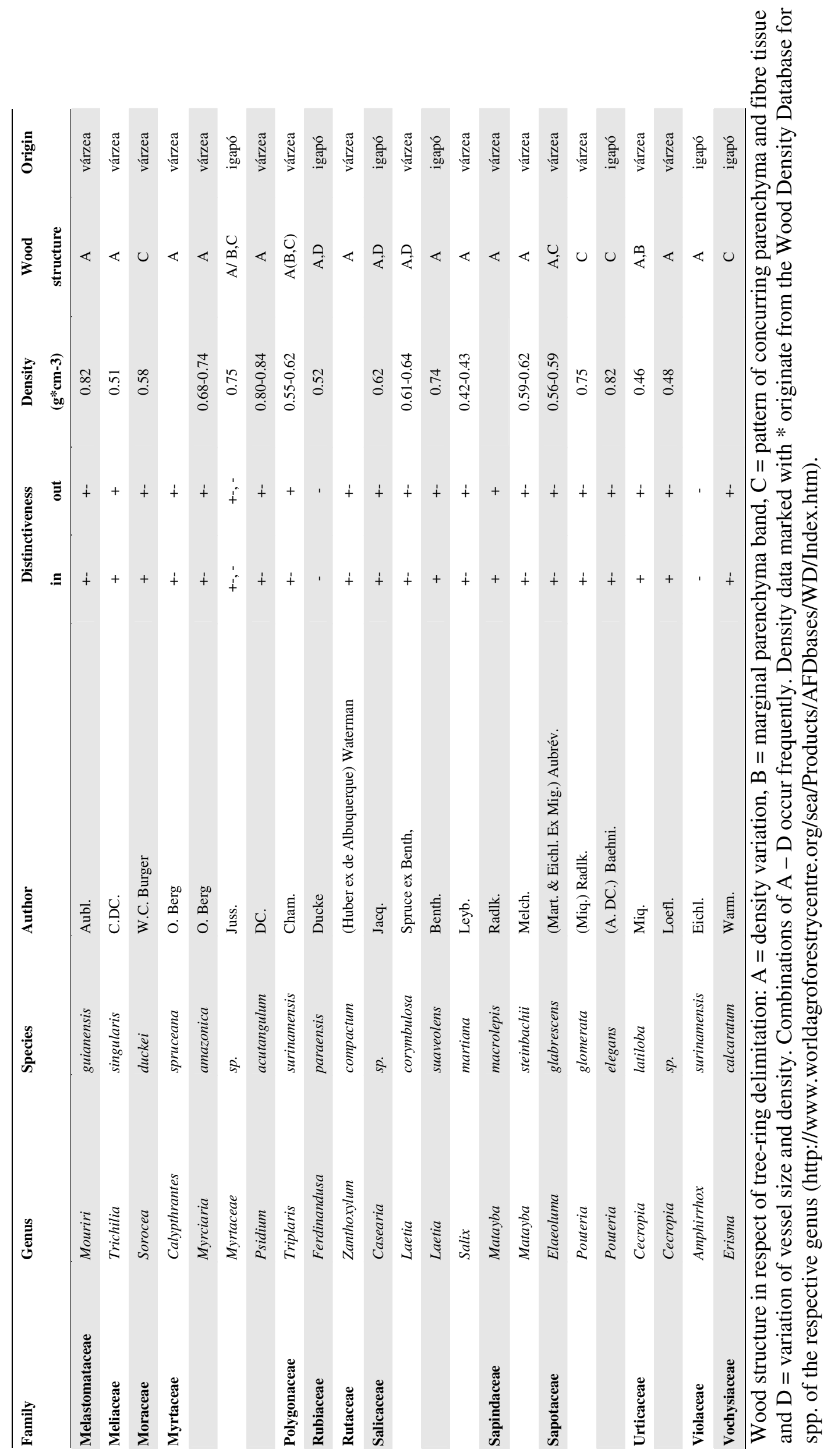




\section{Anatomical Classification of Tree-Ring Structures}

Macroscopically apparent growth structures become visible as rings in a cross-section as light/dark zones or bands on sanded discs. Here, the anatomical background of the visibility will be explained. In general, different colors within one growth zone can be traced back to the variation in wood density, where the dark zones show a higher density, which is attributed to fibre cells with shortened radial diameters and thickened walls. This is clearly visible in coniferous wood (Schweingruber 2001), but also in several broad-leaf families in the tropics. The high diversity of tropical woody species however is reflected in a high diversity of growth-zones structures, formed as a composition of different vessel, fibre and parenchyma characteristics. These can be ordered into almost 40 different classes (Carlquist 1988). Nevertheless, for a more applicable system, the authors follow Coster $(1927,1928)$ and reduce the number of classes to four basic tree-ring types (Worbes 1985):

A. Most common is a tree-ring boundary consisting of one or several rows of fibres with shortened radial diameter and thickened walls (Figure 1), resulting in density variations. This type can be found in almost all the investigated plant families.

B Also common, especially in the Fabaceae, are boundaries with uni- or multi-rowed marginal bands of axial parenchyma cells, often filled with substances, of a very light appearance (Figure 2).

C In several species, periodically recurring parenchyma and fibre bands of different widths result in a certain pattern delineating the boundary of the tree ring (Figure 3). For Sapotaceae, Lecythidaceae and Moraceae in particular, a broad band of fibre cells marks the beginning of the ring. Adjacent to this, bands of parenchyma alternate with bands of fibres, usually becoming narrower toward the end of a ring.

D Often described for temperate tree species, but also occurring in tropical species, this type is characterized by varying frequency and diameter of vessels within a ring (Figure 4). Often, this type is characterized by many and/or large vessels at the beginning of the ring, but other species show the largest vessels in the middle of the ring. 

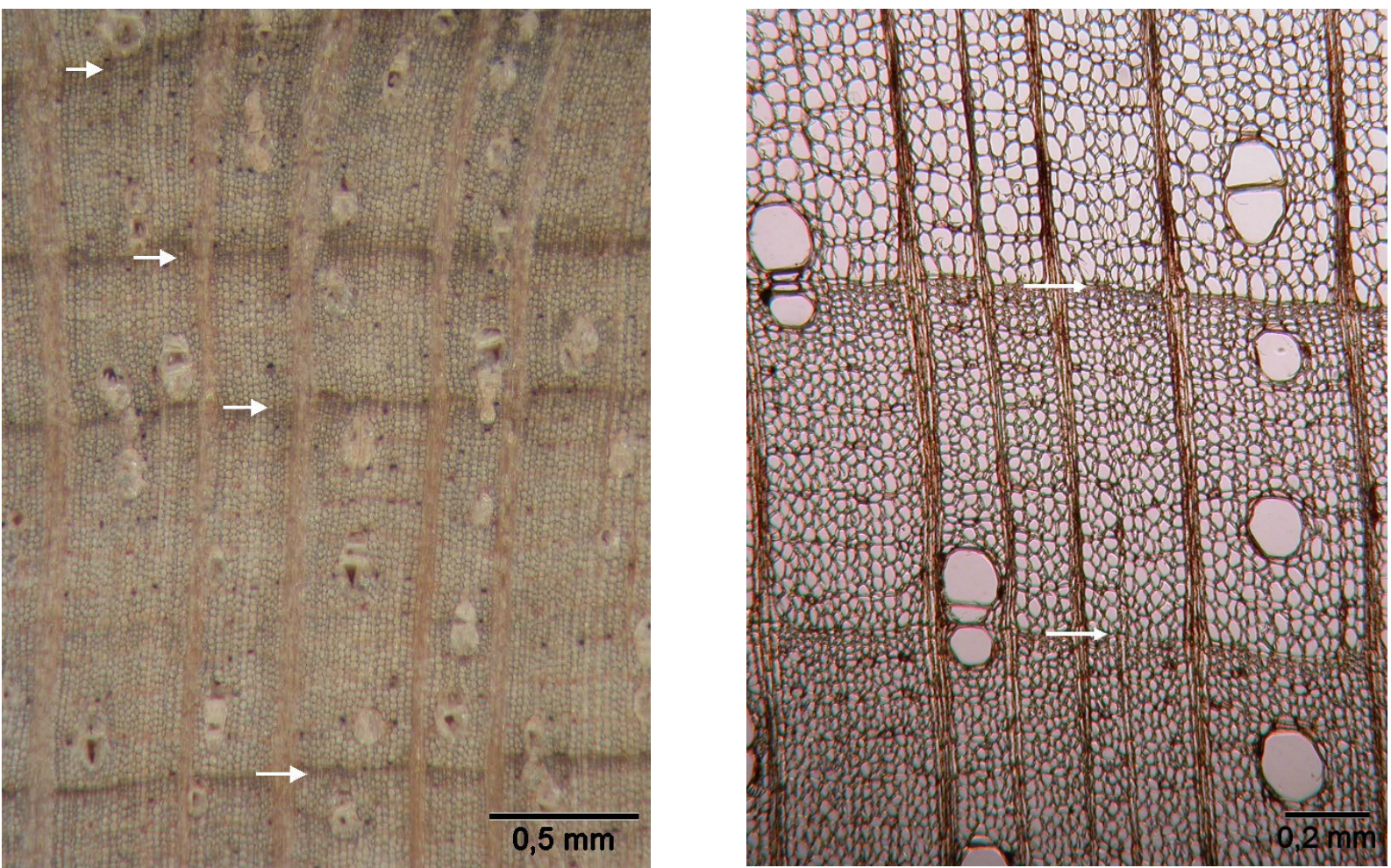

Fig. 1 Tree-ring type A, density variations in the wood structure of Annona sp., Annonaceae, in the várzea: (left) macroscopic and (right) microscopic cross-section
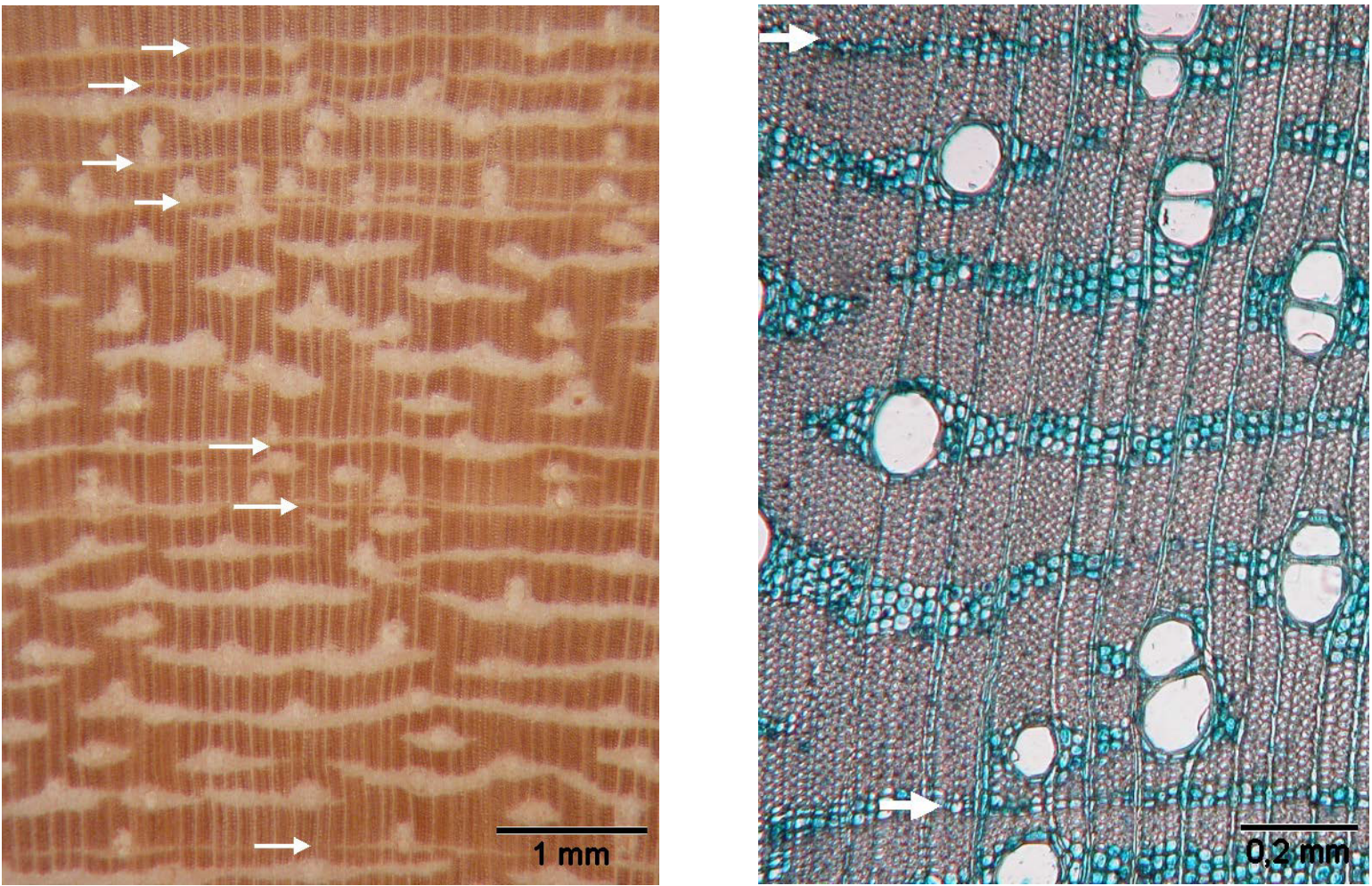

Fig. 2 Tree-ring type B, marginal parenchyma band in the wood structure of Swartzia argentea, Fabaceae, in the igapó, (left) macroscopic and (right) microscopic cross-section 

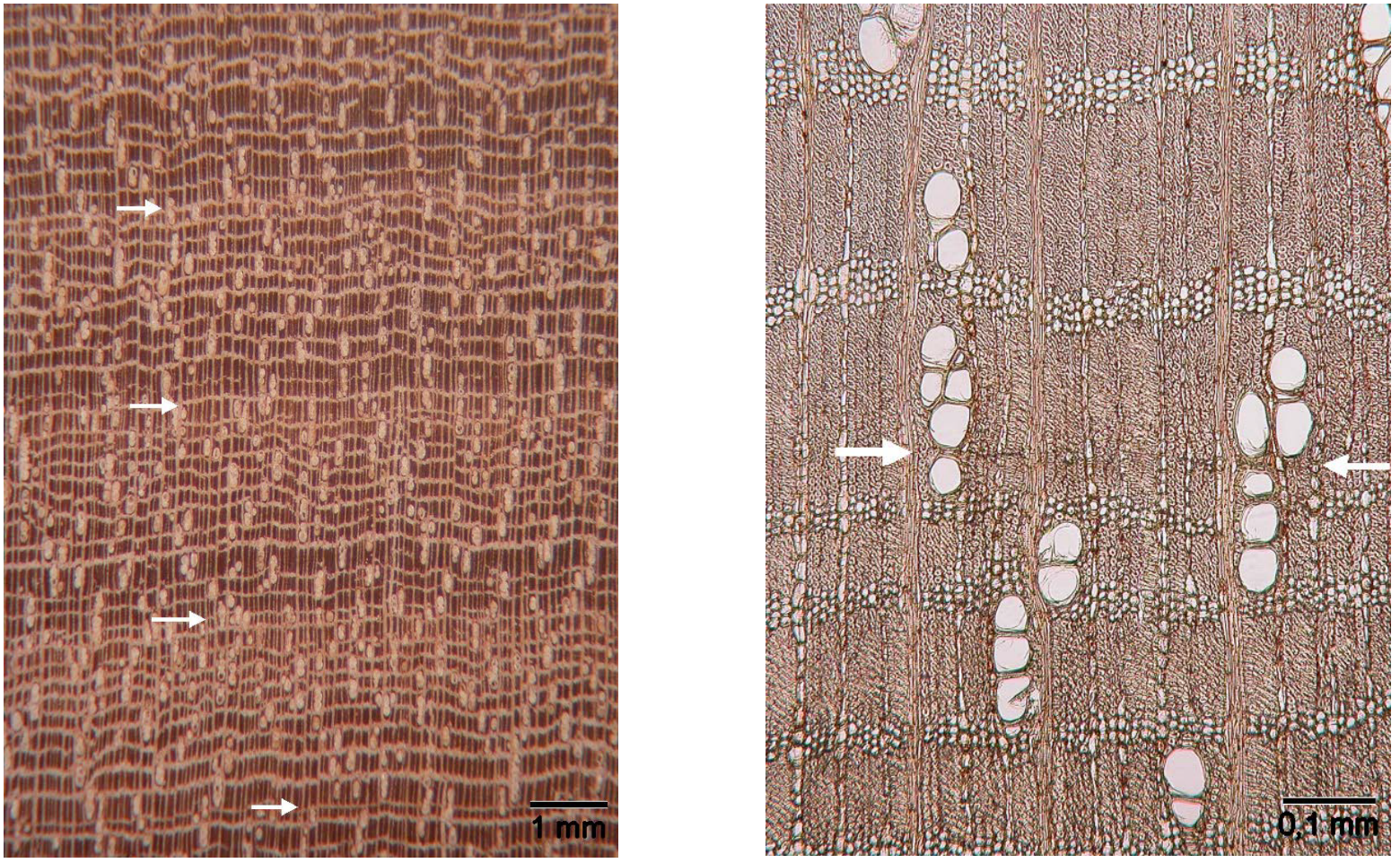

Fig. 3 Tree-ring type C, patterns of parenchyma and fibre bands, in the wood structure of Pouteria glomerata, Sapotaceae, in the várzea, (left) macroscopic and (right) microscopic cross-section
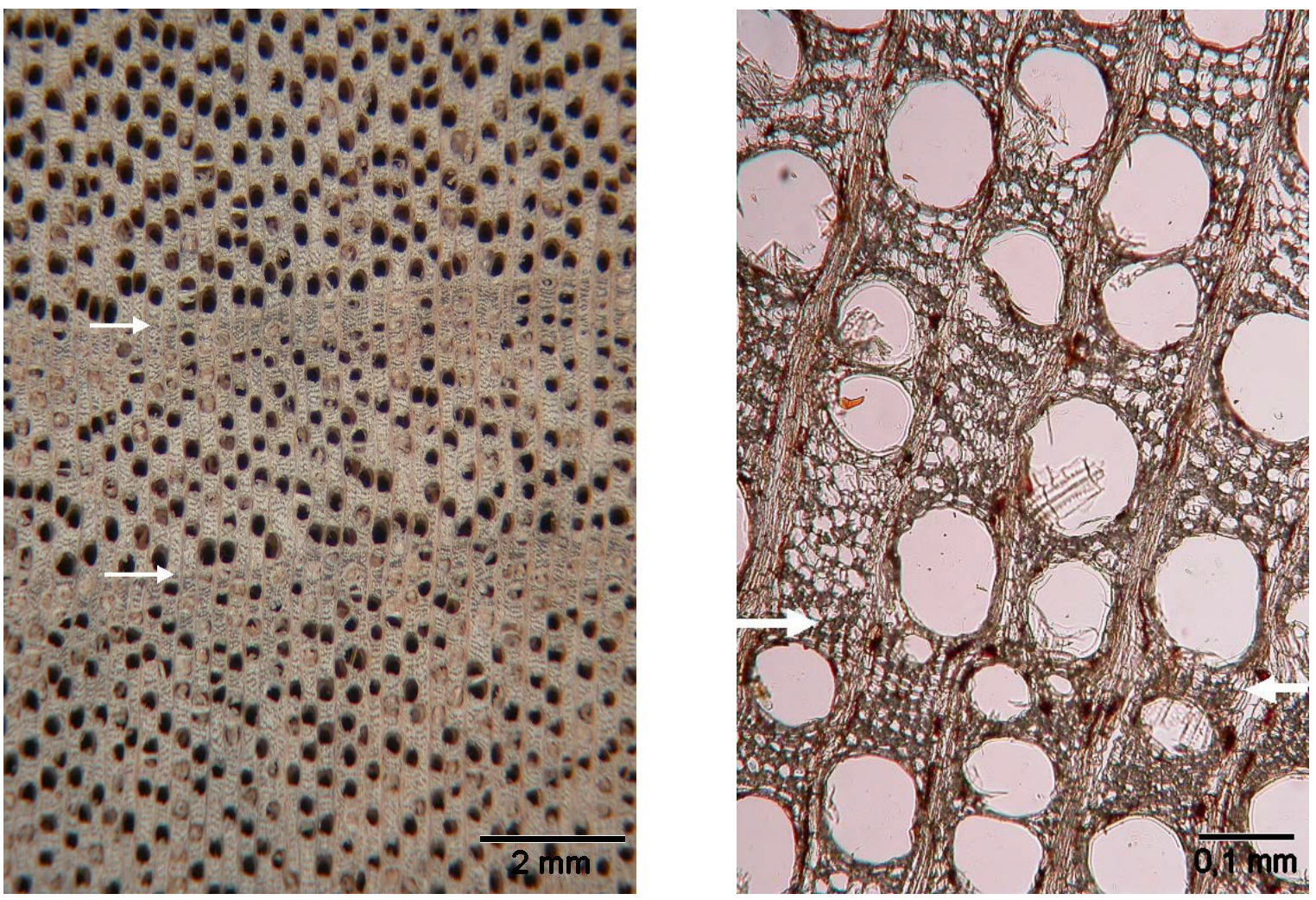

Fig. 4 Tree-ring type D, variation in vessel density/size in the wood structure of Pseudobombax munguba, Bombacaceae, in the várzea, (left) macroscopic and (right) microscopic cross-section 
The characteristics described in A - D often occur in various combinations. Thereby combinations can co-occur within the same ring. An example is given by the rings of an individual of Macrolobium acaciifolium (Figure 5) which combines three ring characteristics: The variation of cell wall thickness and cell lumen diameter results in a clear shift from light earlywood to dark latewood, the variation in vessel size and density from few small vessels at the beginning of the ring merge to frequent large vessels toward the end of the ring. Finally, a light terminal parenchyma band highlights the boundary. In other cases, different rings within the same individual can show extreme dissimilar characteristics. In an individual of Salix martiana (Figure 6) for instance, two consecutive rings show a complete different appearance: The first ring is delineated only by a multi-rowed band of latewood fibres, while the second ring is characterized by the variation of vessel size and frequency, i.e. a broad band of many large vessels at the beginning of the ring.

To use growth patterns for tree-ring studies, a successful determination of tree-ring boundaries throughout a sample is required. To detect all boundaries within a sample, it is therefore essential to consider changes in the general pattern of the growth structure rather than searching for a single specific character delineating a tree ring.

Fig. 5 Tree-ring boundaries of Macrolobium acaciifolium, Fabaceae, in the várzea showing a combination of tree-ring types $\mathrm{A}, \mathrm{B}$ and $\mathrm{C}$ in the same rings

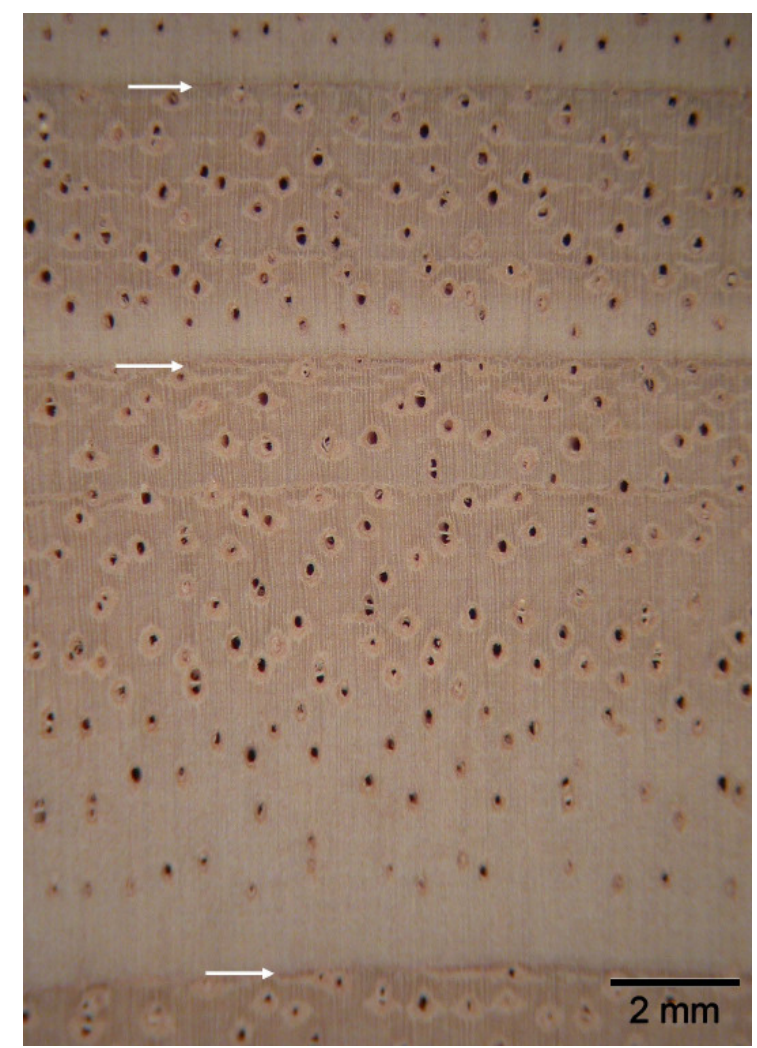


Fig. 6 Differing tree-ring boundaries of Salix martiana, Salicaceae, in the várzea showing variations in cell wall thickness (Type A) in one ring (below) and variations in vessel density/size (Type D) in a consecutive ring

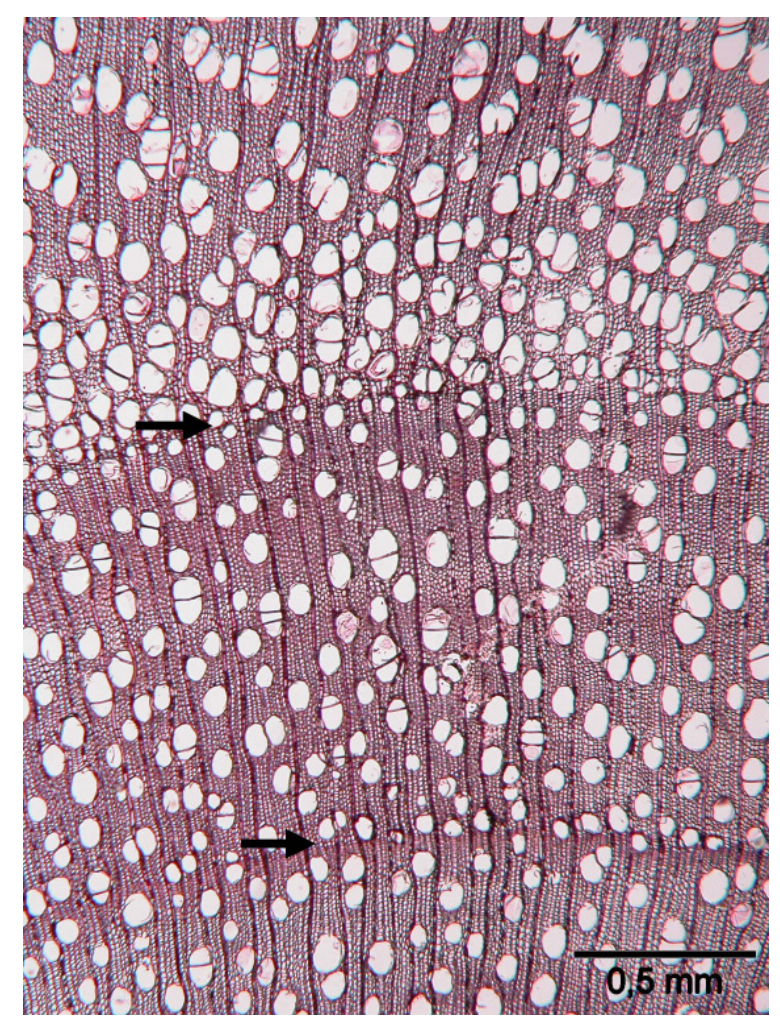

\section{Macroscopical Variability of The Visibility of Rings Within Species AND INDIVIDUALS OF TREES IN THE IGAPÓ AND VÁRZEA}

In a study on structural and other adaptations to long-term flooding by trees in the igapó and várzea (Worbes 1985), cross-sections from almost all tree species of test plots were taken. The analysis was done with respect to the presence and formation of growth rings and showed that all tree species investigated have well-defined growth rings, that can be ascribed to one or more of the before characterized growth-rings types A-D (cf. table 1). However, numerous examples show that even distinct tree-ring boundaries underly a broad variability within a species and among individuals: Sometimes ring boundaries are ill-defined near the center of the disc, whereas they are quite distinct in the outer region near the bark (cf. Table 1). Some species form clear ring boundaries in their juvenile stage, later forming either illdefined rings or narrow rings of very few or single cell rows, that can hardly be distinguished.

In certain taxa (e.g. Annonaceae) tree species tend to form wedging rings meaning that tree rings merge due to a failure of cambial activity at certain positions of the stem (Figure 7). An explanation for wedging rings is, for example, a changing light saturation due to changing competition pressure by surrounding trees. This probably leads to differences in the local 
supply of carbohydrates, water, mineral elements and phytohormones (Dünisch et al. 1999). In tree species showing wedging rings, the correct identification of ring boundaries at a single radius is impossible but requires the analysis of stem discs. Nevertheless, within a tree species, individuals with clear concentric rings may occur as well as those with frequently wedging rings. Within a stem disc, rings may tend to wedge only in outer parts, when the tree starts to form buttresses (Figure 8).

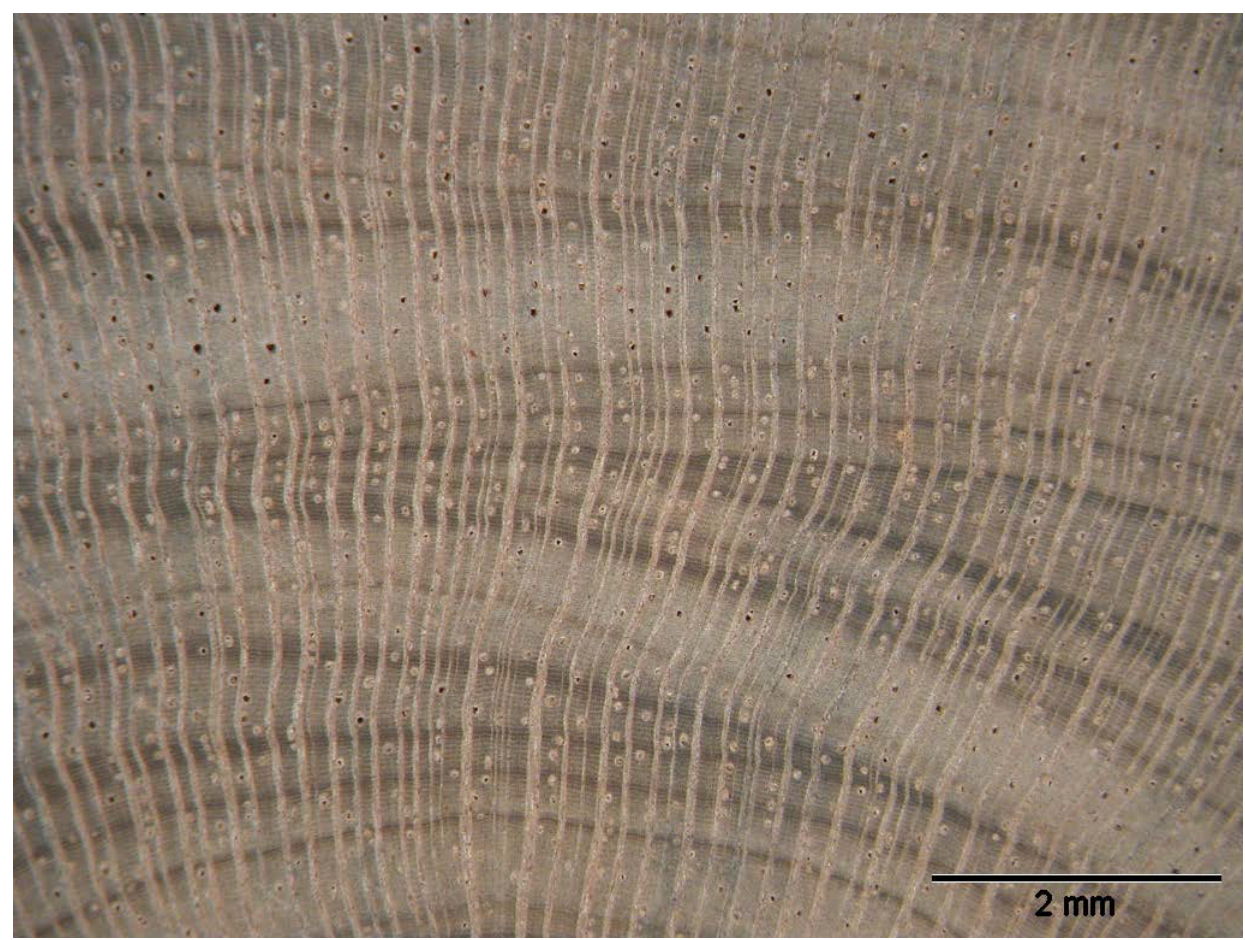

Fig. 7 Section of a disc of Duguetia uniflora, Annonaceae, in the igapó showing multiple wedging rings on various positions of the disc

Fig. 8 Disc of Swartzia polyphylla, Fabaceae, in the igapó showing wedging rings in the outer part due to the formation of buttresses

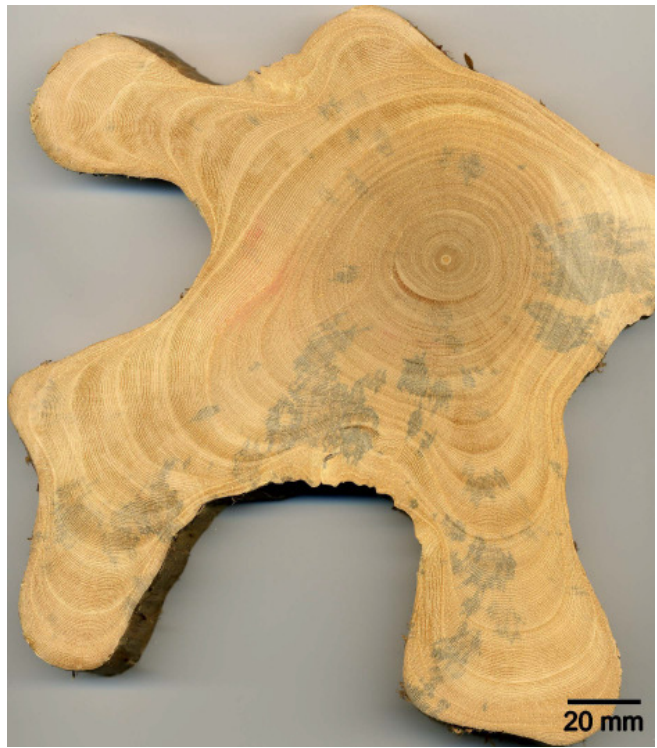


In other species, the identification of tree rings is more difficult, because boundaries may tend to gradually disappear or break-off (Figure 9). Finally, various species show generally ill-defined boundaries, especially under high magnification (Figure 10).

Various species of a family such as Euphorbiaceae, Lecythidaceae or Malvaceae show different characteristics as regards the distinctiveness of tree-ring boundaries. Species of other families (e.g. Lauraceae) show generally rather distinct growth rings. The most diverse formation occurs within the genus Swartzia, although most frequent are observations with wedging or disappearing rings. This genus forms defined tree-ring boundaries in general (Figure 2) but these are not evident over the entire cross section. For many families no concentration in certain categories was noted on the basis of the available wood samples. Three tendencies could be observed: most species in the várzea $(77 \%)$ show well-defined rings around the entire cross-section; most species in the igapó (60\%) show rings that are not visible around the entire cross section or are generally ill-defined; species with poor and barely visible boundaries originate from the igapó.

In general, both floodplain forests produce trees with ring structures suitable for tree-ring analytical studies. Continuous as well as abrupt fluctuations of endogenous and exogenous factors result in structural changes of the wood anatomy and changing tree-ring widths. In dendrochronological studies abrupt changes are of special interest, as these can be used to

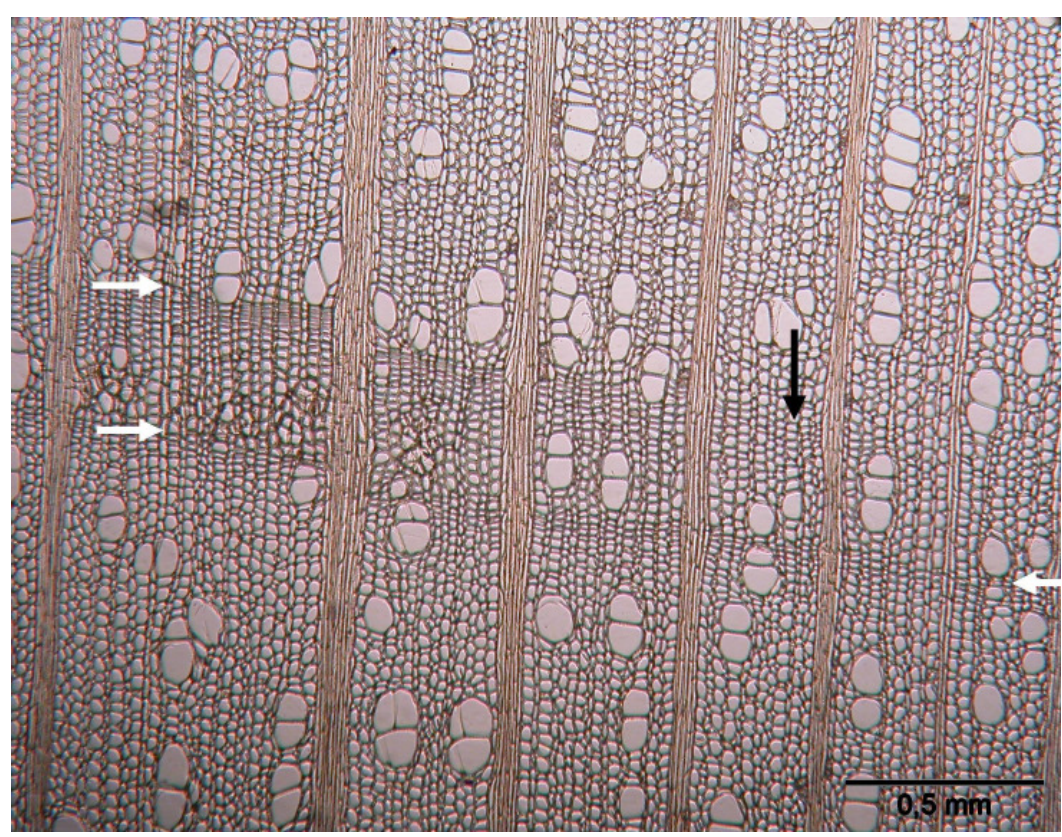

Fig. 9 Break-off of a tree-ring boundary in an individual of Ilex inundata, Aquifoliaceae, in the varzea. On the left side two, on the right side only one tree-ring boundaries are visible (white arrows), the black arrow roughly indicates the area where the boundary is not visible anymore 
date and analyse the impact of certain incidents, such as extreme climatic events or suppression and release effects (Schöngart et al. 2004; Brienen and Zuidema 2006).
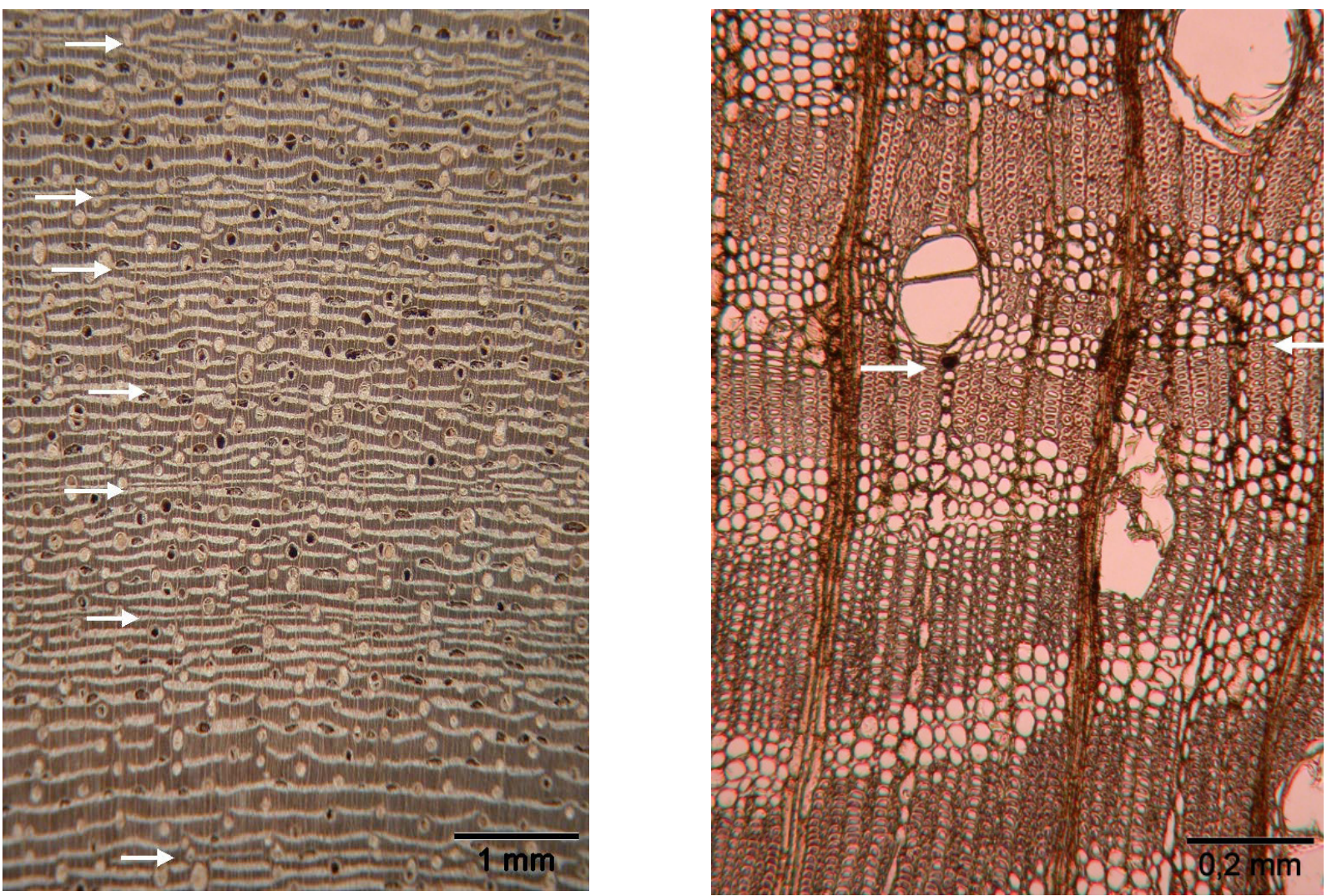

Fig. 10 Wood structure of Erisma calcaratum, Vochysiaceae, in the igapó showing generally illdefined ring boundaries, (left) macroscopic and (right) microscopic cross-section; with increasing magnification the boundaries become more difficult to detect 


\section{Structure and Ecological Function of Xylem Elements in Growth}

\section{ZONES}

Little is known about the relation between ecological function and anatomical structure of wood. The majority of the wood anatomical literature deals with the taxonomic differentiation and seldom offers ecological explanations for differences in structure. In xylem, vessels, fibres and parenchyma accommodate hydraulic conductivity, stability, and storage, respectively. Well documented is only the relation between vessel dimensions and water supply (Baas 1990). At a rough geographical scale, there is a trend that species with small vessels are linked with dry climate conditions, having safety margins against air embolism in dry periods. In many species of floodplain trees vessel size tends to decrease towards the end of the growth zones. This could be a hint for increasing water stress towards the beginning of flooding, when the water conduction from roots to leaves is inhibited by oxygen deficiency in the soil (Worbes 1997).

Large variations occur in the share of parenchyma and fibres, suggesting large variation in storage capacities and mechanical stability. In different species of growth zone type C (cf. Macrolobium acaciifolium in Figure 11) the absence of parenchyma and vessels in a broad band of fibres in the earlywood is obvious. This band is followed by a mixture of parenchyma, vessels and fibre wood in specifically dependent variations. Fink (1982) as well as Dünisch and Puls (2003) observed in different tropical tree species that starch is predominantly stored in axial parenchyma and soluble carbohydrates are mobilized at the beginning of the growing period in support of the formation of new leaves and secondary xylem before the new foliage produces carbohydrates through photosynthesis. That means, that the observed pattern in distribution of axial parenchyma and fibres is not random, but reflects clearly the mechanisms of carbohydrate storage and mobilization as a function of specific phenological behaviour triggered by the dominating and limiting external growth factor. The composition of the xylem, in general, exhibits large variations within and between trees. The image analytical comparison of two individuals of Tabebuia barbata from the várzea and the igapó, respectively, showed that also nutrient availability affects the relative share of parenchyma and fibres: The individual from the igapó showed smaller radial increments $(1,17 \mathrm{~mm})$ compared to the várzea tree $(1,43 \mathrm{~mm})$ and therefore invested more capacity in storage and mobilization by forming a large amount of axial $(34,81 \%)$ and radial $(11,23 \%)$ parenchyma compared to fibre cells $(46,23 \%)$. That may help a tree to survive periods of low resource levels and thereby compensate low nutrient availability in the igapó 
(Schöngart et al. 2005). Given that fibre cells are the major costs of making xylem, it is not astonishing that the individual from the nutrient rich várzea can invest most in fibre cells $(53,38 \%)$ and, as there is less need, fewer in axial $(28 \%)$ and radial $(7,96 \%)$ parenchyma.
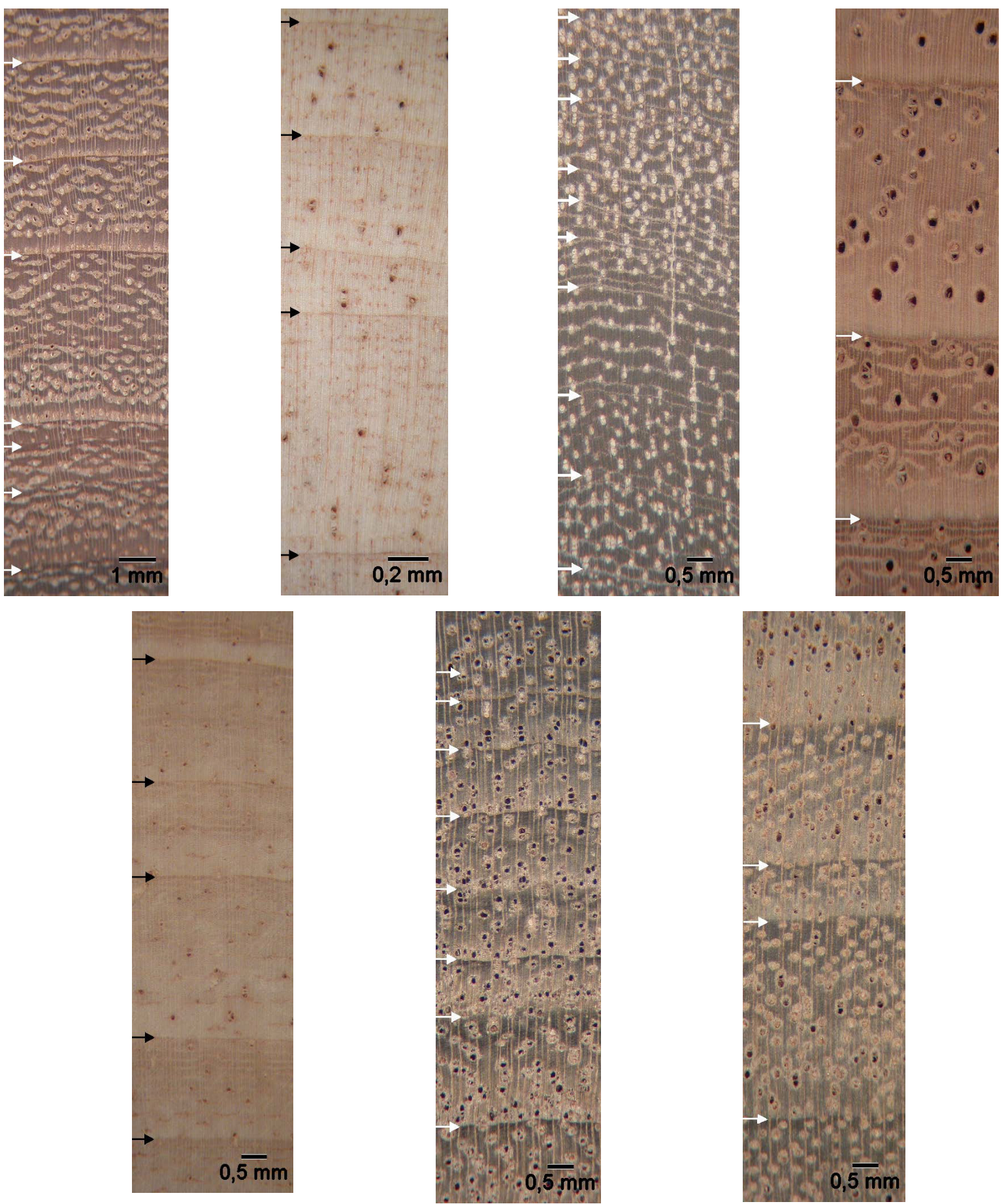

Fig. 11 Wood structure of tree species with distinct and continuous tree-ring boundaries: (from left above to right below) Tabebuia barbata, Bignoninaceae, várzea; Hevea guianensis, Euphorbiaceae, igapó; Piranhea trifoliata, Euphorbiaceae, várzea; Macrolobium acaciifolium; Fabaceae, várzea; Pterocarpus amazonum, Fabaceae, várzea; Endlicheria arunciflora, Lauraceae, igapó; and Nectandra amazonum, Lauraceae, várzea 


\section{How to Measure Growth Dynamics in Tropical Trees}

Despite the importance of basic data for the evaluation of growth and life history of old-growth tropical forests there is a lack of information about wood growth rates and ages of trees. Several traditional methods exist for this purpose, baring different limitations and problems.

Traditional methods of age determination are direct radiocarbon measurements of the oldest parts of a tree, the center of the trunk base (a), calculations from repeated diameter measurements (b) and the prediction of longevity from mortality rates (c).

(a) The advantage of radiocarbon dating is its independence from other metric approaches. Its limitation is the restriction to time periods before 1640. Later the 'Suess effect' hinders an exact determination. Due to the varying ${ }^{14} \mathrm{C}$ content of the atmosphere for the period between 1640 and 1950 up to five possible ages can be related to one radiocarbon age. Nevertheless tree ages from this period are published frequently, either with the oldest calibrated age of a series (Chambers et al. 1998), or with a more conservative but nevertheless questionable approach, the center of several possible calibrated ages (Viera et al. 2005).

(b) Growth trajectories based on short-term measurements give relative reliable results when many individuals of different size classes are regarded and included into the calculation (Clark and Clark 1999). Overestimations of ages are the consequence, if lowest growth rates are combined with highest tree diameters (Lieberman et al. 1985), while the calculation with highest observed growth rates lead to assumed tree ages not older than 500-600 years (Laurance et al. 2004).

c) A pure mathematical approach is the age calculation on the base of mortality rates of a tree species population (Condit et al 1995), which never was validated by other independent techniques.

Tree-ring analysis in tropical trees is not a new approach, but seldom used for applied purposes in the tropics. The annual nature of tropical tree rings is proven since the beginning of the $20^{\text {th }}$ century (Coster 1927). However the huge diversity of tree species, wood structures and site conditions together with the still living paradigm that tropical trees never have annual rings, makes it necessary to prove the wood-growth periodicity of trees at many different sites. Again there are a number of different techniques which are described below:

Phenological observations give a first indication if an external climate factor influences the growth rhythm of a tree; especially in combination with dendrometer 
measurements of short-term trunk increments (Schöngart et al 2002).

Cambial wounding developed by Mariaux (1967) provides exact information on the rhythm of wood formation. The cambium is injured in a small "window" of some square centimeters either mechanically by incision or chemically by injection. The wounds are covered by callus tissue in the consecutive years and remain as artificial and exactly datable scar in the wood.

Another artificial marking is the radiocarbon dating of individual growth zones based on the nuclear weapon effect (Worbes and Junk 1989). The growth periodicity can be proven by counting the number of rings between the radiocarbon dated ring and the youngest ring under the bark. The method is valid for the time between 1950 and today, when the radiocarbon content of the atmosphere doubled until 1963 as the consequence of the bomb explosions and decreased after the test ban treaty.

The dating of tree rings is also possible on the base of fire scars or tree rings with notable properties that differentiate from adjacent rings (pointer years) with exogenous factors such as fire or extreme climatic events (Worbes 1999). Unfortunately, this requires available long time records of such events, which is an obstacle in most tropical regions.

The successful correlation of tree-ring time series with climate records also indicate the existence of annual tree rings. Meanwhile this was carried out for many different tropical habitats reaching from floodplains (Schöngart and Junk 2007), over lowland forests (Brienen and Zuidema 2005) to very dry sites (Fichtler et al. 2004; Schöngart et al. 2006) enabling climate reconstructions for more than 500 years (Therrell et al. 2006). An overview on techniques and additional examples is given in Worbes (2002).

\section{DiscuSSION AND CONCLUSIONS}

Despite the large variability of tree rings from tropical regions, the existence of their annual nature could be proven for many tree species and is generally known since more than 100 years (overview in Worbes 2002). To ensure the successful application of dendrochronological studies a detailed knowledge of wood-anatomical structures and the variability of growth zones is required. In studies on time series analysis it is essential to start with species, known to be suitable for tree-ring analysis or with complete stem discs. Working with discs allows following the course of individual growth zones over the entire cross section and results in a reliable, correctly dated, reference data set to cross-date additional segments 
or cores. The use of concurring sections with distinguishable rings situated on different radii allows the exact counting of the trees age and even ring-width measurements in samples showing frequently wedging rings. After an initial classification of the tree-ring structure from disc samples, additional samples can be taken with an increment corer. In climatological studies, special carefulness should be paid to the inner parts of the stem (juvenile wood) as young trees in the tropics usually are influenced by strong competition and may show a different response to growth limiting factors compared to mature trees.

Notwithstanding all the potential difficulties many species from the várzea and igapó form distinct and continuous annual rings, suitable for tree-ring analysis. Excellent examples for that are species from the genera Tabebuia, Hevea, Piranhea, Macrolobium, Pterocarpus, Endlichera or Nectandra (cf. Table 1 and Fig. 11).

On this basis and under consideration of the above mentioned variations and peculiarities of the anatomical structures, tree-ring analysis can be used for a wide range of applications. Thereby special interest should be paid to gain realistic increment data for the implementation of sustainable management plans, reliable proxy data for tropical climate reconstruction and real tree ages for understanding forest and population dynamics. An example is the reconstruction of the Southern Oscillation Effect (ENSO) with tree-ring data for the $19^{\text {th }}$ century using the tree species Piranhea trifoliata in the várzea (Schöngart et al. 2004). An important discussion of academic interest as well as in the frame of carbon sequestration is the question of the maximum age of tropical tree species. In a review of recent literature on forest dynamics and carbon fluxes, the maximum age reported for the oldest tropical forest trees was found to increase rapidly among successive studies (Worbes and Junk 1999). These studies calculate or model the maximum age of tropical trees and tend to overestimate considerably (Condit et al. 1995), with the focus on the oldest theoretically possible age (Laurance et al. 2004).

In a Central Amazonian forest, however, three individual trees were reported to be between 900 and 1400yr old (Chambers et al. 1998). Those findings are clear outliers to all other findings from tropical forests. They were based on single samples from each tree and single radiocarbon estimations, without any corroborating data or replicated analyses. An analysis with radiocarbon dating confirmed by tree-ring counting in a forest in Costa Rica resulted in 530 years for a large Hymenolobium mesoamericanum with very dense wood (Fichtler et al. 2003), what is an indicator for slow growth and high age. Other tree-ring based studies confirm 400-500 years as maximum age for tall growing timber species (Worbes and Junk 1999; Brienen and Zuidema, 2006). This shows that the age of tropical trees does not 
exceed principally that from temperate zone broad leaf species (Loehle 1988).

All of the above described aspects of wood and tree-ring formation are not limited to Amazonian floodplain forests, but of general nature for tropical trees. The results stimulated tropical tree-ring analysis as a whole in the last 20 years and helped to overcome the old paradigm that tropical trees do not form annual rings.

\section{ACKNOWLEDGMENTS}

E. Fichtler was sponsored by the Scholarship Programme of the German Federal Environmental Foundation (DBU). We thank Dieter Eckstein and Jochen Schöngart for their careful review and valuable comments on this chapter. 


\section{REFERENCES}

Baas P (1990) Ecological trends in the wood anatomy and their biological significance. In Schweingruber FH. (Ed.) 1990. Anatomy of European woods. Birmensdorf, Eidgenössische Forschunngsanstalt WSL. Bern Stuttgart, Wien; Haupt

Brienen RJW, Zuidema PA (2005) Relating tree growth to rainfall in Bolivian rain forests: a test for six species using tree ring analysis. Oecologia 146: 1-12

Brienen RJW, Zuidema PA (2006) Lifetime growth patterns and ages of Bolivian rain forest trees obtained by tree ring analysis Journal of Ecology 94: 481-493

Carlquist S (1988) Comparative wood anatomy. Springer: Berlin, Heidelberg, New York

Chambers JQ, Higuchi N, Schimmel JP (1998) Ancient trees in Amazonia. Nature 391: 135136

Clark DA, Clark DB (1999) Assessing the growth of tropical rain forest trees: Issues for forest modelling and management. Ecological Applications 9: 981-997

Condit R, Hubbell SP, Foster RB (1995) Mortality rates of 205 neotropical tree and shrub species and the impact of a severe drought. Ecol. Monogr. 65: 418-439

Coster C (1927) Zur Anatomie und Physiologie der Zuwachszonen und Jahresringbildung in den Tropen. Annales du Jardin Botanique de Buitenzorg 37: 49-160

Coster C (1928) Zur Anatomie und Physiologie der Zuwachszonen und Jahresringbildung in den Tropen. Annales du Jardin Botanique de Buitenzorg 38: 1-114

Dünisch O, Puls J (2003) Changes in content of reserve materials in an evergreen, a semideciduous, and a deciduous Meliaceae species from the Amazon. Journal of Applied Botany 77: 10-16

Dünisch O, Bauch J, Sack M, Müller M (1999) Growth dynamics in wood formation of plantation-grown Swietenia macrophylla KING and Carapa guianensis AUBL. Mitt. Bundesforschungsanstalt Forst und Holzwirtschaft, Hamburg, 193: 79-96

Fichtler E, Clark DA, Worbes M (2003) Age and long-term growth of trees in an old-growth tropical rain forest, based on analyses of tree rings and ${ }^{14} \mathrm{C}$. Biotropica 35 : 306-317

Fichtler E, Trouet V, Beeckman H, Coppin P, Worbes M (2004) Climatic signals in tree rings of Burkea africana and Pterocarpus angolensis from semiarid forests in Namibia. Trees - Structure and Function 18: 442-451

Fink S (1982) Histochemical investigations on starch-distribution and activity of acidphosphatases in the xylem of some tropical tree species. Holzforschung 36: 295-302 
Gessner F (1968) Zur ökologischen Problematik der Überschwemmungswälder des Amazonas. Internationale Revue der gesamten Hydrobiologie 53: 525-547

Laurance WF, Nascimento HEM, Laurance SG, Condit R, D'Angelo S, Andrade A (2004) Inferred longevity of Amazonian rainforest trees based on a long-term demographic study. Forest Ecology and Management 190: 131-143

Lieberman D, Lieberman M, Hartshorn G, Peralta R (1985) Growth rates and age size relationships of tropical wet forest trees in Costa Rica. Journal of Tropical Ecology 1: 97-109

Loehle C (1988) Tree life history strategies: The role of defenses. Can. J. For. Res. 18: 209222

Mariaux A (1967) Les cernes dans les bois tropicaux africains, nature e périodicité. Bois et Fôrets des Tropiques 113: 3-14; 114: 23-37

Parolin P, Wittmann F, Schöngart J (2010) Tree phenology in Amazonian floodplain forests. In: Junk WJ, Piedade MTF, Wittmann F, Schöngart J, Parolin P (eds) Central Amazonian floodplain forests: ecophysiology, biodiversity, and sustainable management. Springer, Berlin/Heidelberg/New York

Schöngart J (2010) Growth-Oriented Logging (GOL): the Use of Species-Specific Growth Information for Forest Management in Central Amazonian Floodplains. In: Junk WJ, Piedade MTF, Wittmann F, Schöngart J, Parolin P (eds) Central Amazonian floodplain forests: ecophysiology, biodiversity, and sustainable management. Springer, Berlin/Heidelberg/New York

Schöngart J, Piedade MFT, Ludwigshausen S, Horna V, Worbes M (2002) Phenology and stem-growth periodicity of tree species in Amazonian floodplain forests. Journal of Tropical Ecology 18: 581-597

Schöngart J, Junk WJ, Piedade MTF, Ayres JM, Huttermann A, Worbes M (2004) Teleconnection between tree growth in the Amazonian floodplains and the El NinoSouthern Oscillation effect. Global Change Biology 10: 683-692

Schöngart J, Piedade MTF, Wittmann F, Junk WJ, Worbes M (2005) Wood growth patterns of Macrolobium acaciifolium (Benth.) Benth. (Fabaceae) in Amazonian black-water and white-water floodplain forests. Oecologia 145: 654-661

Schöngart J, Orthmann B, Henneberg KJ, Porembski S, Worbes M (2006) Climate-growth relationships of tropical tree species in West Africa and their potential for climate reconstruction. Global Change Biol 12: 1139-1150

Schöngart J, Wittmann F, Worbes M (2010) Biomass and NPPof Central Amazonian 
floodplain forests. In: Junk WJ, Piedade MTF, Wittmann F, Schöngart J, Parolin P (eds) Central Amazonian floodplain forests: ecophysiology, biodiversity, and sustainable management. Springer, Berlin/Heidelberg/New York

Schweingruber FH (2001) Dendroökologische Holzanatomie. Anatomische Grundlagen der Dendrochronologie. Birmensdorf, Eidgenössische Forschunngsanstalt WSL. Bern Stuttgart, Wien; Haupt

Therrell MD, Stahle DW, Diaz JV, Oviedo EH, Cleaveland MK (2006) Tree-ring reconstructed maize yield in central Mexico: 1474-2001. Climatic Change 74: 493-504

Vieira S, Trumbore S, Camargo PB, Selhorst D, Chambers JQ, Higuchi N, Martinelli LA (2005) Slow growth rates of Amazonian trees: Consequences for carbon cycling. Proceedings of the National Academy of Sciences of the United States of America 102: $18502-18507$

Worbes M (1984) Periodische Zuwachszonen an Bäumen zentralamazonischer Überschwemmungswälder. Naturwissenschaften 71: 157-158

Worbes M (1985) Structural and other adaptations to longterm flooding by trees in Central Amazonia. Amazoniana IX (3), 459-484

Worbes M (1995) How to measure growth dynamics in tropical trees. - A review -. IAWA Journal 16: 337-351

Worbes M (1997) The forest ecosystem of the floodplains. In: Junk, W. J. (Hrsg.). The Central Amazon Floodplains. Ecology of a Pulsing System. Springer Verlag, BerlinHeidelberg-New York, 223-266

Worbes M (1999) Annual growth rings, rainfall-dependent growth and long-term growth patterns of tropical trees from the Caparo Forest Reserve in Venezuela. Journal of Ecology 87: 391-403

Worbes M (2002) One hundred years of tree ring research in the tropics. - A brief history and an outlook to future challenges. Dendrochronologia 20/1-2: 217-231

Worbes M, Junk WJ (1989) Dating tropical trees by means of the ${ }^{14} \mathrm{C}$ from bomb tests. Ecology 70 (2): 503-507

Worbes M, Junk WJ (1999) How old are tropical trees? The persistence of a myth. IAWA Journal 20 (3): 255-260

Worbes M, Klinge H, Revilla JD, Martius C (1992) On the dynamics, floristic subdivision and geographical-distribution of varzeá forests in central Amazonia. Journal of Vegetation Science 3: 553-564 


\section{Climatic Signals IN TREe RINGS OF BURKEA AFRICANA AND PTEROCARPUS ANGOLENSIS FROM SEMIARID FORESTS IN NAMIBIA}

Esther FichtLer, Valerie Trouet, Hans Beeckman, Pol Coppin \& Martin Worbes

PUBLISHED IN:

Trees - StRucture and Function 2004, Volume 18, Number 4, Pages 442-451

(DOI: 10.1007/s00468-004-0324-0)

\section{AbSTRACT}

Tree-ring studies contribute worldwide to the understanding of climate and its relation to tree growth. Long tree-ring chronologies serve as climate proxies for the reconstruction of past, pre-instrumental climate and its recent change. In tropical regions, the availability of exactly-dated tree-ring chronologies is limited. The dendroclimatic potential of two dominant species from dry forests in Northern Namibia was examined in the study presented in this paper. Both species (Burkea africana Hook and Pterocarpus angolensis DC) were sampled at two sites ( ca. $900 \mathrm{~km}$ apart) and the response to several climatic variables, including ENSO indices, is studied.

All specimens showed distinct growth rings and crossdating between radii was successful for all trees. Species-specific mean curves were built for both sites. The mean curves of different species of the same site synchronised significantly, allowing the construction of a site-specific chronology. Synchronisation between sites was not possible, but spectral analysis of the chronologies implied that both show a similar long-term (6.7 year) oscillation patterns.

Burkea africana is more sensitive to rainfall variations than Pterocarpus angolensis at both sites. Growth response to rainfall was positive, but a time-lag in the reaction occurred between the sites, corresponding to the time-lag of the beginning of the rainy season. Air 
temperature showed a negative correlation with stem increment at both sites. The response at the westernmost site to two ENSO indices indicates a tree growth decrease during El Niño years, which are generally dry in Southern Africa.

\section{INTRODUCTION}

To understand natural climate variability and the magnitude of possible human impact on it, high resolution, long-term climate data are needed (Bradley et al. 1996). The availability of such data becomes more urgent in critical regions, where the environment is closely linked with its climate (Yadav and Singh 2002). Because the major part of southern Africa suffers from poor infrastructure and low socio-economic development, the consequences of extreme weather or climate anomalies are often devastating to both people and property (Fauchereau et al. 2003). High vulnerability to weather and climate hazards, associated with the growing population make southern Africa one of the regions where potential changes in the hydrological cycle due to global warming could lead to extreme negative impacts on societies (Shulze et al. 2001).

Climatic time-series, as provided by instrument-acquired records, are very limited in Africa, in time as well as in space (Anyamba and Eastman 1996). Proxy data offer a potential solution to this problem. Tree-ring data in particular often have a fixed annual resolution and can produce absolute time-series (Cook 1992). If trees show annual rings, dendrochronology is doubtless the safest and most reproducible way of age dating (Worbes 2002). Long-term ring chronologies are a potentially powerful tool for analyzing demographic trends and ecological factors influencing growth in tropical trees (Vetter and Botosso 1989). Previous tree-ring studies have shown the dendroclimatic potential of several tree species in southern Africa (February 2000; Gourlay 1995; Stahle et al. 1996, 1999; Trouet et al. 2001, 2004). Basic knowledge of the relationship between environmental variables and tree growth is crucial for the prediction of future growth responses to climatic variation (Pumijumnong 1999) and to long-term phenomena as ENSO (Cook 1992).

Recent climatic change may bring about rapid environmental changes that may have extreme impacts on tree growth (Jalilvand et al. 2001), as tropical tree growth is sensitive to the timing and variation in local climatic regimes (Enquist and Leffler 2001). Global warming could also partly be related to the enhanced influence of El Niño Southern Oscillation 
(ENSO) on Southern African rainfall (Fauchereau et al. 2003). The reconstruction of the regional influence of ENSO on climate, can only be derived from information acquired in the center of the relevant region and therefore proxy data need to be acquired locally (D'Arrigo and Jacoby 1992).

This study examines the potential of tree rings of two indigenous species in Namibia for dendrochronological studies and the connection between tree growth and climate for these species. Up to now no chronologies are available for Burkea africana Hook or Pterocarpus angolensis DC from Namibian stands, although for the latter a short chronology from Zimbabwe exists (Stahle et al. 1999). Special emphasis is placed on the connection between tree growth and the ENSO phenomenon.

\section{Material ANd MethodS}

STUDY SITES At two sites in northern Namibia, Ondangwa $\left(17^{\prime} 56^{\circ} \mathrm{S}, 15^{\prime} 59^{\circ} \mathrm{E}\right)$ and Katima Mulilo $\left(17^{\prime} 30^{\circ} \mathrm{S}, 2^{\prime} 17^{\circ} \mathrm{E}\right), 32$ individual trees of two species (Burkea africana Hook, Caesalpiniaceae; Pterocarpus angolensis DC, Papilionaceae, both Leguminosae family) were sampled during the dry season of 1998 (Katima Mulilo) and 2000 (Ondangwa). Total annual rainfall is lower in Ondangwa (454 mm) as compared to Katima Mulilo (672 $\mathrm{mm})$. The climate of both sites is characterised by an annual dry season of 5 to 7 months with less than $50 \mathrm{~mm}$ precipitation (Fig. 1), which lasts in general from May to October.

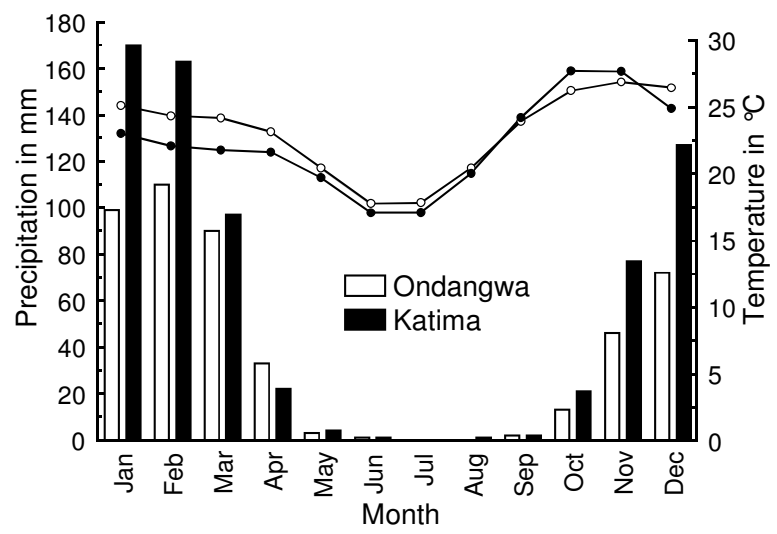

Fig. 1 Annual distribution of rainfall (bars) and temperature (lines) at Ondangwa (white) and Katima Mulilo (black) 
TREE SPECIES Both tree species are common in southern African woodlands. Burkea africana (Red Syringa) is a medium sized tree usually 8 to $10 \mathrm{~m}$ tall, with a maximum height of 20 m (Coates Palgrave 1997; Storrs 1995). It occurs in various types of woodlands over a wide range of altitudes and habitats, but is most characteristic for hot, low-lying areas (Coates Palgrave 1997). Leaf fall takes place from May to September and new leaves flush from August to December. Flowers appear from August to November whereas fruits ripen from February to October but can remain on the tree for a very long time (Coates Palgrave 1997; Storrs 1995). The wood is hard, heavy $\left(865 \mathrm{~kg} / \mathrm{m}^{3}\right.$ at $12 \%$ moisture content, Goldsmith and Carter 1981) and tough. Because of its small tree stature the wood is limited in use.

Pterocarpus angolensis (African Blood wood) is a medium sized to large tree up to 16 m high, but reaching 28 m under ideal conditions (Coates Palgrave 1997; Storrs 1995). It occurs in woodland and wooded grasslands. Leaves fall from May to June and new ones emerge from September to October. Flowering takes place in the months August to December while fruiting occurs from January to June (Coates Palgrave 1997; Storrs 1995). Pterocarpus angolensis is very resistant to fire. It is one of the best-known, most generally used and most valuable timber in southern tropical Africa (Coates Palgrave 1997) with a density of 640 $\mathrm{kg} / \mathrm{m}^{3}$ at $12 \%$ moisture content (Goldsmith and Carter 1981).

Tree-RING ANALYSIS All samples consisted of full stem discs. The discs were dried in open air and polished progressively with sanding paper bands up to grit 600 . Then the samples were cleaned from dust with compressed air.

Tree-ring structure was analysed under a stereo-microscope with low magnification. Ring boundaries were marked starting from the wane edge to the centre, with special attention paid to the determination and registration of wedging rings.

Ring widths were measured to the nearest $0.01 \mathrm{~mm}$ using LINTAB equipment (Rinn and Jäkel 1997). To avoid any inaccuracy the discs were readjusted during the procedure to measure perpendicularly to the rings.

Crossdating AND Indexation Growth curves are compared visually and statistically to bring ring-width series in a synchronous position (Pilcher 1990; Worbes 1995). Successful cross-dating indicates the influence of an external growth factor on tree growth in 
a region (Eckstein et al. 1981). To gain reliable results the overlap of crossdated time series should reach a minimum of 40 years (Pilcher 1990). The Student's T-Value expresses the degree of affinity of two time series (Baillie and Pilcher 1973):

Student's $T=r \cdot \frac{\sqrt{n-2}}{\sqrt{1-r^{2}}}$

where $n$ is the number of values and $r$ is the correlation coefficient.

In addition to this the "Gleichläufigkeitskoeffizient" (GLK) is used in dendrochronology to investigate the success of crossdating. The Gleichläufigkeit is a measure of the year-to-year agreement between the interval trends of two chronologies based upon the sign of agreement, expressed by the following equations (Schweingruber 1988):

$$
G_{(x, y)}=\frac{1}{n-1} \sum_{i=1}^{n-1}\left[G_{i x}+G_{i y}\right]
$$

where $G$, Gleichläufigkeit; $n$, number of values; and $x, y$, series.

The indexation and calculation of the GLK as well as the Student's T-Value were performed with TSAP (Time Series Analysis and Presentation) software (Rinn and Jäkel 1997). In addition mean sensitivity values were calculated for all chronologies to provide a measure of between-ring variability (Schweingruber 1988):

$\bar{S}=\frac{\sum_{i=1}^{n-1}\left[S_{i}+1\right]}{n-1}$ with $S_{i}=\frac{\left(x_{i}-x_{i-1}\right) \cdot 2}{\left(x_{i}+x_{i-1}\right)}$

where $S$ is the sensitivity and $\mathrm{n}$ is the number of values.

In order to obtain a correlation coefficient that can be interpreted correctly, a transformation of the time series into indexed curves is necessary (Cook and Briffa 1990). Long-term growth trends are thus removed from the individual curves by division of a onesided running mean of 5 years (Baillie and Pilcher 1973; Schweingruber 1988).

In the present study 3 to 4 radii of a tree were visually and statistically crossdated to produce a mean curve for every individual tree. Successfully crossdated ring-width series of different individuals were averaged to build species- and site-specific mean chronologies. In case of successful correlation of the specific chronologies, master chronologies for species and/or stands were obtained in the same way. Correlation analysis with climatic data sets was performed using Pearson's correlation calculation with a 5\% significance level. 
Climate data The climatic data set used for the correlation analysis, contained precipitation, relative humidity and temperature data. Nicholson (2001) defined regions of the African continent, which have been shown to be climatically homogenous with respect to intra- annual variability of rainfall. Mean monthly precipitation data for two corresponding regions were calculated in order to investigate a) long time series and b) the impact of large scale precipitation events. Data from region 61 (including Ondangwa), were available for 1901 up to 2000 (Nicholson, pers. comm.), and data from region 57 (Katima Mulilo) for 1901 up to 1984 (National Center for Atmospheric Research, http://ncardata.ucar.edu/datasets).

Mean monthly relative humidity and temperature data for both sites were derived from the IPSL ClimServ data set (Centre National de la Recherche Scientifique, Laboratoire de Météorologie Dynamique, http://climserv.lmd.polytechnique.fr/las/main.pl) and were available for a time period covering 1948 to 2000.

For the correlation analysis, precipitation data for single months as well as the sum of all months [corresponding to the "growth year" August (n-1) - July $(n)$ ] were used. Further precipitation variables such as the sum of precipitation from August to December (SAD) and January to June (SJJ) were calculated. In addition to this the sum of rainfall in the transition months between dry and rainy season [September to October (SSO)] and between rainy and dry season [April to May (SAM)] were built (cf. Worbes 1999). Depending on the results of the correlation between single months and chronologies, the variables sum of precipitation in October and November (SON) and January and February (SJF) were added to the data set.

In the same way mean monthly and mean annual relative humidity and temperature data were used in the correlation analysis. Additional time series of mean values of August to December (MAD), January to June (MJJ), September to October (MSO), April to May (MAM), November to May (MNM) and finally June to August (MJUNAUG) were constructed.

In addition to correlation with climate data, response of growth ring widths to the El Niño Southern Oscillation (ENSO) signal, as defined by the Southern Oscillation Index (SOI; Ropelewski and Jones 1987) and the Sea Surface Temperature Index for the Niño 3.4 region ( $5^{\circ} \mathrm{N}-5^{\circ} \mathrm{S} ; 120^{\circ}-170^{\circ} \mathrm{W}$; Niño3.4; Trenberth and Stepaniak 2001), was investigated. Therefore monthly deviation and mean annual deviation of these indices were used. In the same way as with temperature and relative humidity mean values of the monthly data were created as the mean from October to August (MOA), May to December (MMD), MAD and MJJ. The time series of these indices were obtained from the NOAA Climate Prediction Center (http://www.cpc.ncep.noaa.gov/data/indices/index.html). Additionally, correlation was 
calculated with time-series of sea surface temperature anomalies (SSTa) from the southern Atlantic Ocean and from the southwestern Indian Ocean. Time-series of these indices were obtained from the NOAA Climate Prediction Center (http://www.cpc.ncep.noaa.gov /data/indices/index.html).

STATISTICAL ANALYSIS Statistical analysis was performed using TSAP and Statistica software. In addition to crossdating and correlation analysis, spectral analysis was executed, which can be used to describe cycles in time series (Jenkins and Watts 1968). The spectra of the chronologies of both stands were analyzed to examine the distribution (over frequency) of the strength of their periodic signal, using Autosignal software (Systat Software Inc.). The significance of the signal's peaks was tested based on Monte Carlo permutation tests (Barnard 1963). Time-series were also filtered using eigendecomposition (Elsner and Tsonis 1996) in order to reveal significant peaks. Furthermore a cross-spectral analysis was performed between the chronologies.

\section{RESULTS}

\section{TREE RING ANALYSIS}

Tree ring structure Both species show distinct growth rings (Fig. 2 and 3). The sites are affected by an annual drought and both species are deciduous, shedding their leaves during the dry period. As cambial activity in tropical trees is generally induced by flushing and terminates some time before leaf shedding (Borchert 1999), the growth patterns found can be considered as consisting of annual rings.

The wood structure of $B$. africana is characterized by a marginal parenchyma band at the limit of a ring often combined with a tissue band containing very few pores (Fig. 2a). In some rings the wood rays become broader on the ring boundary (Fig. 2b). In B. africana wedging rings occur but can be determined by analysing various radii (Trouet et al. 2001).

The tree-ring structure of $P$. angolensis (Fig. 3 a,b) is characterized by a weak ring porous vessel distribution where many larger, mainly solitary, vessels aggregate at the beginning of the ring (Fig. 3a). Apart from that, the rings are delimited by a thin marginal 
parenchyma band and a slight difference in fibre cell wall thickness, between earlywood and latewood (Fig. 3b). P. angolensis shows wedging rings only scarcely, and these can also be determined following the same procedure as in B. africana.

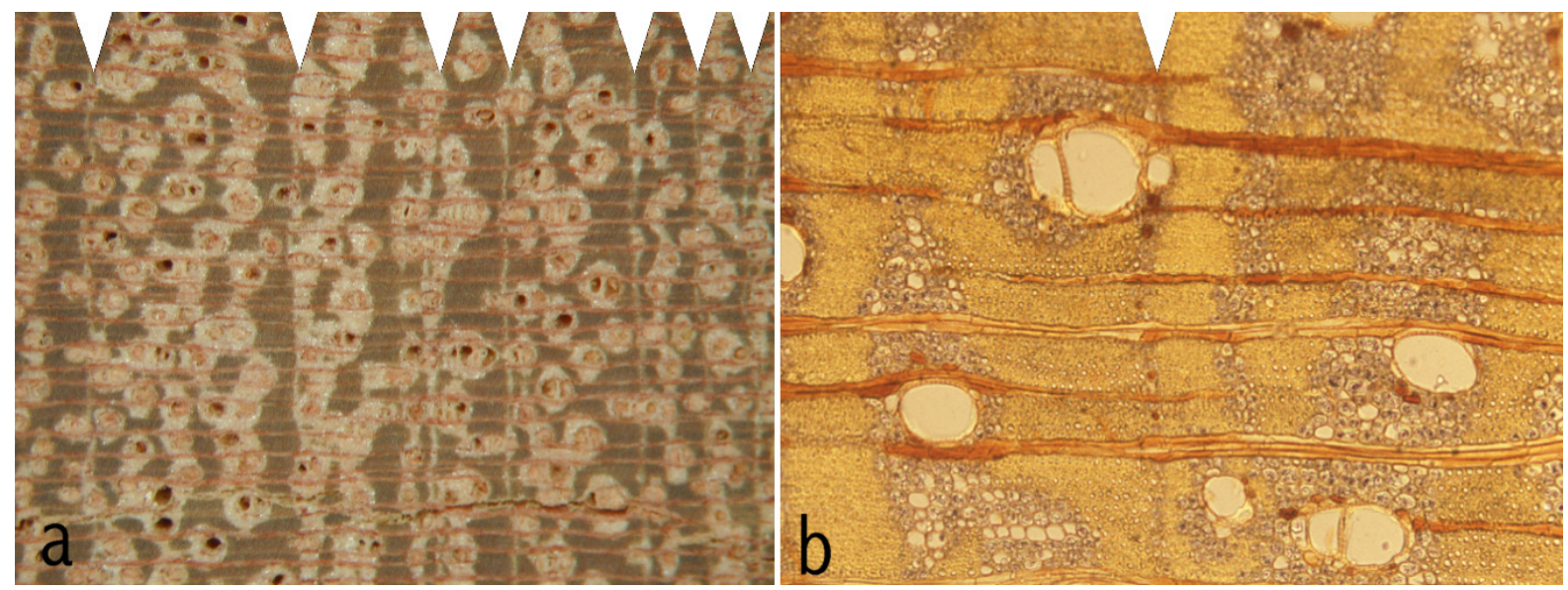

Fig.2 Burkea africana macroscopical (a x16) and microscopical (b x25)); white triangles indicate ring boundaries

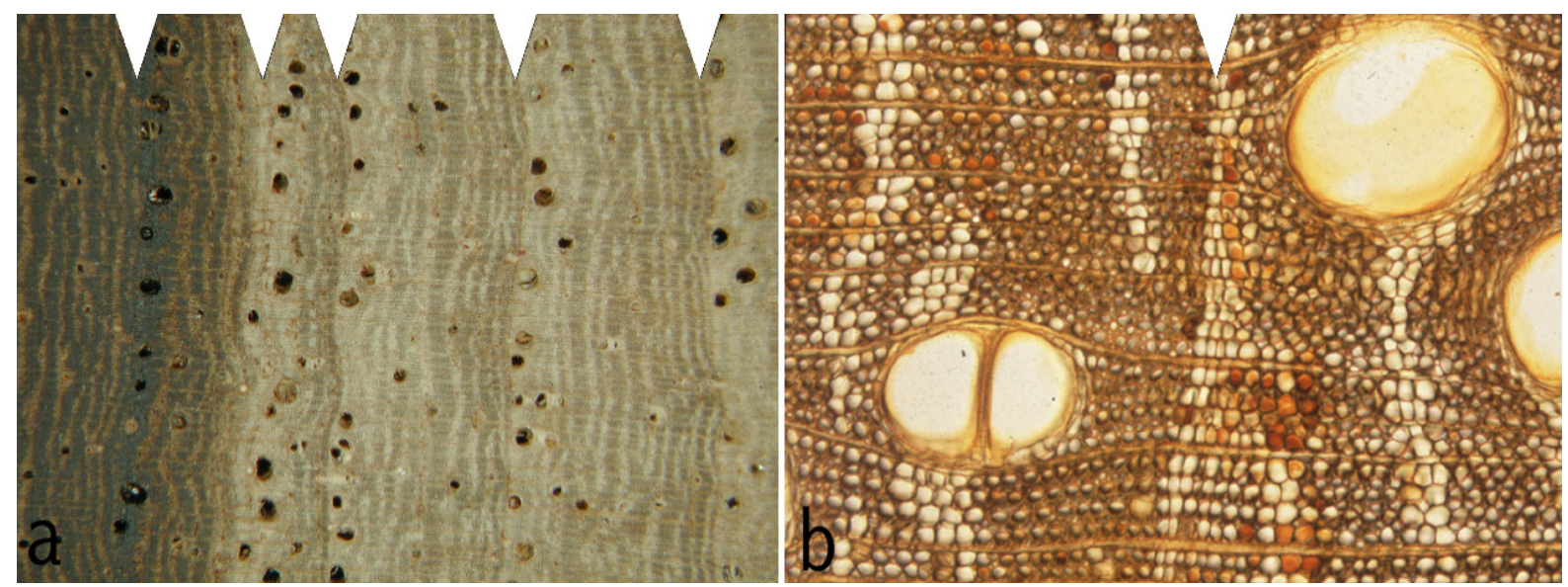

Fig. 3 Pterocarpus angolensis macroscopical (a x10) and microscopical (b x25)); white triangles indicate ring boundaries 
Crossdating Crossdating between radii of the same disc was successful for all trees for both species at both sites. According to Worbes (2002) tree rings of the juvenile wood can not be used, as very young trees (4 to 5 years) respond differently physiologically to climatic factors compared to mature trees.

Crossdating of B. africana trees at Ondangwa was successful for 12 out of 15 trees (Table 1), varying in length between 25 and 187 years. A chronology was constructed for this site with a length of 110 years (based on four contributing trees) and a mean sensitivity value of 0.27. All five sampled trees of B. africana at Katima Mulilo, contributed to the chronology, which had a length of 65 years (based on four contributing trees) and a mean sensitivity value of 0.29 . The master chronology of $P$. angolensis at Ondangwa consisted of 5 out of 8 sampled trees. It had a length of 79 years (based on four contributing trees) and a mean sensitivity value of 0.31 . Finally the chronology of P. angolensis at Katima Mulilo consisted of all four studied individuals with an age between 15 and 152 and had a length of 60 years (based on four contributing trees) with a mean sensitivity value of 0.41 . The species-specific chronologies built for both sites are shown in Fig. 4.

Cross dating among different species from the same sites was possible with significant T-values (with $\mathrm{p}<0.05$ ) and GLK values (Table 2), but the chronologies of the same species at the two different sites did not correlate strongly. The master chronology for Ondangwa thus consists of 17 series, while the master chronology for Katima Mulilo consists of 9.

Table 1 Sampling and chronology characteristics for Ondangwa and Katima Mulilo

\begin{tabular}{cccccc}
\hline Study site & Species & $\begin{array}{c}\text { No. of samples } \\
\text { available }\end{array}$ & $\begin{array}{c}\text { No. trees / } \\
\text { chrono }\end{array}$ & $\begin{array}{c}\text { Age chronology } \\
\text { (years } \geq 4 \text { trees) }\end{array}$ & $\begin{array}{c}\text { Mean } \\
\text { Sensitivity }\end{array}$ \\
\hline Ondangwa & B. africana & 15 & 12 & 110 & 0.27 \\
& P. angolensis & 8 & 5 & 79 & 0.31 \\
\hline Katima Mulilo & B. africana & 5 & 5 & 65 & 0.29 \\
& P. angolensis & 4 & 4 & 60 & 0.41 \\
\hline
\end{tabular}




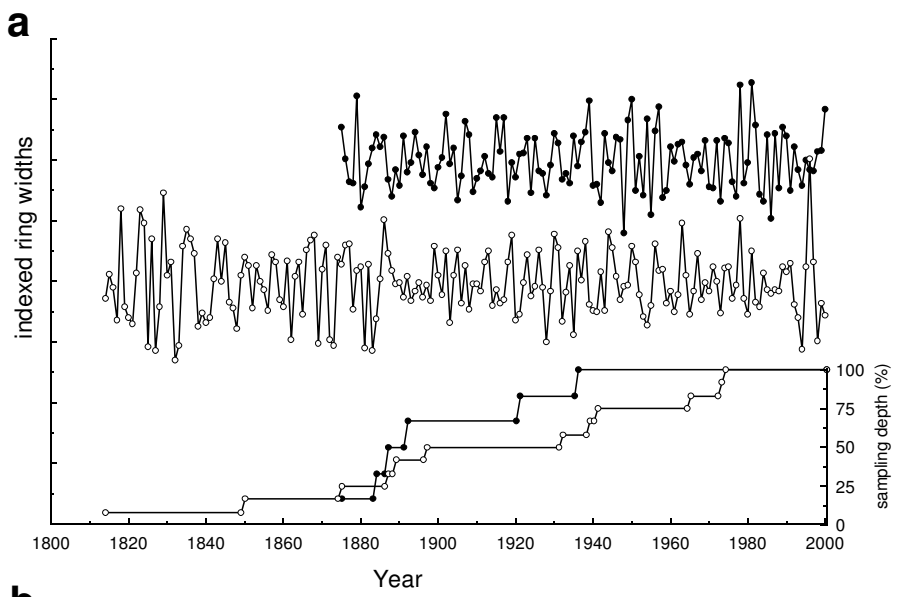

Fig. 4 Chronologies and sampling depth for $B$. africana and $P$. angolensis at Ondangwa (a) and Katima Mulilo (b). Sampling depth $100 \%$ in Ondangwa for B. africana (12 trees), and for P. angolensis (5 trees); in Katima Mulilo for $B$. africana (5 trees), for $P$. angolensis (4 trees)

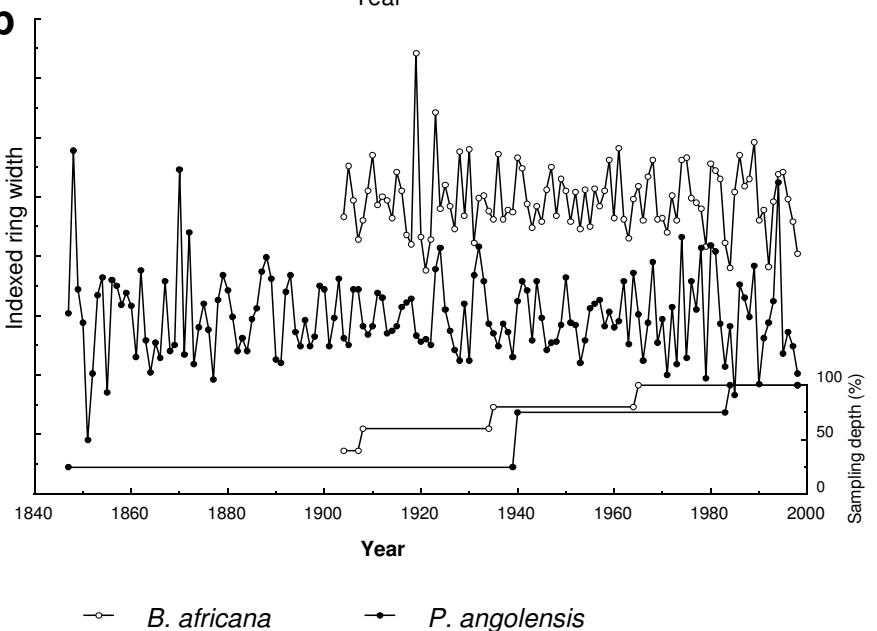

Table 2 Gleichläufigkeitskoeffizient (GLK), $T$-value, $r$-value and overlap period $(O V L)$ for the crossdating of B. africana and $P$. angolensis at the two sites

\begin{tabular}{llcccc}
\hline \multicolumn{1}{c}{ Study site } & Species & GLK & $T$-value & $\begin{array}{c}r \text {-value } \\
(\mathrm{p}<0.05)\end{array}$ & OVL \\
\hline Ondangwa & Burkea vs Pterocarpus & 63 & 2.8 & 0.264 & 81 \\
\hline Katima Mulilo & Burkea vs Pterocarpus & 68 & 3.9 & 0.472 & 59 \\
\hline
\end{tabular}

Spectral analysis The spectral analysis reveals for both chronologies significant (>95\%) peaks in the frequency domain of 0.145 to 0.155 (Fig. 5), corresponding to periods of 6.4 to 6.9 years. Cross-spectral analysis shows a coherency of 0.86 between the chronologies at a frequency of 0.155 . The Ondangwa chronology shows a second peak at a frequency of 0.277 (3.6 years), which is significant ( $>99 \%$ ) when the first four signal components of the time series are filtered. 


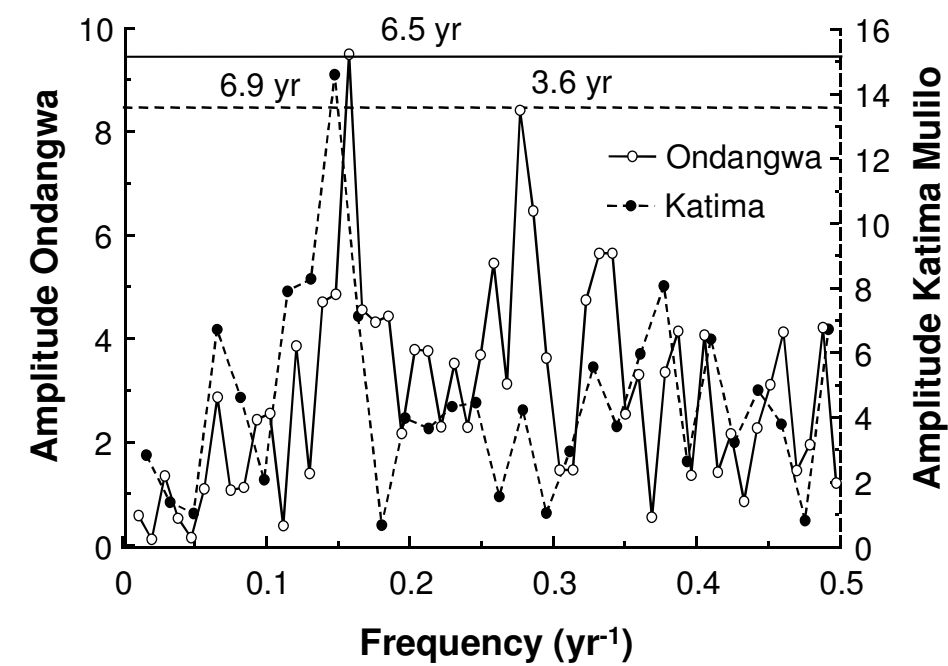

Fig. 5 Results of the spectral analysis of the master chronologies from Ondangwa (1890-2000) and Katima Mulilo (1938-1998). 95\% significance levels are shown as solid lines (Ondangwa) and dashed lines (Katima Mulilo)

Response to Climate A correlation analysis was conducted using the species-specific chronologies and the master chronologies for both sites. Response to all climatic variables was tested separately.

Response to Precipitation B. africana shows for both sites higher correlations to rainfall variables than $P$. angolensis, which is only highly correlated to rainfall in April and to the summed rainfall of April and May in Katima Mulilo (Fig. 6). In Ondangwa, B. africana responds strongly to rainfall in January and February. In addition, the chronology correlates to the total rainfall over the vegetation period. In Katima Mulilo, strong correlations between the B. africana chronology and the rainfall data are found for the months of August, September and November, as well as for the sum of the months October and November.

Response to Temperature and Relative Humidity In Ondangwa, strong responses to both relative humidity and temperature were found for the $B$. africana chronology, but not for $P$. angolensis. In contrast to, at Katima Mulilo, only $P$. angolensis was strongly influenced by these climate variables. For both sites, no additional significant results were obtained by using the master chronologies. Correlation for both sites is shown in Fig. 7. In general, influence of relative humidity was more explicit in Ondangwa as compared to Katima Mulilo. Tree growth of B. africana in Ondangwa was negatively correlated to relative humidity of the beginning of the growing season (August to December), but correlation tended to be positive towards the second half (January to June). No similar trend was found for Katima Mulilo. Response was 
negative for the months October, November and the mean of September and October in Ondangwa and for the month October only in Katima Mulilo.

Correlation with temperature data was stronger for P. angolensis in Katima Mulilo than for B. africana in Ondangwa. For both sites, correlation was negative in general and tended to become stronger towards the end of the growing season. Negative correlation was found with temperatures of the month of April for Ondangwa and the months of May up to July for Katima Mulilo. Correlation was also strong for the mean of the corresponding months (April-May). In addition to this, the mean temperature of the first half of the growing season (August to December) as well as the second half (January to July), had a negative influence at both sites. At Katima Mulilo, tree growth of $P$. angolensis was negatively correlated to the mean annual temperature.

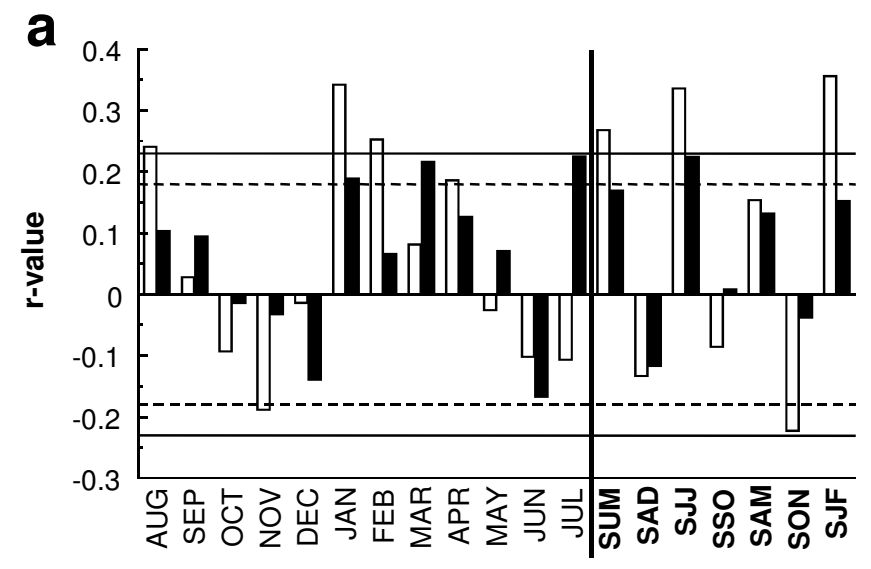

b

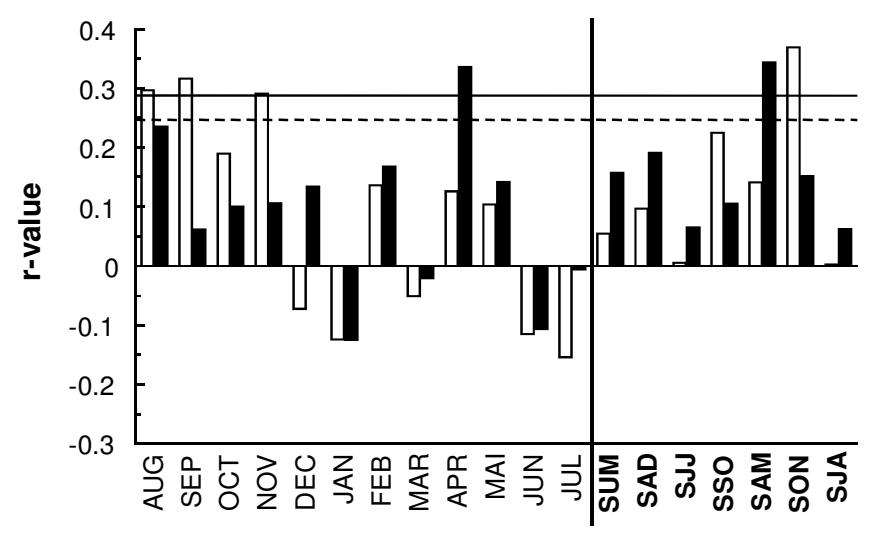

Fig. 6 Response of B. africana and $P$. angolensis chronologies from Ondangwa (a) and Katima Mulilo (b) to rainfall. Rainfall variables used are monthly rainfall data $(A U G$ to $J U L)$ and various sums over longer periods (cf. Material and methods). Significance levels are shown as solid lines $(P=0.05)$ and dashed lines $(P=0.1)$ 

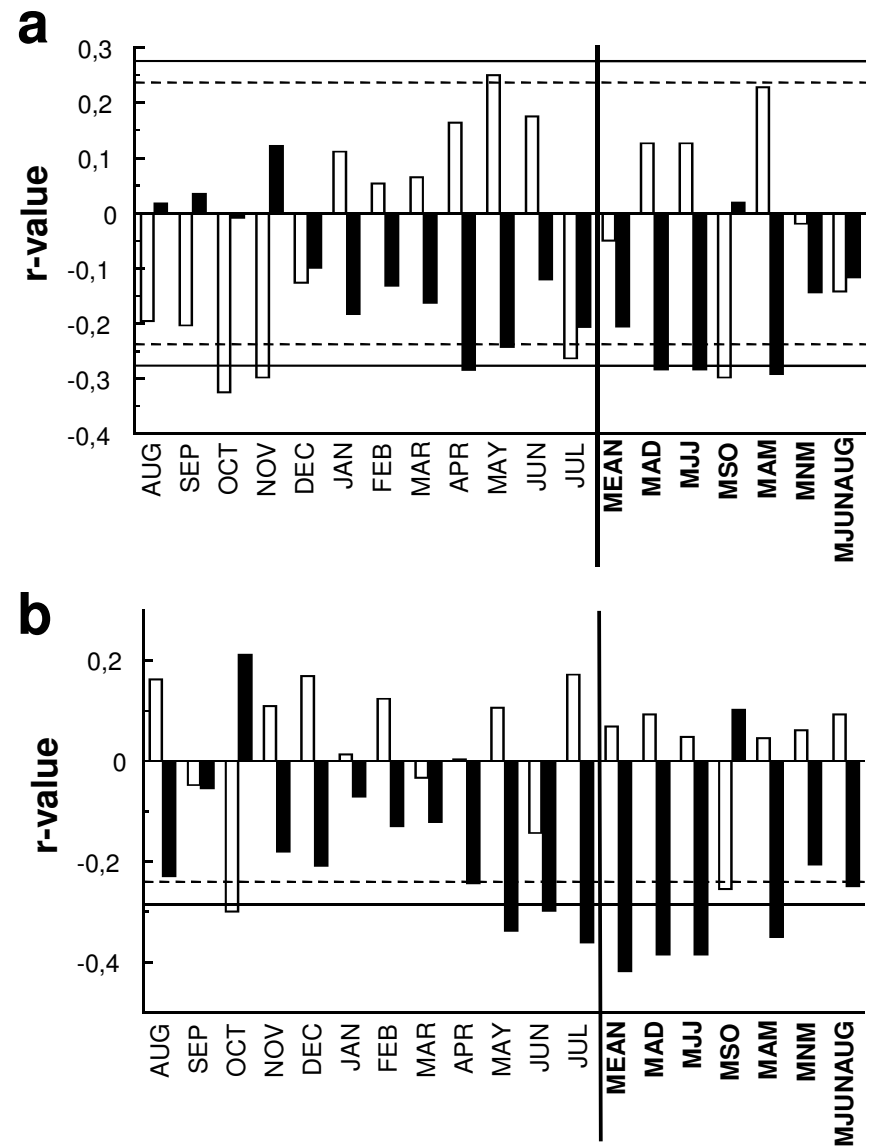

$\mathrm{RH}$
Fig. 7 Response to relative humidity $(R H)$ and temperature (temp) of the $B$. africana chronology in Ondangwa (a) and the $P$. angolensis chronology in Katima Mulilo (b). Climatic variables used are monthly data ( $A U G$ to $J U L)$ and various means over longer periods (cf. Materials and methods). Significance levels are shown as solid lines $(P=0.05)$ and dashed lines $(P=0.1)$

Response to ENSO The individual chronologies of $B$. africana and $P$. angolensis showed a less strong correlation with ENSO than the master chronology at Ondangwa (Fig. 8). Correlation analysis of all chronologies at the Katima Mulilo site yielded no significant results.

The response of the Ondangwa chronology to both indices is overall positive to SOI and negative to Niño 3.4. Response to Niño 3.4 is negative for all individual months from May previous to the growth year up to March of the growth year. Response to Niño 3.4 of the end of the growing season (April-July) is weak. This trend is not visible in the response to SOI, where strong results are found throughout the growth year (August, October, January, April and May).

No response was found to the Indian Ocean SSTa time-series, but the Ondangwa chronology responded strongly to southern Atlantic Ocean SSTa of the months of May $(r=0.43, p<0.05)$ and June $(r=0.37, p<0.05)$ previous to the growth year. 


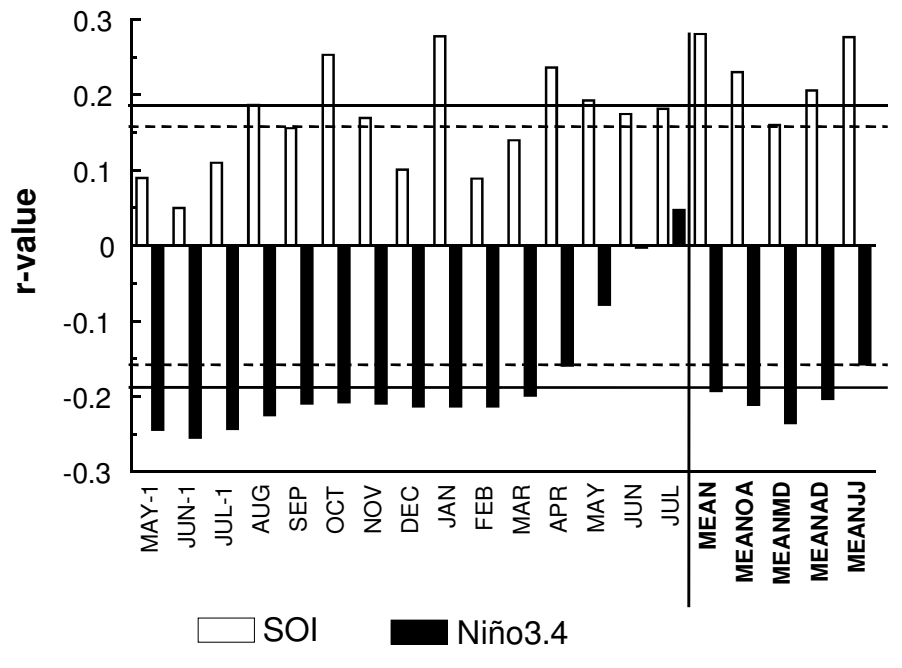

Fig. 8 Response to two ENSOindices (SOI and Nino3.4) of the master chronology at Ondangwa (1890-2000). ENSO-indices used run from May of the previous year $(M A Y-1)$ to July of the growth year $(J U L)$. In addition to this, mean indices over several months were used. Significance levels are shown as solid lines $(P=0.05)$ and dashed lines $(P=0.1)$

\section{DISCUSSION}

The tree species investigated in the present study show distinct ring structures. A pronounced seasonality of rainfall appears at both sites, which provides an absolute annual rhythm in radial growth. This is obvious by the fact that the tree species are deciduous, shedding their leaves during the dry season, which makes the trees produce visible growth rings. As we investigated complete stem discs, no difficulties were caused by missing rings. Crossdating of the ring widths over the entire life span of the individual trees was successful for both species at both stands. Successful crossdating between individuals within the same stands expresses an external oscillation factor influencing tree growth (Worbes 1995). Thus, the growth of the studied tree species is periodical, tied to the annual calendar by seasonality of climate and synchronized among many trees in the same region by inter-annual variation in the shared regional climate (Stahle et al.1999). It can be concluded that tree rings in $B$. africana and $P$. angolensis are of annual nature.

Both species show a rather strong correlation between ring width and climate, suggesting that tree growth of $B$. africana and $P$. angolensis is sensitive to climate. The growth of $B$. africana seems to be more sensitive to precipitation at both sites, while $P$. angolensis shows stronger correlation with temperature and relative humidity at Katima Mulilo. The different sensitivity to rainfall could be a hint to different water-use strategies: for 
B. africana the rooting depth lies between 15 and $60 \mathrm{~cm}$ (Rutherford 1983) while for $P$. angolensis the range of the rooting depths lies between 30 and $200 \mathrm{~cm}$ (Vermeulen 1990). This indicates better access to groundwater in P. angolensis compared to B. africana, while the latter is more affected by different rainfall conditions.

In Katima Mulilo the strongest correlation between rainfall and tree growth is found in the period from September to November, in Ondangwa from January to April (cf. Fig. 6). In Katima Mulilo the rainy season starts up to a month earlier and is thereby more intensive with mean monthly precipitation above $50 \mathrm{~mm}$ already in November and a total of 3 months above $100 \mathrm{~mm}$ monthly rainfall (cf. Fig. 1). In Ondangwa the first month above $50 \mathrm{~mm}$ rainfall per month is December and amounts above $100 \mathrm{~mm}$ are only reached in one month i.e. February. The crucial time of the vegetation period and thus the time of tree growth corresponds to the months with high precipitation rates (Worbes 1999). In Katima Mulilo these are the first months of the vegetation period compared to Ondangwa, where the highest rainfall occurs in the second half of the vegetation period. Interannual variation during and around the crucial months concerning rainfall could cause variation in growth and could thereby explain the time-lag of the strongest correlation of rainfall and tree growth at the two stands. As all significant responses to rainfall are positive, higher precipitation rates seem to have a positive influence on tree growth at both sites.

The overall negative correlation to temperature throughout the year can be explained by the fact that plant respiration increases exponentially with increasing temperature (Fitter and Hay 1981) and results in a higher loss of assimilated carbon as a source of energy. A similar trend was found by Clark et al. (2003), who observed highly significantly negative correlation of tree growth deviations with current-year means for daily minimum temperature at a tropical rain forest in Costa Rica.

The overall positive effect of an increase in relative humidity on tree growth (except for the beginning of the growth period in Ondangwa), could be related to a direct physiological influence. Low relative humidity values can cause closure of the stomata and a reduction of the $\mathrm{CO}_{2}$ uptake by the plant. However, the strong negative correlation between monthly temperature and relative humidity values, could also cause the observed continuous opposite effect of both variables on tree growth.

The annual nature of tree rings in B. africana and $P$. angolensis and the possibility of crossdating implies high potential for dendrochronological studies in semi-arid forests in Southern Africa. The correlation between rainfall, temperature, relative humidity and tree growth is obvious and is therefore useful for future investigations on tree growth and climate 
studies. The correlations found here lie in the range of other studies performed in the tropics (Jacoby and D'Arrigo 1990; Stahle et al. 1999; Worbes 1999).

The influence of the El Niño phase of the ENSO phenomenon on climate in Southern Africa, is a decrease in precipitation (Nicholson and Entekhabi 1986; Ropelewski and Halpert 1996) and an increase in temperature (Trenberth and Caron 2000). Conversely, the La Niña phase brings an increase in precipitation. Tree growth in Ondangwa is correlated to the El Niño Southern Oscillation phenomenon (Fig. 8). Both the atmospheric (SOI) and the oceanic (Niño3.4) aspect of the ENSO phenomenon (Kestin et al. 1998) are used in the correlation analysis applied in this study. The response of tree growth to both indices, which are strongly negatively correlated to one another, is consistently opposite over the entire growing season. As the Niño 3.4 index, which is based on sea surface temperatures in the Pacific Ocean, shows positive values during the El Niño phase of the ENSO-cycle (Trenberth and Stepaniak 2001), the observed negative correlations indicate a tree growth decrease during El Niño years and an increase in La Niña years. Tree growth decrease in dry El Niño years thus corresponds to the positive relation between tree-ring width and rainfall (Fig. 6). The effect of both phases is strongest during the mature phase of the phenomenon, which lasts from December until May in southern Africa (Anyamba et al. 2002). Cook (2000) found the strongest correlation between rainfall variance in Southern Africa and SOI in the late rainy season, during the months January to March. Influence of ENSO on tree growth in western Zambia was also found to be strongest during these months (Trouet et al. 2004). The response of tree growth in Ondangwa to Niño3.4 (Fig. 8) reflects this effect, as correlation coefficients drop rapidly after the month of March. This, however, could be due to a statistical bias, caused by the strong multicollinearity in the ENSO data set.

Despite statistical correlations found between rainfall and the ENSO phenomenon, not every El Niño year is dry over southern Africa. The strong El Niño event of 1997/1998 for instance, brought drought to Namibia, but did not influence precipitation patterns over other parts of southern Africa (Anyamba et al. 2002). Regional sea surface temperature conditions in the southwestern Indian Ocean and southern Atlantic Ocean may lie at the base of this spatial inconsistency, as they regionally can modify or dampen the precipitation anomaly patterns related to the ENSO phenomenon (Anyamba et al. 2002; Jury and Engert 1999). The correlations found between the Ondangwa chronology and both ENSO indices and the Southern Atlantic Ocean SST anomalies (whereas no correlations were found with the Katima Mulilo chronology), confirm this statement. 
The master chronologies built for Ondangwa and Katima Mulilo present a similar spectral character, both showing a power spectrum peak at a frequency of approximately 0.15 . The explanation for this peak, which corresponds to a cycle of approximately 6.7 years, could be either climatological, physiological or external. All directly-influencing climate variables (rainfall, temperature and relative humidity) were found to show no or only low-amplitude, high-frequency $(0.35-0.4)$ spectral peaks and can thus not explain the spectral pattern in the chronologies. The peak corresponding to a period of 6.7 year does fall in the broad spectral peak corresponding to 2 to 8 years, which characterizes the variability of ENSO-related timeseries (Rasmusson and Carpenter 1982) and could thus be attributed to the ENSO phenomenon. However, Wang and Wang (1996) found that this variability is not distributed evenly over time (1880-1990), but rather concentrated at different frequencies at different times. It is unlikely that the phenomenon, having a varying periodicity over the same time period as the length of the chronologies, would generate a singular and strong peak for both chronologies. The second spectral peak found in the Ondangwa chronology, corresponding to a period of 3.6 years, accurately reflects the power spectra of coral reefs in the Niño 3.4 region (Cole et al. 1993; Urban et al. 2000), which show a very similar periodicity. Remarkable is the appearance of this second peak in the Ondangwa chronology (which showed correlations to the Niño3.4 time series in the correlation analysis) but not in the Katima Mulilo chronology (which did not correlate to the Niño3.4 time series). However, as this peak occurs at a frequency approximately double of the major peak's frequency, it could also be a second harmonic of the same signal. A second possible, and maybe more plausible, explanation for the 6.7 year periodicity, could be a physiological one. As the chronologies at both sites are built based on the same tree species, the physiology of these species (e.g. the occurrence of mast years) could invoke a low frequency signal in the tree growth. Little is known, however, on the specific physiology of the two species studied and of dry tropical trees in general (Borchert 1994; Lawton 1978; Shackleton 2002). A third cause for the found periodicity could be an external one, as the vegetation at both sites is known to be regularly prone to insect outbreaks and fires. The periodicity of these external factors, however, is difficult to verify as no archives are available. Fire (and insect) scars were visible on several samples taken for this study and could be investigated on this behalf.

Overall our results show that as crossdating among different species was possible for both sites, a common influence on a regional scale can be considered. The significant response of tree growth to climate variables underlines this statement. Our results yield 
additional indication for the notion that tropical trees are sensitive to variation in climate patterns. Both tree species are a source of reliable tree-ring data, which reflect sensitivity to climate.

\section{ACKNOWLEDGMENTS}

E. Fichtler was sponsored by the Scholarship Programme of the German Federal Environmental Foundation (DBU). V. Trouet was financed by a grant from the Institute for the Promotion of Innovation by Science and Technology in Flanders (IWT). The samples were provided by the Directorate of Forestry of the Republic of Namibia in the frame of a Namibia-Finland Forestry Programme. We are grateful for the precipitation data provided by Sharon E. Nicholson. We thank F. De Ridder for his help in executing the spectral analysis and finally two anonymous reviewers for their valuable comments. 


\section{REFERENCES}

Anyamba A, Eastman JR (1996) Interannual variability of NDVI over Africa and its relation to El Niño/Southern Oscillation. International Journal of Remote Sensing 17:25332548

Anyamba A, Tucker CJ, Mahoney R (2002) From El Niño to La Niña. Vegetation response patterns over East and Southern Africa during the 1997-2000 period. Journal of Climate 15:3096-3103

Baillie MGL, Pilcher JR (1973) A simple cross dating program for tree-ring research. TreeRing Bulletin 33:7-14

Barnard GA (1963) Comment on `The Spectral Analysis of Point Processes' by M. S. Bartlett, Journal of the Royal Statistical Society, Series B 25, 294p

Borchert R (1994) Water status and development of tropical trees during seasonal drought. Trees 8:115-125

Borchert R (1999) Climatic periodicity, phenology, and cambium activity in tropical dry forest trees. IAWA Journal 20:239-247

Bradley RS, Jones PD, Jouzel, J (1996) Climatic variations and mechanisms of the last 2000 years. Springer Verlag, Berlin.

Clark DA, Piper SC, Keeling CD, Clark DB (2003) Tropical rain forest growth and atmospheric carbon dynamics linked to interannual temperature variation during 19842000. Proceedings of the National Academy of Sciences of the United States of America 100:5852-5857

Coates Palgrave K (1997) Trees of Southern Africa. Struik Publishers (Pty) Ltd., Cape Town $959 \mathrm{p}$

Cole JE, Fairbanks RG, Shen GT (1993) Recent variability in the Southern Oscillation. Isotopic results from a Tarama Atoll coral. Science 260:1790-1793.

Cook ER (1992) Using tree rings to study past El Niño/Southern Oscillation influences on climate. In: Diaz FH, Markgraf V (eds). El Niño: Historical and paleoclimatic aspects of the Southern Oscillation. Cambridge University Press, New York pp 203-214

Cook ER, Briffa K (1990) Data analysis. In: Cook ER, Kairiukstis (eds) Methods of Dendrochronology, Applications in the Environmental Science. Kluwer Acad. Publ., Dordrecht, Boston, London pp 97-162

Cook KH (2000) The South Indian Convergence Zone and interannual rainfall variability over southern Africa. Journal of Climate 13:3789-3804 
D’Arrigo RD, Jacoby GC (1992) A tree-ring reconstruction of New Mexico winter precipitation and its relation to El Niño Southern Oscillation events. In: Diaz FH, Markgraf V (eds) El Niño: Historical and paleoclimatic aspects of the Southern Oscillation. Cambridge University Press, New York, pp 243-257

Eckstein D, Ogden J, Jacoby GC, Ash J (1981) Age and growth rate determination in tropical trees: The application of dendrochronological methods. In: Bormann FH, Berlyn G (eds) Age and Growth Rate of Tropical Trees: New Directions for Research. Yale University, School of Forestry and Environmental Studies, Bull. No. 94:83-106

Elsner JB, Tsonis AA (1996) Singular Spectrum Analysis, Plenum Press, 164p

Enquist BJ, Leffler AJ (2001) Long-term tree ring chronologies from sympatric tropical dry forest trees: individualistic response to climate variation. Journal of Tropical Ecology $17: 41-60$

Fauchereau N, Trzaska S, Rouault M, Richard Y (2003) Rainfall variability and changes in Southern Africa during the 20th century in the global warming context. Natural Hazards 29:139-154

February EC (2000) Archaeological charcoal and dendrochronology to reconstruct past environments of Southern Africa. South African Journal of Science: 96:111-116

Fitter AH, Hay RKM (1981) Environmental Physiology of Plants, Academic Press, London

Goldsmith B, Carter DT (1981) The indigenous timbers of Zimbabwe. The Zimbabwe Bulletin of Forestry research 9, 406p

Gourlay ID (1995) Growth ring characteristics of some African Acacia species. Journal of Tropical Ecology 11:121-140

Jacoby GC, D’Arrigo RD (1990) Teak (Tectona grandis L.F.), a tropical species of large-scale dendroclimatic potential. Dendrochronologia 8:83-98

Jalilvand H, Jalali SG, Akbarnia M, Tabari M, Hosseini SM (2001) Growth response of eight hardwood species to current and past climatic variations using regression models. J. Agric. Sci. Technol. 3:209-225

Jenkins GM, Watts DG (1968) Spectral Analysis and Its Applications. Holden-Day, SanFrancisco.

Jury MR, Engert S (1999) Teleconnections modulating inter-annual climate variability over Northern Namibia. International Journal of Climatology 19:1459-1475

Kestin TS, Karoly DJ, Yano JI, Rayner NA (1998) Time-frequency variability of ENSO and stochastic simulations. Journal of Climate 11:2258-2272 
Lawton RM (1978): A study of the dynamic ecology of Zambian Vegetation. Journal of Ecology 66:175-198

Nicholson SE (2001) A semi-quantitative, regional precipitation data set for studying African climates of the nineteenth century, part I. Overview of the data set. Climatic change $50: 317-353$

Nicholson SE, Entekhabi D (1986) The quasi-periodic behavior of rainfall variability in Africa and its relationship to the Southern Oscillation. Arch. Meteor. Geoph. Bioklimatol. A34:311-348

Pilcher JR (1990) Sample preparation, cross-dating and measurement. In: Cook ER, Kairiukstis LA (eds) Methods of Dendrochronology, Applications in the Environmental Science. Kluwer Academic Publ., Dordrecht, Boston, London pp 40-51 Pumijumnong N (1999) Climate-growth relationships of teak (Tectona grandis L.) from Northern Thailand. In: Vetter RE, Wimmer R (eds) Tree ring analysis: Biological, methodological and environmental aspects. CAB International, Wallingford, Oxon, UK, pp 155-168

Rasmusson EM, Carpenter TH (1982) Variations in tropical sea surface temperature and surface wind fields associated with the Southern Oscillation/El Niño. Monthly Weather Review 110:354-384

Rinn F, Jäkel S (1997) TSAP, Reference Manual. Heidelberg, Germany.

Ropelewski CF, Jones PD (1987) An extension of the Tahiti-Darwin Southern Oscillation Index. Monthly Weather Review 115:2161-2165

Ropelewski CF, Halpert MS (1996) Quantifying Southern Oscillation - precipitation relationships. Journal of Climate 9:1043-1059

Rutherford MC (1983) Growth-rates, biomass and distribution of selected woody plant-roots in Burkea-africana Ochna-pulchra-savanna. Vegetatio 52:45-63

Schweingruber FH (1988) Tree rings. Basics and Applications of Dendrochronology. Dordrecht, Reidel Publ. 276p

Shackleton CM (2002) Growth patterns of Pterocarpus angolensis in savannas of the South African lowveld. Forest Ecology and Management 5723:1-13

Shulze R, Meigh J, Horan M (2001) Present and potential future vulnerability of Eastern and Southern Africa hydrology and water resources. South African Journal of Science $67: 150-160$ 
Stahle DW, Cleaveland MK, Haynes GA, Klimowicz J, Ngwenya P, Mushove P (1996) Preliminary tree-ring investigations of indigenous trees in Zimbabwe. In: Mushove PT, Shumba EM, Matose F (eds) Sustainable management of indigenous forests in the dry tropics, Proceedings of an International Conference in Kadoma, Zimbabwe, May 1996. Forestry Commision, Harare pp 57-61

Stahle DW, Mushove PT, Cleaveland MK, Roig F, Haynes GA (1999) Management implications of annual rings in Pterocarpus angolensis from Zimbabwe. Forest Ecology and Management 124:217-229

Storrs AEG (1995) Know Your Trees, Some of the Common Trees Found in Zambia. Regional Soil Conservation Unit, Zambia, 380p

Trenberth KE, Caron JM (2000) The Southern Oscillation revisited: Sea level pressures, surface temperatures, and precipitation. Journal of Climate, 13:4358-4365

Trenberth KE, Stepaniak DP (2001) Indices of El Niño evolution. Journal of Climate $14: 1697-1701$

Trouet V, Haneca K, Coppin P, Beeckman H (2001) Tree ring analysis of Brachystegia spiciformis and Isoberlinia tomentosa: evaluation of the ENSO-signal in the miombo woodland of eastern Africa. IAWA Journal 22:385-399

Trouet V, Coppin P, Beeckman H (2004) Patterns of annual rings in Brachystegia trees of the Miombo Woodland reveal climatic influence. Biotropica (submitted).

Urban FE, Cole JE, Overpeck JT (2000) Influence of mean climate change on climate variability from a 155 year tropical Pacific coral record. Nature 407:989-993

Vermeulen WJ (1990) A Monograph on Pterocarpus angolensis. SARCCUS Standing Committee for Forestry; Pretoria, South Africa

Vetter RE, Botosso RC (1989) Remarks on age and growth rate determination of Amazonian trees. IAWA Journal 10:133-146

Wang B, Wang Y (1996) Temporal structure of the Southern Oscillation as revealed by waveform and wavelet analysis. Journal of Climate 9:1586-1598

Worbes M (1995) How to measure growth dynamics in tropical trees - A review. IAWA Journal 16:337-351

Worbes M (1999) Annual growth rings, rainfall-dependent growth and long-term growth patterns of tropical trees from the Caparo Forest Reserve in Venezuela. Journal of Ecology 87:391-403 
Worbes M (2002) One hundred years of tree ring research in the tropics- a brief history and an outlook to future challenges. Dendrochronologia 20:217-231

Yadav RR, Singh J (2002) Tree ring analysis of Taxus baccata from the western Himalaya, India and its dendroclimatic potential. Tree-Ring Research 58:23-29 


\title{
4 STABLE CARBON ISOTOPE TIME SERIES FROM TROPICAL TREE RINGS INDICATE A PRECIPITATION SIGNAL
}

\author{
ESTHER FiCHTLER, GERHARD HELLE AND MARTIN WORBES
}

PUBLISHED IN:

Tree Ring Research, Volume 66 (2010), Number 1, Pages 35-49

\begin{abstract}
Although studies on stable-carbon isotopes in trees from temperate zones provide abundant paleoclimatic data, tropical trees are still understudied in this context. Therefore this study examined the variability of intra- and inter-annual carbon isotopic pattern in several tree species from various tropical climates. The $\delta^{13} \mathrm{C}$ values of samples of 12 broadleaved trees (seven species) from various paleo- and neotropical sites along a climatic moisture gradient were investigated. The inter-annual variability between species and sites was studied. Further the relationship between $\delta^{13} \mathrm{C}$ and precipitation time series was analyzed. Results show that tropical tree species show a similar variability in carbon isotopic composition as temperate tree species. Significant correlations between annual precipitation and tree-ring $\delta^{13} \mathrm{C}$ time series were negative. Successful crossdating of a tree-ring $\delta^{13} \mathrm{C}$ time series highlights the potential of carbon isotope measurements for tropical tree-ring analytical studies. Tropical broadleaved trees are able to capture a carbon isotopic signal in their annual rings even under everwet conditions and show good potential for paleoclimatic research.
\end{abstract}




\section{INTRODUCTION}

The analysis of responses of trees to changing climate is a current challenge in global environmental research. A powerful and appropriate tool is the interpretation of tree-ring parameters, like ring width, wood density or stable isotopes. Because of annually recurring periods of slow growth or dormancy, wood anatomical differences appear as annual rings in cross-sections of tree stems. Tree-ring features and their variability store information on past growth conditions and can therefore contain paleoclimatic information. Many studies have proven the existence of annual rings in tree species in tropical regions from arid zones (Gourlay 1995; Stahle et al. 1999; Fichtler et al. 2004; Trouet et al. 2006) to humid zones (Fichtler et al. 2003), mangroves (Menezes et al. 2003; Verheyden et al. 2004a) and swamps (Callado et al. 2001). They all showed that rings in tropical trees appear with similar anatomical structures, as rings in temperate tree species, caused by periods of slow growth caused by the periodicity of rainfall events. Unlike in temperate zones, relatively few applications were developed for tropical regions (Worbes et al. 2003; Schöngart et al. 2004, 2006; Brienen and Zuidema 2005, 2006), despite numerous reports on the potential of treering analysis in tropical trees (Worbes 2002 and citations therein). Inter alia, this is caused by limited technical facilities and financial resources in tropical countries themselves, but also difficult-to-access stands, low sampling replication because of the enormous species diversity that comes along with low abundances of individuals of any particular species in most tropical forests. Furthermore, standard methods like coring, are not suitable for most tropical trees, easily accessible forest stands are often protected, and exportation of wood discs is subject to strict regulations or even prohibited.

Studies on stable-carbon isotopes in the wood of temperate tree species have reported that the fractionation of ${ }^{13} \mathrm{C}$ in $\mathrm{C}_{3}$ plants varies with water stress (Ehleringer and Cooper 1988), solar radiation (Ehleringer et al. 1986), and plant nutrition (Livingston et al. 1999). These variations were studied on an inter-annual base, using tree rings as records of the past, with special regards to their relation to climate (Leavitt and Long 1989, 1991; Danis et al. 2006; Gagen et al. 2006) and the possibility of using tree-ring stable-carbon time series as proxies for climate reconstruction. Dendroclimatology in the tropics is yet in an early stage, although paleoclimatic records from tropical regions are essential to our understanding of past changes in the Earth's climatic system, equator-to-pole linkages, and the prediction of sensitivity of tropical regions to future climate change (Robertson et al. 2006). 
The content of ${ }^{13} \mathrm{C}$ in wood tissue of $\mathrm{C}_{3}$ plants is described as a function of (1) the fractionation caused by diffusion of $\mathrm{CO}_{2}$ through the stomata and by enzymatic $\mathrm{CO}_{2}$ fixation, (2) the ratio of the intercellular to atmospheric $\mathrm{CO}_{2}$ concentration, and (3) the source value, given by the isotopic composition of atmospheric $\mathrm{CO}_{2}$ (Farquhar et al. 1989). Accordingly, leaves use internal $\mathrm{CO}_{2}$ for photosynthetic processes and, when stomatal closure takes place because of lack of moisture, the $\mathrm{CO}_{2}$ fixing enzyme discriminates less against ${ }^{13} \mathrm{C}$ in relation to the generally preferred ${ }^{12} \mathrm{C}$. This results in a higher (less negative) $\delta^{13} \mathrm{C}$ value of organic matter. As tropical trees undergo the same photosynthetic mechanisms, a carbon isotopic signal reflecting varying hydroclimatic conditions should be stored in their annual increments. Very few studies on the stable-carbon isotope composition of tropical wood with restricted geographical extensions have been published (Tarhule and Leavitt 2004, Verheyden et al. 2004b; Hietz et al. 2005; Robertson et al. 2006; Gebrekirstos et al. 2009). In the present study the stable-carbon isotope ratios in wood from Terminalia tree species, and for comparison two other species, growing under different precipitation regimes from 675 to $4015 \mathrm{~mm}$ mean annual precipitation and annually recurring dry periods ranging from zero to seven months were investigated. The objectives of the present study were a) to examine the intra- and interannual variability of carbon isotope ratios along a moisture gradient, and b) to test whether or not an annual precipitation signal is contained within the carbon isotope series.

\section{MATERIAL AND MethodS}

STUDY SPECIES AND SITES A total of 12 discs, originating from the collection of tropical stem discs of the Department of Crop Sciences, Agronomy in the Tropics, University of Göttingen, Germany, were included in the study. For all discs, information on felling date and site conditions exist. To test the sensitivity of tree species to drought, trees within one taxon, the genus Terminalia LiNN (family Combretaceae), were chosen from sites along a moisture gradient from very arid to perhumid (Table 1a). To test species specific adaptations, two different species (Cedrela odorata, Swietenia macrophylla) of the family Meliaceae were added to the sample set. To compare the overall mean values of $\delta^{13} \mathrm{C}$ of tree individuals with the general hydroclimatic conditions at the sites, the $\delta^{13} \mathrm{C}$ the co-results from earlier radiocarbon datings for nine tree individuals (Fichtler et al. 2003, Worbes 1999a) were added to the sample set (cf. Table 1b). 
Table 1 Information on sampling sites and species for stable carbon isotope analyses (a) and radiocarbon dating (b); $\mathrm{OD}=$ obligate deciduous, $\mathrm{EG}=$ evergreen.

a)

\begin{tabular}{|c|c|c|c|c|c|c|c|c|}
\hline Site & $\begin{array}{c}\text { Geo- } \\
\text { graphical } \\
\text { position }\end{array}$ & $\begin{array}{c}\text { Mean } \\
\text { annual } \\
\text { rainfall in } \\
\mathrm{mm}\end{array}$ & $\begin{array}{l}\text { Length } \\
\text { of dry } \\
\text { period } \\
\text { in } \\
\text { months }\end{array}$ & $\begin{array}{l}\text { species } \\
\text { sampled }\end{array}$ & $\begin{array}{c}\text { Pheno } \\
\text {-logy } \\
\text { of } \\
\text { trees }\end{array}$ & Tree Code & $\begin{array}{l}\text { No. of } \\
\text { rings } \\
\text { samp- } \\
\text { led }\end{array}$ & $\begin{array}{c}\text { Years } \\
\text { climate } \\
\text { data } \\
\text { avail- } \\
\text { able }\end{array}$ \\
\hline $\begin{array}{c}\text { Katima } \\
\text { Mulilo }\end{array}$ & $\begin{array}{l}17^{\circ} 30^{\prime} \mathrm{S}, \\
24^{\prime} 17^{\circ} \mathrm{E}\end{array}$ & 675 & $6-7$ & T. sericea & OD & Terse 43 & 9 & 9 \\
\hline (Namibia) & & & & T. sericea & OD & Terse 34 & 11 & 11 \\
\hline $\begin{array}{c}\text { Dorado- } \\
\text { Tumeremo } \\
\text { (Venezuela) }\end{array}$ & $\begin{array}{l}06^{\circ} 55^{\prime} \mathrm{N} \\
61^{\circ} 24^{\prime} \mathrm{W}\end{array}$ & 1560 & $2-3$ & T. amazonia & $E G$ & Teram 621 & 21 & 21 \\
\hline & $\begin{array}{l}04^{\circ} 40^{\prime} \mathrm{N}, \\
11^{\circ} 32^{\prime} \mathrm{E}\end{array}$ & 1570 & $2-4$ & T. superba & OD & Tersu 753 & 10 & 6 \\
\hline (Cameroon) & & & & & OD & Tersu 584 & 87 & 31 \\
\hline & $\begin{array}{l}07^{\circ} 26^{\prime} \mathrm{N}, \\
70^{\circ} 55^{\prime} \mathrm{W}\end{array}$ & 1750 & $2-4$ & T. guyanensis & $E G$ & Tergu 455 & 13 & 13 \\
\hline \multirow[t]{3}{*}{ (Venezuela) } & & & & & $E G$ & Tergu 756 & 29 & 29 \\
\hline & & & & C. odorata & OD & Cedod 754 & 22 & 22 \\
\hline & & & & S. macrophylla & OD & Swima 230 & 10 & 10 \\
\hline $\begin{array}{c}\text { Km } 98 \\
\text { Sierra de } \\
\text { Lema } \\
\text { (Venezuela) }\end{array}$ & $\begin{array}{l}06^{\circ} 06^{\prime} \mathrm{N}, \\
61^{\circ} 23^{\prime} \mathrm{W}\end{array}$ & 2975 & $1-2$ & T. amazonia & $E G$ & Teram 628 & 24 & 19 \\
\hline $\begin{array}{c}\text { Uriman } \\
\text { (Venezuela) }\end{array}$ & $\begin{array}{l}05^{\circ} 60^{\prime} \mathrm{N}, \\
62^{\circ} 65^{\prime} \mathrm{W}\end{array}$ & 3890 & $1-2$ & T. quintalata & $E G$ & Terqu 453 & 27 & 23 \\
\hline $\begin{array}{c}\text { La Selva } \\
\text { (Costa Rica) }\end{array}$ & $\begin{array}{l}10^{\circ} 26^{\prime} \mathrm{N}, \\
83^{\circ} 59^{\prime} \mathrm{W}\end{array}$ & 4015 & $0-1$ & T. amazonia & $E G$ & Teram 445 & 14 & 14 \\
\hline
\end{tabular}

b)

\begin{tabular}{|c|c|c|c|c|}
\hline Site & $\begin{array}{l}\text { Geographical } \\
\text { position }\end{array}$ & $\begin{array}{l}\text { Mean } \\
\text { annual } \\
\text { rainfall } \\
\text { in } \mathrm{mm}\end{array}$ & $\begin{array}{l}\text { Length } \\
\text { of dry } \\
\text { period } \\
\text { in } \\
\text { months }\end{array}$ & species sampled \\
\hline \multirow{3}{*}{$\begin{array}{c}\text { Gran Sabana } \\
\text { (Venezuela) }\end{array}$} & $05^{\circ} 06^{\prime} \mathrm{N}, 60^{\circ} \mathrm{W}$ & 1880 & $0-4$ & Sapotaceae (Juss.) \\
\hline & & & & Ficus sp. (L.) \\
\hline & & & & Manilkara sp.( Adans.) \\
\hline \multirow{6}{*}{$\begin{array}{c}\text { La Selva } \\
\text { (Costa Rica) }\end{array}$} & $10^{\circ} 26^{\prime} \mathrm{N}, 8^{\circ}{ }^{\circ} 59^{\prime} \mathrm{W}$ & 4015 & $0-1$ & Simarouba amara (Aubl.) \\
\hline & & & & Balizia elegans ((Ducke) Barneby \& J.W. Grimes) \\
\hline & & & & Dipteryx panamensis ((Pittier) Record \& Mell) \\
\hline & & & & Hymenolobium mesoamericanum (H.C. Lima) \\
\hline & & & & Minquartia guianesis (Aubl.) \\
\hline & & & & Pentaclethra macroloba (Kuntze) \\
\hline
\end{tabular}


Details on sites and species are listed in Table 1a. Katima Mulilo, Namibia, represents the driest site of the sample set with a mean annual precipitation of $675 \mathrm{~mm}$ and a dry period (monthly precipitation $<50 \mathrm{~mm}$ ) lasting up to seven months. The most humid site is La Selva, Costa Rica, with a mean annual precipitation of $4015 \mathrm{~mm}$ and a dry period of one month or less. For all sampling sites, monthly precipitation data from nearby meteorological stations were available for periods covering (at least parts of) the tree's life span. Monthly data for Katima Mulilo, Namibia, were provided by S. Nicholson (Meteorology Department, Florida State University; pers. communication). The data for Dorado-Tumeremo, Venezuela, were available from the CVG-EDELCA División de Cuencas e Hidrología. For Biakoa, Cameroon, a mean precipitation data set was built out of time series for Bafia and Yaounde, for which data were derived from the KNMI climate explorer (Oldenborgh and Burgers 2005). For km 98 Sierra de Lema, Venezuela, data were available from MARNR Dirección de Hidrología y Metereología, the data for Caparo and Uriman, Venezuela, were adopted from earlier treering studies on these sites (Ortiz et al. 2006; Worbes 1999b). Finally, monthly precipitation data for La Selva, Costa Rica, were provided by the Organization of Tropical Studies (OTS 2007).

Two individuals of Terminalia sericea BuRCH EX DC from Katima Mulilo, Namibia, one juvenile and one mature tree, were analyzed. T. sericea is drought-deciduous and forms well-defined annual rings, defined by a marginal parenchyma band and variations in vessel density and size (Figure 1a). Individual trees belonging to the species Terminalia amazonia EXELL were analyzed from each of three sites, Dorado-Tumeremo, Venezuela, km 98 Sierra de Lema, Venezuela, and La Selva, Costa Rica, respectively. T. amazonia is evergreen and forms annual tree rings defined by either fiber cell density variations, variation of vessel density and size, marginal parenchyma bands or a combination of two or more of these characteristics (Figure 1b). Two individuals of Terminalia superba ENGL. \& DIELS from Biakoa, Cameroon, were analyzed. T. superba is drought deciduous and the distinct rings are defined by a delimiting marginal parenchyma band (Figure 1c). From Caparo, Venezuela, one individual of Cedrela odorata LINN and Swietenia macrophylla KING, respective, as well as two individuals of Terminalia guyanensis EICHLER were sampled. $C$. odorata and $S$. macrophylla are obligately deciduous, while T. guyanensis is evergreen. All four individuals show well-defined tree rings, defined by delimiting marginal parenchyma bands in C. odorata and S. macrophylla (Figures $1 \mathrm{~d} \& \mathrm{e}$ ) and alternating patterns of parenchyma and fiber bands in T. guyanensis (Figure 1f). One individual of Terminalia quintalata MAGUIRE was sampled at Uriman, Venezuela. T. quintalata forms annual rings characterized by fiber cell density 
variations and an ambiguous band of fiber cells with smaller, fewer or no vessels, rather than a sharp and distinct boundary (Figure 1g).
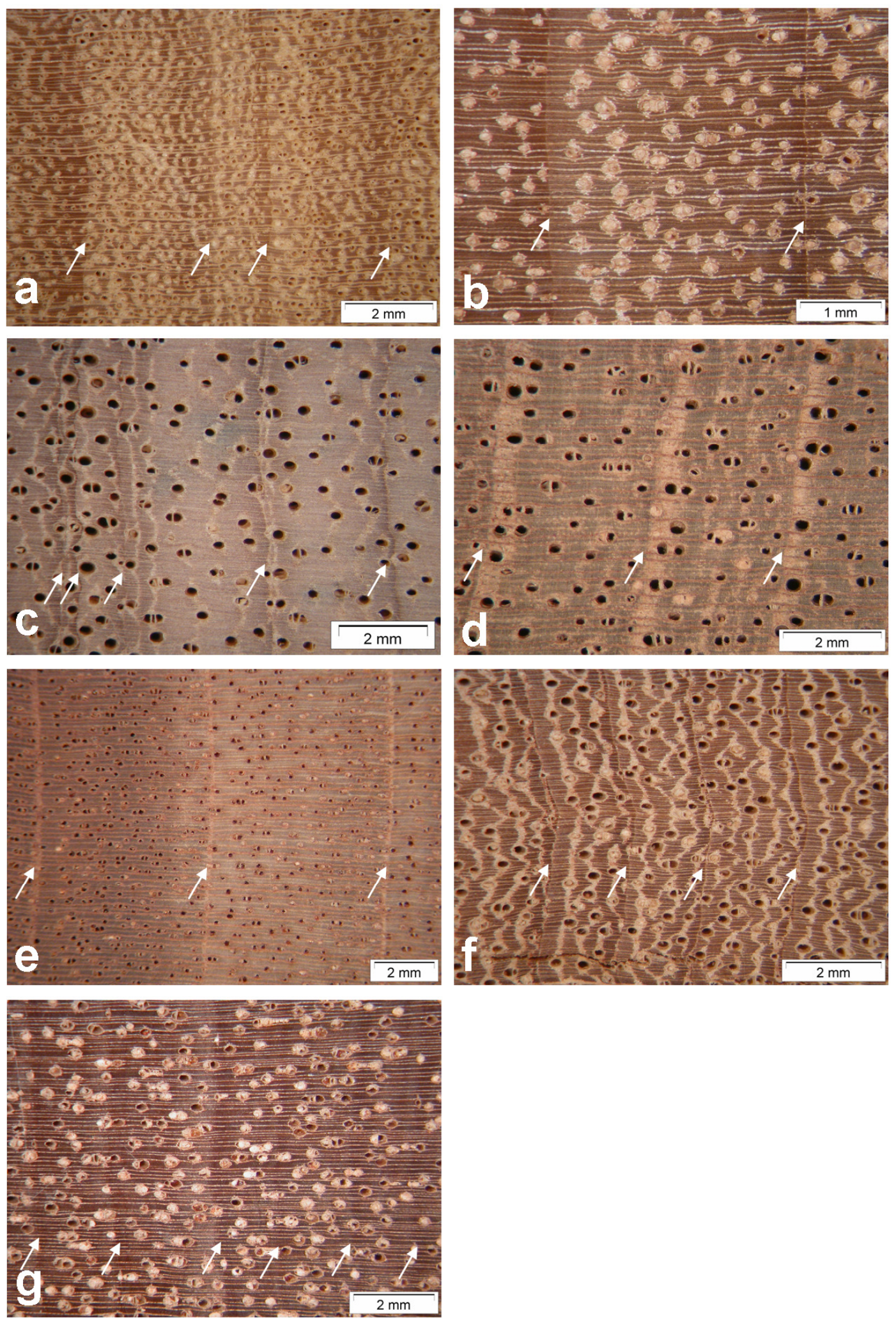

Fig 1 Sanded wood surfaces of sampled species: T. sericea (a), T. amazonia (b), T. superba (c), C. odorata (d), S. macrophylla (e), T. guyanensis (f) and T. quintalata (g). Pictures show tree rings (growing direction from left to right), white arrows indicate ring boundaries 
SAMPLE PREPARATION AND ISOTOPE MEASUREMENTS The stem discs were polished with sand paper up to grit 600 , and tree-ring boundaries were marked. Because felling dates were known, tree rings were dated by counting. For $C$. odorata 22 rings were analyzed with a very fine resolution at the Institute of Chemistry and Dynamics of the Geosphere, Research Centre Jülich, Germany, following the sample preparation and measurements as described in Helle and Schleser (2004). For 11 discs, a section of one radius with clearly visible rings (with lengths between 9 and 87 years depending on the species) was defined for $\delta^{13} \mathrm{C}$ sampling. These radii were intra-annually sub-sampled with a medium resolution, using a twist drill (Micromat 40E, Proxxon, Germany) with a bit of $0.8 \mathrm{~mm}$ width that produced homogeneous wood powder. Samples were weighed and filled into tin capsules for stable isotope ratio mass spectrometry. Bulk wood samples were used, as recent studies on isotopic differences of bulk wood and wood components report only little or no differences in the variability of the carbon isotope signal (Loader et al. 2003; Borella et al. 1998; van de Water 2002). The stable carbon isotope ratio was measured on line using an NA 2500 elemental analyzer (CE Instruments, Italy) with an isotope ratio mass spectrometer MAT Delta plus (Finnigan MAT, Germany) via a Con Flo III interface at the Centre for Stable Isotope Research and Analysis, Forest Ecosystem Research, University of Göttingen, Germany. All results are given in $\delta$-notation, i.e. the relative deviation from the PDB (Pee Dee Belemnite) standard:

$$
\delta^{13} \mathrm{C}=\left(R_{\text {sample }} / R_{\text {standard }}-1\right) \times 1000,
$$

where $R_{\text {sample }}$ and $R_{\text {standard }}$ are the ${ }^{13} \mathrm{C} /{ }^{12} \mathrm{C}$ ratios in a sample and standard, respectively.

STATISTICAL ANALYSIS For each of the inter-annual analyses the high- and medium resolution measurements were averaged for the consecutive years as the tropical hardwood species used show only little or no density gradient within the rings. All annual series were detrended as the difference of the individual values from a linear regression of the entire series. For the detrended $\delta^{13} \mathrm{C}$ time series, correlation analyses were performed for either trees of the same species or individuals from the same sites. Further, the different $\delta^{13} \mathrm{C}$ time series were compared based on their Gleichläufigkeitskoeffizient (GLK), which is a measure of the year-to-year concurrence between the interval trends of two time series based upon the sign of concurrence (Kaennel and Schweingruber 1995). The GLK -value gives the sum of equal slope intervals in \%.

Annual precipitation time series from nearby stations were built and detrended corresponding to the respective "growth year". For stations in the northern hemisphere this is the sum of precipitation of all months from January to December, whereas for the site in the 
southern hemisphere the sum of all months from August of the previous year to July of the current year (Walter and Lieth 1969). All correlation analyses of $\delta^{13} \mathrm{C}$ time series and climatic data sets were performed using Pearson's correlations and judging significance at $\mathrm{P}<0.05$. A minimum overlap period between $\delta^{13} \mathrm{C}$ time series and rainfall time series of 20 years was chosen.

The $\delta^{13} \mathrm{C}$ time series of a T. quintalata (Uriman, Venezuela) with unknown death year was tested for the suitability of these data for dating the tree. The disc of T. quintalata was taken in 1987 from a standing dead tree. Wood was sampled for $\delta^{13} \mathrm{C}$ measurements over a period of 27 years starting at the outermost intact ring towards the center. The time series of annual $\delta^{13} \mathrm{C}$ values were crossdated statistically and visually with annual rainfall time series by moving and matching the $\delta^{13} \mathrm{C}$ time series of the tree along the rainfall time series, starting with the sampling year going backwards in time.

The $\delta^{13} \mathrm{C}$ results from the radiocarbon measurements were derived from cellulose samples and had to be corrected with a factor of $-1.3 \%$ as Harlow et al. (2006) found this value as a mean difference between bulk wood and holocellulose samples in a multi-species comparison of stable-carbon isotope values from different treated wood samples. The mean, maximum and minimum $\delta^{13} \mathrm{C}$ values for the three individuals were correlated with annual mean rainfall conditions at the sampling sites. 


\section{RESULTS}

The high-resolution $\delta^{13} \mathrm{C}$ profile with eight to 186 measurements per ring of the $C$. odorata sample shows a definite annual pattern with lowest values at the ring boundaries (Figure 2). Increasing values at the beginning of the rings are followed by a $\delta^{13} \mathrm{C}$ decrease towards the end of the growth ring. The course and the amplitude of these annual curves vary from year to year. Within-ring variation was highest (2.31\%o) in the year 1968 and lowest $(0.80 \%$ o) in 1977 (Table 2). The overall level also differs among years between $-26.83 \%$ in 1975 and $-28.77 \%$ in 1979 (Table 2).

Table 2 Descriptive statistics for the stable carbon isotope measurements of the 12 sampled trees (all values in \%o)

\begin{tabular}{|c|c|c|c|c|c|c|c|c|c|c|}
\hline \multirow[b]{2}{*}{ ree } & & \multirow[b]{2}{*}{ MEAN } & \multirow[b]{2}{*}{ MIN } & \multirow[b]{2}{*}{ MAX } & \multirow[b]{2}{*}{ Variance } & \multirow[b]{2}{*}{ Std Dev } & \multicolumn{2}{|c|}{$\begin{array}{c}\text { intra-annual } \\
\text { variation }\end{array}$} & \multicolumn{2}{|c|}{$\begin{array}{c}\text { inter-annual } \\
\text { variation }\end{array}$} \\
\hline & ee & & & & & & $\min$ & $\max$ & $\min$ & $\max$ \\
\hline Terse 43 & $\begin{array}{l}\text { (Katima } \\
\text { Mulilo, } \\
\text { Namibia) }\end{array}$ & $-24,70$ & $-25,21$ & $-23,88$ & 0,182 & 0,426 & 0,659 & 2,229 & 0,044 & 1,329 \\
\hline Terse 34 & $\begin{array}{l}\text { (Katima } \\
\text { Mulilo, } \\
\text { Namibia) }\end{array}$ & $-25,90$ & $-26,59$ & $-24,57$ & 0,287 & 0,536 & 0,221 & 2,781 & 0,015 & 2,022 \\
\hline Teram 621 & $\begin{array}{l}\text { (Dorado- } \\
\text { Tumeremo, } \\
\text { Venezuela) }\end{array}$ & $-26,33$ & $-27,41$ & $-25,46$ & 0,217 & 0,466 & 0,071 & 1,025 & 0,006 & 1,954 \\
\hline Tersu 753 & $\begin{array}{l}\text { (Biakoa, } \\
\text { Cameroon) }\end{array}$ & $-23,43$ & $-23,62$ & $-23,19$ & 0,016 & 0,127 & 0,272 & 0,947 & 0,009 & 0,434 \\
\hline Tersu 584 & $\begin{array}{l}\text { (Biakoa, } \\
\text { Cameroon) }\end{array}$ & $-24,08$ & $-25,42$ & $-23,07$ & 0,261 & 0,511 & 0,005 & 1,434 & 0,002 & 2,340 \\
\hline Tergu 455 & $\begin{array}{l}\text { (Caparo, } \\
\text { Venezuela) }\end{array}$ & $-26,55$ & $-26,99$ & $-26,12$ & 0,070 & 0,265 & 0,399 & 1,810 & 0,001 & 0,872 \\
\hline Tergu 756 & $\begin{array}{l}\text { (Caparo, } \\
\text { Venezuela) }\end{array}$ & $-26,96$ & $-30,30$ & $-25,32$ & 1,392 & 1,180 & 0,077 & 2,013 & 0,003 & 4,984 \\
\hline Cedod 754 & $\begin{array}{l}\text { (Caparo, } \\
\text { Venezuela) }\end{array}$ & $-27,92$ & $-28,77$ & $-26,83$ & 0,260 & 0,510 & 0,801 & 2,308 & 0,001 & 1,941 \\
\hline Swima 230 & $\begin{array}{l}\text { (Caparo, } \\
\text { Venezuela) }\end{array}$ & $-27,80$ & $-28,60$ & $-27,40$ & 0,159 & 0,399 & 0,668 & 2,504 & 0,005 & 1,207 \\
\hline Teram 628 & $\begin{array}{l}\text { (Km } 98 \text { Sierra } \\
\text { de Lema, } \\
\text { Venezuela) }\end{array}$ & $-26,41$ & $-27,59$ & $-25,16$ & 0,435 & 0,660 & 0,188 & 1,335 & 0,000 & 2,429 \\
\hline Terqu 453 & $\begin{array}{l}\text { (Uriman, } \\
\text { Venezuela) }\end{array}$ & $-24,78$ & $-25,32$ & $-24,18$ & 0,083 & 0,288 & 0,014 & 0,602 & 0,001 & 1,138 \\
\hline Teram 445 & $\begin{array}{l}\text { (La Selva, } \\
\text { Costa Rica) }\end{array}$ & $-27,99$ & $-29,00$ & $-27,59$ & 0,132 & 0,360 & 0,131 & 0,743 & 0,001 & 1,404 \\
\hline
\end{tabular}




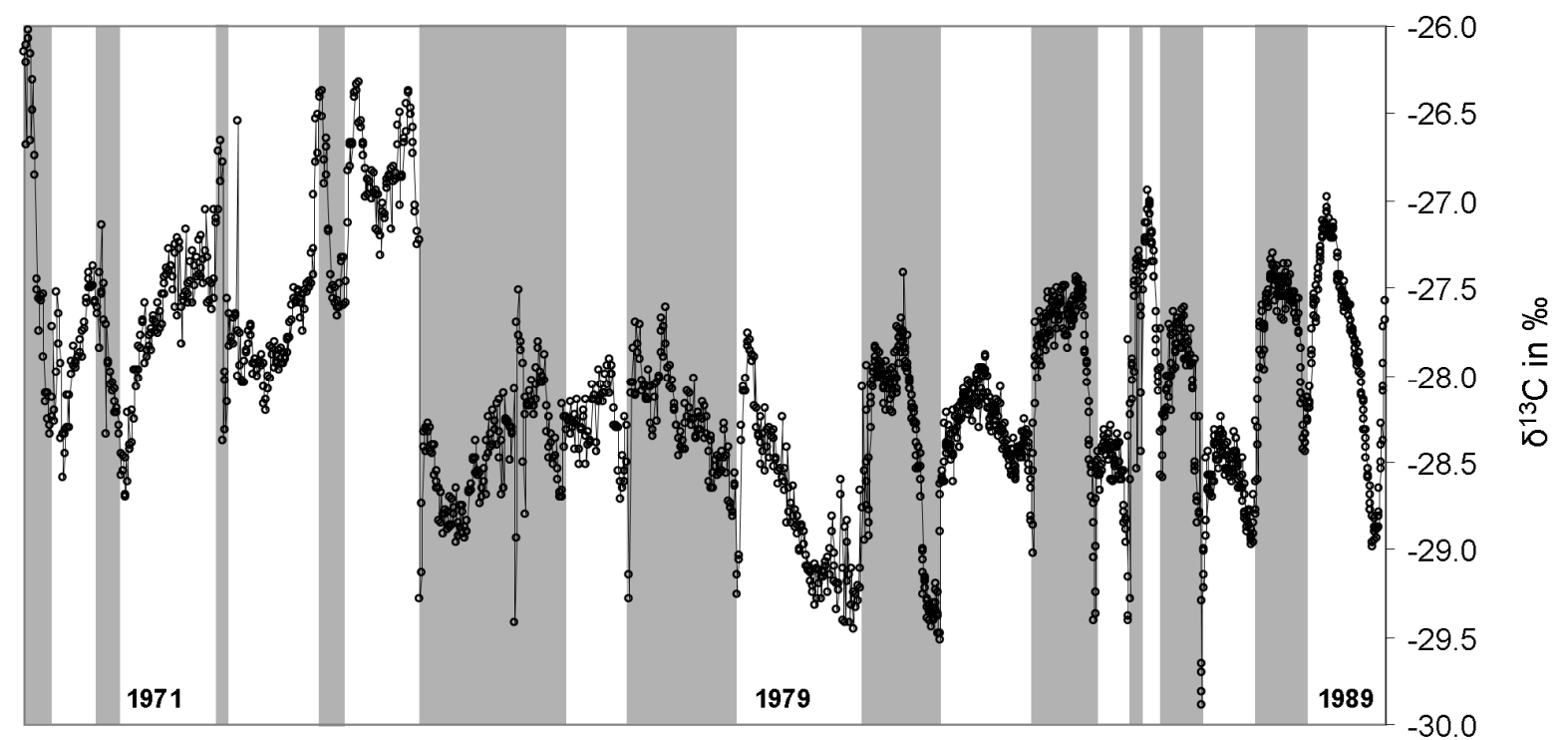

Fig 2 High-resolution $\delta^{13}$ C profile of $C$. odorata from Caparo, Venezuela, for the years 1968-1989; white and gray areas indicate different years.

The medium-resolution $\delta^{13} \mathrm{C}$ profile of the Terminalia species with one to 16 measurements per year also showed the definite pattern observed in the high-resolution profile, for rings that are wide enough to make at least four to six measurements per ring (Figure 3a). In small rings allowing fewer than four measurements per ring, minimum values at the ring boundaries are no longer visible in any ring (Figure $3 b$ ). The course and the amplitude of the intra-annual $\delta^{13} \mathrm{C}$ values are variable in these profiles. The highest intraannual variation ( $c f$. Table 2) was found in T. sericea with $2.78 \%$ (1993) and the lowest variation was found in a ring of $T$. superba with $0.005 \%$ (1974). The radial pattern of mean annual carbon isotopes varied considerably between species and within trees. The minimum variation among different years within individual samples was very low in all individuals, the maximum inter-annual variation spanned between $0.43 \%$ for $T$. superba from Biakoa, Cameroon, and $4.98 \%$ for T. guyanensis from Caparo, Venezuela (Table 2). Annual mean values of all measured samples per tree species fall within the range of $-27.99 \%$ o to $-23.43 \%$ o (Table 2). 

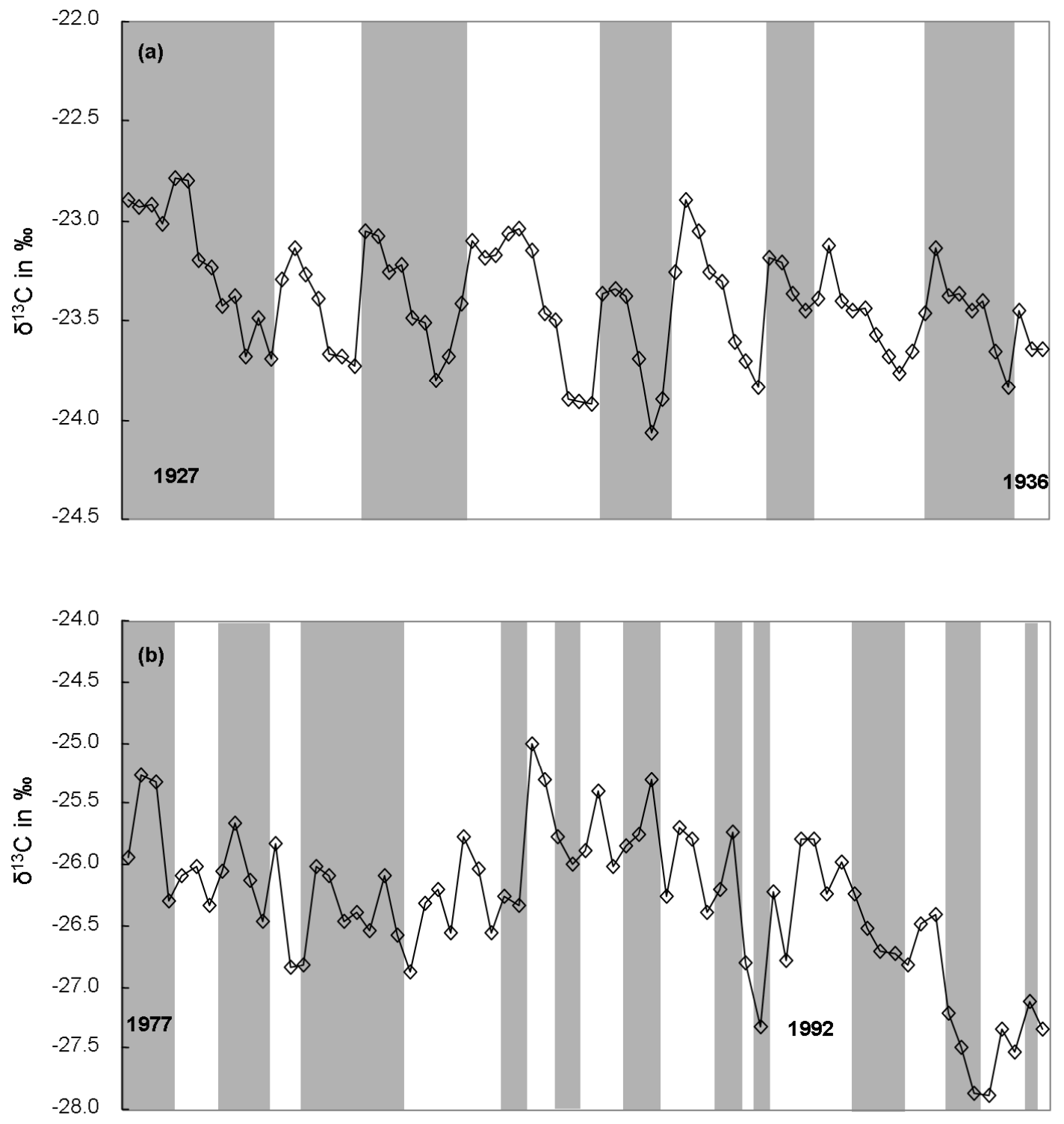

Fig 3 (a) Medium resolution $\delta^{13} \mathrm{C}$ profile of $T$. superba from Biakoa, Cameroon, for the years 19271936, (b) medium resolution $\delta^{13} \mathrm{C}$ profile of T. amazonia from $\mathrm{km} 98$ Sierra de Lema, Venezuela, for the years 1977-1998; white and gray areas indicate different years

The $\delta^{13} \mathrm{C}$ time series of two individual T. sericea trees from the arid site Katima Mulilo, Namibia, show an identical inter-annual $\delta^{13} \mathrm{C}$ pattern (Figure $4 \mathrm{a}$ ). The individual series are significantly correlated $(r=0.89, \mathrm{p}=0.001)$, the GLK of $100 \%$ is significant (Table $3)$. The overall mean $\delta^{13} \mathrm{C}$ is higher in the juvenile tree $(-24.70 \%$ ) than in the mature tree (25.90\%o). The two T. superba samples from Biakoa, Cameroon, also show a similar interannual $\delta^{13} \mathrm{C}$ pattern and are significantly correlated at $\mathrm{r}=0.68, \mathrm{p}=0.030$, and the GLK of $75 \%$ is high (Table 3 , Figure $4 b$ ). 
Table 3 Correlation results for stable carbon isotope time series of trees of the same species and/or from same site.

\begin{tabular}{|c|c|c|c|}
\hline Tree pairs & & $\mathbf{r}$ & GLK \\
\hline Terse 34 vs Terse 43 & (Katima Mulilo, Namibia) & $0.89^{* *}$ & $100^{* *}$ \\
\hline Tersu 584 vs Tersu 584 & (Biakoa, Cameroon) & $0.68^{\star}$ & 75 \\
\hline Cedod 754 vs Swima 230 & (Caparo, Venezuela) & 0.2 & 63 \\
\hline Cedod 754 vs Tergu 455 & (Caparo, Venezuela) & $a$ & $a$ \\
\hline Cedod 754 vs Tergu 756 & (Caparo, Venezuela) & $-0.49^{*}$ & 63 \\
\hline Swima 230 vs Tergu 455 & (Caparo, Venezuela) & $a$ & $a$ \\
\hline Swima 230 vs Tergu 756 & (Caparo, Venezuela) & -0.45 & 43 \\
\hline Tergu 455 vs Tergu 756 & (Caparo, Venezuela) & $0.75^{\star \star}$ & $75^{\star}$ \\
\hline Teram 621 vs Teram 628 & $\begin{array}{l}\text { (Durado-Tumeremo vs Km } 98 \text { Sierra } \\
\text { de Lema, Venezuela) }\end{array}$ & 0.37 & $76^{\star \star}$ \\
\hline Teram 621 vs Teram 445 & $\begin{array}{l}\text { (Durado-Tumeremo, Venezuela vs La } \\
\text { Selva, Costa Rica) }\end{array}$ & 0.47 & 58 \\
\hline Teram 628 vs Teram 445 & $\begin{array}{l}\text { (Km } 98 \text { Sierra de Lema, Venezuela vs } \\
\text { La Selva, Costa Rica) }\end{array}$ & -0.06 & 63 \\
\hline
\end{tabular}

$a=$ no overlap; ${ }^{*} p<0.05 ;{ }^{* *} p<0.01$

Three individual samples of T. amazonia from two sites in Venezuela and one site in Costa Rica covered an overlapping period of 21 years and 14 years, respectively. The individuals from Dorado-Tumeremo and km 98 Sierra de Lema, Venezuela, show similar year-to-year variability patterns expressed by a significant GLK value of $76 \%$ (Table 3). Neither are correlated with the time series of the Costa Rican sample from the same species. The overall mean values of the trees from Venezuela show the same range, but were considerably lower (more negative) in the sample from La Selva, Costa Rica (Figure 4c).

Within the four tree individuals from Caparo, Venezuela, only the two T. guyanensis individuals show a significant correlation and GLK $(r=0.75, p=0.008$; GLK $=75 \%$; Figure 4d). The overall mean $\delta^{13} \mathrm{C}$ levels of the T. guyanensis samples are in the same range, whereas C. odorata and S. macrophylla show lower mean values (Table 2). 

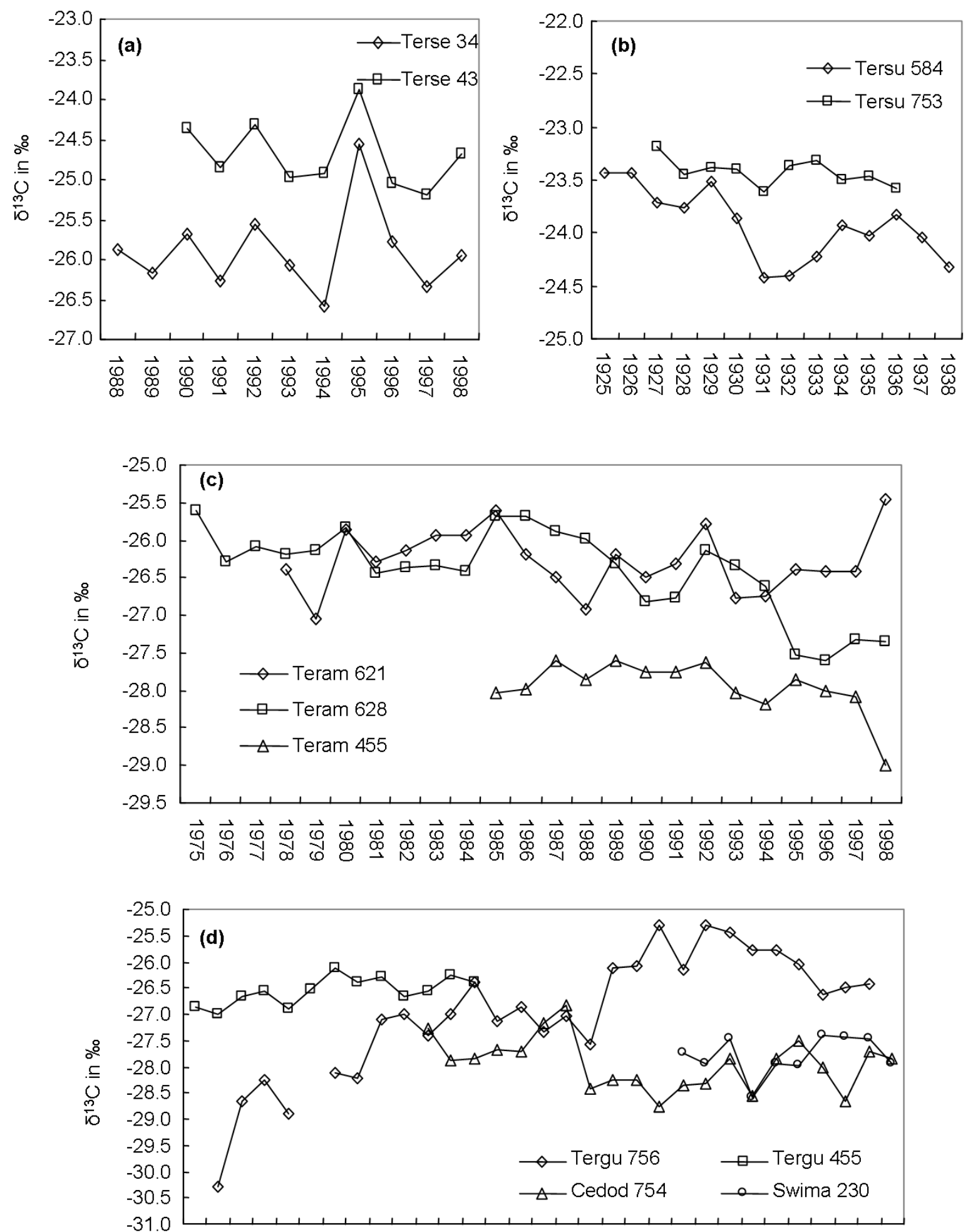

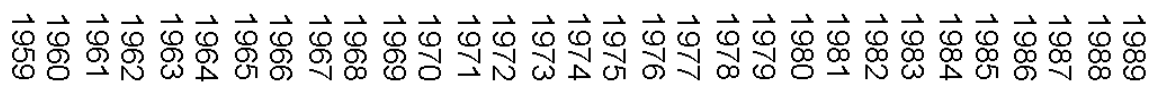

Fig 4 Inter-annual $\delta^{13} \mathrm{C}$ profile of (a) T. sericea (Terse 34 and Terse 43) from Katima Mulilo, Namibia, (b) T. superba (Tersu 584 and Tersu 753) from Biakoa, Cameroon, (c) T. amazonia from DoradoTumeremo (Teram 621) and Km98 Sierra de Lema (Teram 628), Venezuela and La Selva (Teram 445), Costa Rica , and (d) C. odorata (Cedod 754), T. guyanensis (Tergu 455 and Tergu 756) and $S$. macrophylla (Swima 230) from Caparo, Venezuela 
Four series from living trees met the criterion of minimum 20 years overlap between the carbon and precipitation series namely $C$. odorata and $T$. guyanensis from Caparo, Venezuela, T. amazonia from Dorado-Tumeremo, Venezuela, as well as $T$. superba from Biakoa, Cameroon (cf. Table 1). Three out of four show a significant correlation of annual $\delta^{13} \mathrm{C}$ values with annual rainfall series (Table 4). C. odorata is negatively correlated $(\mathrm{r}=-$ $0.59, \mathrm{p}=0.004)$ with annual rainfall (Figure 5a), T. amazonia is negatively correlated $(\mathrm{r}=-$ $0.55, \mathrm{p}=0.009)$ with annual rainfall (Figure $5 \mathrm{~b})$ and $T$. superba is negatively correlated $(\mathrm{r}=-$ $0.44, \mathrm{p}=0.013$ ) with annual rainfall (Figure 5c).

To date the dead sampled T. quintalata tree by means of $\delta^{13} \mathrm{C}$, the time series of the tree was moved statistically along the mean annual precipitation time series and showed only one matching position in time. Dating the first analyzed ring to 1980 resulted in a significant and strongly negative correlation with annual precipitation $(\mathrm{r}=-0.63, \mathrm{p}=0.001$; Figure $5 \mathrm{~d}$; Table 4). This suggests that the tree died after 1980 and remained standing dead until the sampling in 1987.

Significant negative correlations between mean, minimum and maximum measured $\delta^{13} \mathrm{C}$ for the 21 tree individuals and the mean annual rainfall of the study sites were found. The least negative measured values (MAX) showed the strongest correlation with mean annual rainfall at the site with $\mathrm{r}=-0.51, \mathrm{p}=0.018$ (Fig. 6; MEAN: $\mathrm{r}=-0.48, \mathrm{p}=0.029$ and MIN: $\mathrm{r}=-0.45, \mathrm{p}=0.042$; excluding the dead sampled $T$. quintalata improves the correlations of all values (MAX: $r=-0.56, p=0.011$; MEAN: $r=-0.59, p=0.006$ and MIN: $r=-0.62, p=$ $0.003)$.

Table 4 Correlation results for stable carbon isotope time series of trees and annual rainfall time series. T. quintalata was a dead tree, all others were living trees

\begin{tabular}{ccc}
\hline $\mathbf{\delta 1 3 C}$ index & Rainfall Index & $\mathbf{r}$ \\
\hline C. odorata & Caparo, Venezuela & $\mathbf{- 0 . 5 9 ^ { \star * }}$ \\
\hline T. guyanensis & Caparo, Venezuela & -0.08 \\
\hline T. amazonia & Dorado-Tumeremo, Venezuela & $\mathbf{- 0 . 5 5 ^ { \star * }}$ \\
\hline T. superba & Biakoa, Cameroon & $\mathbf{- 0 . 4 4 ^ { * }}$ \\
\hline T. quintalata & Uriman, Venezuela & $\mathbf{- 0 . 6 3 ^ { \star * }}$ \\
\hline${ }^{*} \mathrm{p}<0.05 ;{ }^{* *} \mathrm{p}<0.01$ & & \\
\hline
\end{tabular}




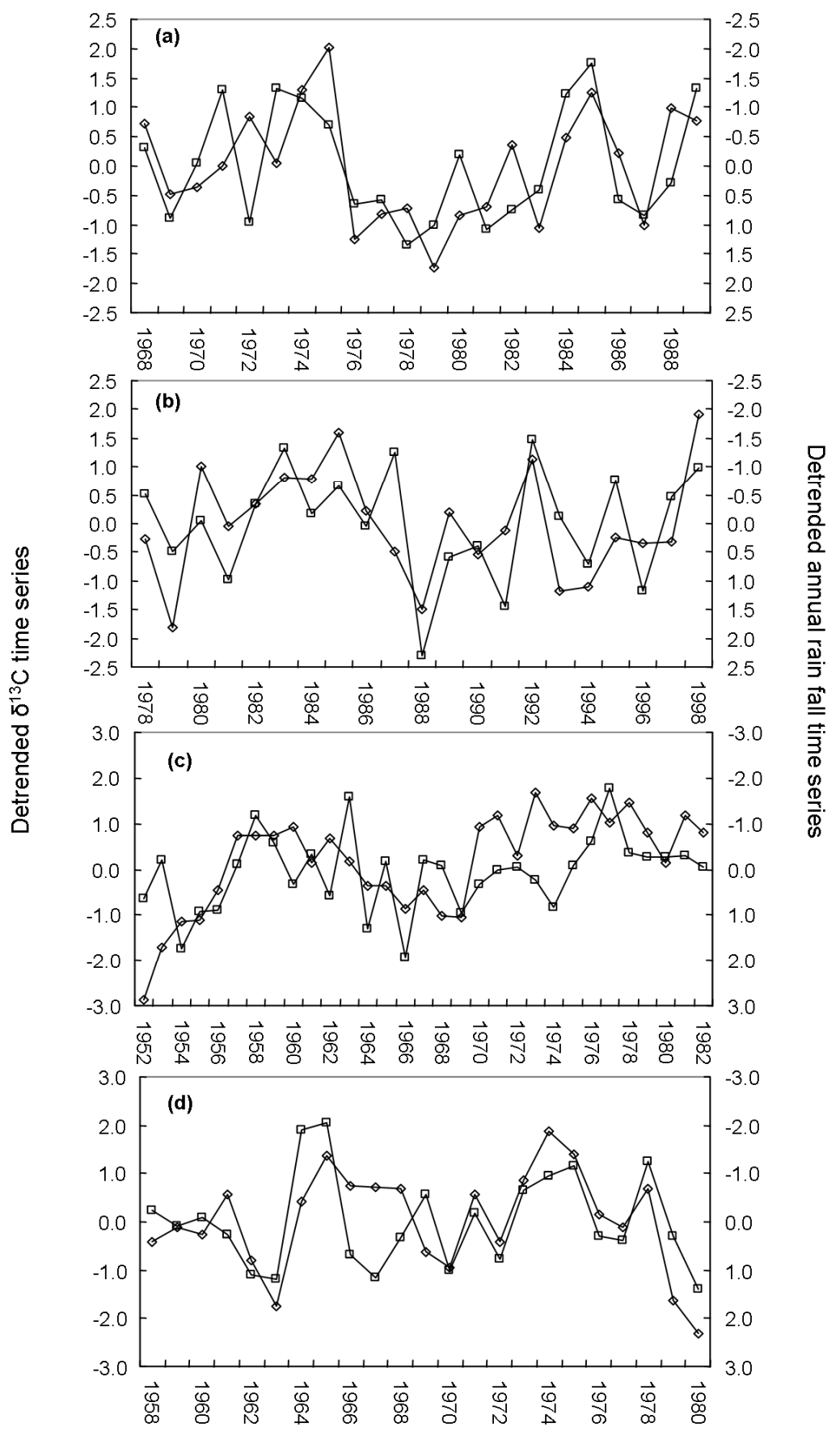

Fig 5 Detrended inter-annual $\delta^{13} \mathrm{C}$ profiles (diamonds) and detrended annual rainfall time series (squares) of (a) C. odorata from Caparo, Venezuela, (b) T. amazonia from Dorado-Tumeremo, Venezuela, (c) T. superba from Biakoa, Cameroon, and (d), T. quintalata from Uriman, Venezuela. Note the inverse axis for detrended rainfall series 


\section{DISCUSSION}

The analysis of growth responses of trees to climatic changes and variation is a challenge to environmental research in the discussion on global change. Many attempts have been undertaken to investigate adaptations of trees to drought stress, e.g. with photosynthesis and transpiration measurements (Borchert 1994; Cunningham 2005). Another promising tool is the interpretation of tree-ring time series. Substantial progress in understanding tree growth based on tree rings was made in recent decades (Schweingruber 1996). A major focus of those investigations was tree-ring width measurements, which show strong climatic responses and allow the development of paleoclimatic reconstructions (e.g. Esper et al. 2002). The analysis of stable carbon isotope ratios in tree rings is a more recent approach that has primarily been applied on trees from temperate zones (Danis et al. 2006; Gagen et al. 2006). In our study we compared trees from different hydrological sites to define how rainfall variations are influencing ${ }^{13} \mathrm{C}$ fractionation in tropical trees to enable a better interpretation of stable isotope patterns in the wood. At high resolution we found a similar intra-annual pattern that is described for trees from temperate zones (Helle and Schleser 2004) as well as for mangrove trees from Kenya, Africa (Verheyden et al. 2004b). In all cases, lowest (most negative) $\delta^{13} \mathrm{C}$ values were found at the ring boundaries. During the vegetation period values increase following varying trends from one year to the other, but all decrease towards the end with the exception of the very last ring (1989, cf. Figure 2) where there is an increase at the very end. Because this intra-annual behavior is observed under contrasting environmental site conditions it must be traced back to internal physiological processes. Towards the end of a vegetation period, starch is stored in wood tissue as Dünisch and Puls (2003) showed for Amazonian Cedrela odorata trees. Starch, which is enriched in ${ }^{13} \mathrm{C}$, is remobilized at the beginning of the growing period for the formation of new wood tissue. This leads to an increase of ${ }^{13} \mathrm{C}$ in the wood during this time, while later in the growing period enriched leaf carbon is used for wood formation (Helle and Schleser, 2004). Towards the end of the vegetation period, an isotope partitioning between enriched starch and depleted cell-wall tissue leads to the observed decrease of ${ }^{13} \mathrm{C}$ in our high-resolution pattern at the ring boundaries (Helle and Schleser 2004). The observed increase in the youngest ring near the bark may be traced back to the fact that starch is mainly stored in this part of the ring. For our medium-scale analyses the part of the growth zone very close to the boundaries could not be separated for sampling, because the core hole with $0.8 \mathrm{~mm}$ diameter produces a composite sample that cannot distinguish the wood immediately adjacent to the ring boundary. Thus, 
future intra-annual analysis may need to take this into consideration depending on the resolution of sub-sampling.

As mentioned above, the $\delta^{13} \mathrm{C}$ in the central parts of the tree rings show varying levels from year to year leading to the conclusion, that these follow external growth-influencing factors. As an example the years 1983 and 1987 were comparably wet in the Western-Llanos in Venezuela and the discrimination against ${ }^{13} \mathrm{C}$ in the wood of Cedrela odorata (Figure 2) was much higher than in the dry years 1984 and 1985. This supports the dominant influence of precipitation and water availability on $\delta^{13} \mathrm{C}$ over much of the period of ring formation.

We found some clear hints that $\delta^{13} \mathrm{C}$ varies considerably with the development of a tree, as many rain forest trees showed a significant lower $\delta^{13} \mathrm{C}$ value in the earliest ring of the stem than in all outermost samples. This is caused by so-called "juvenile effect". It reflects the potentially more ${ }^{13} \mathrm{C}$-depleted, respired soil $\mathrm{CO}_{2}$ that is a photosynthetic source for individuals growing close to the forest floor (Schleser and Jayasekera 1985). In addition, photosynthesis rates decrease because of the limited light conditions within closed forest stands and result in lower (more negative) $\delta^{13} \mathrm{C}$ values. This seems to be true for the tree individuals, growing in the understorey of closed forests during their juvenile stage. In contrast to that, the highresolution profile of $C$. odorata showed less negative $\delta^{13} \mathrm{C}$ values towards a young cambial age (youth) of the tree. Similarly the younger sample (Terse 43) from T. sericea from Katima Mulilo, Namibia, showed higher values than the older individual (Terse 34). An explanation could be extreme drought stress during their juvenile phase as these two individuals grew in open stands or rather in a plantation and had to face full radiation while having a shallow rooting system.

In the present study, all $\delta^{13} \mathrm{C}$ time series of tree individuals of the same species from the same sites, show significant correlations, indicating a common external factor that triggers stable-carbon isotope discrimination. Comparing different species from the same site or the same species from different sites, no consistent results were achieved. The variability in different species may depend to a large extend on species-specific properties, e.g., varying rooting depth or leaf anatomy, resulting in distinction of the species`sensitivity to climatic conditions at the same site. S. macrophylla, which did not show a distinct climate signal, is reported to have a minimum rooting depth of $150 \mathrm{~cm}$. In contrast $C$. odorata with rooting depth of $50 \mathrm{~cm}$ (USDA, NRCS, 2007) showed a higher sensitivity to rainfall, because the upper soil layers are more directly affected by rainfall variations. Borchert et al. (2002) report deep rooting trees in tropical forests in Costa Rica to be less affected or unaffected by seasonal drought events. 
To some extent a common signal is visible in the three $T$. amazonia trees from different sites. The annual precipitation time series of these three sites are significantly correlated and show high GLK values (La Selva, Costa Rica vs. Dorado-Tumeremo, Venezuela: $\mathrm{r}=0.422 *$, GLK $83 \% * *$ / La Selva, Costa Rica vs. km98 Sierra de Lema, Venezuela: $\mathrm{r}=0.465^{*}$, GLK $76 \% * *$ / Dorado-Tumeremo, Venezuela vs. km98 Sierra de Lema, Venezuela: $\mathrm{r}=0.786^{* *}$, GLK $84 \% \%^{* *}$ ), indicating, that these regions, although climatically different in the mean amount of rainfall, are subject to similar inter-annual variations in the periodicity and the absolute annual precipitation. Considering the similarities in $T$. amazonia samples that were collected at great distances from one another but which are influenced by analogous climatic variations, there is potential to study large-scale precipitation variations by analyzing tree rings of widely distributed individuals of the same species in areas where climatic parameters are strongly affected by hemispheric-scale circulation patterns (e.g. El Niño Southern Oscillation).

The correlation between precipitation time series and tree-ring isotopic data was significantly negative. The significant correlations found were evenly strong and independent of the humidity differences of the sites or the phenology of the trees. Growth-limiting factors are typically reported as being responsible for the isotopic fractionation in plants (Robertson et al. 2006). The relationship between precipitation and stable-carbon isotope time series can be interpreted in this context. Where moisture availability is limiting, stomatal conductance dominates the carbon fractionation. McCarroll and Loader (2004) therefore concluded that the dominant control in trees that are rarely subject to drought stress, may be photosynthetic rate, which is primarily controlled by irradiance and temperature. Intra-annual temperature variations are small in the inner tropics and only changes in irradiance related to varying cloudiness could have a strong influence on photosynthetic rates. The significant correlation of $\delta^{13} \mathrm{C}$ in $T$. quintalata with precipitation from the perhumid site Uriman, Venezuela (Figure 5d), however, shows that moisture availability can be a limiting factor for tree growth, even under prevailing moist conditions. Trees at perhumid sites appear to be sensitive even to slight variations in precipitation. Studies at La Selva, Costa Rica, have shown that short rainless periods (10 to 21 days) during the drier months (Jan-Apr) every year lead to a brief but marked drop in soil moisture content (Schwendenmann et al. 2003), causing a strong periodicity of tree phenology (Frankie et al. 1974) and tree growth (Fichtler et al. 2003). In addition, Cunningham (2004) reported a higher stomatal sensitivity to vapor pressure deficit in tropical rainforest species than in temperate rainforest species. The generally negative correlation between $\delta^{13} \mathrm{C}$ in the wood tissue and rainfall is moreover affirmed by the negative 
correlation between $\delta^{13} \mathrm{C}$ values for tree individuals and the general hydrological condition at the growing site found in this study (c.f. Figure 6).

The successful crossdating of the T. quintalata $\delta^{13} \mathrm{C}$ time series highlights the potential of carbon isotope measurements for tropical tree-ring analytical studies. As in many other tropical species, conventional tree-ring analysis methods may fail in this particular species because of the ambiguous tree-ring boundaries (Figure 1g).

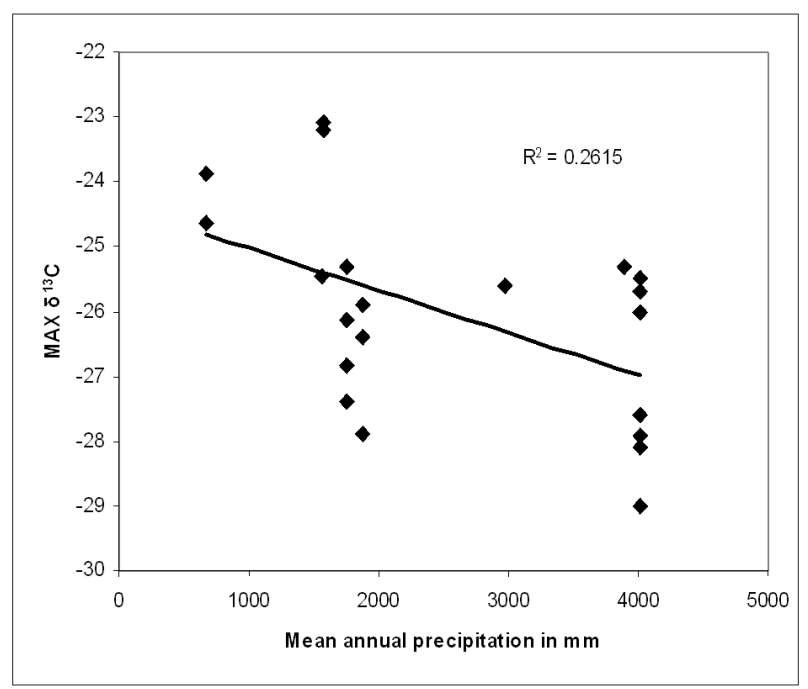

Fig 6 Trend of maximum annual $\delta^{13} \mathrm{C}(\%$ ) in relation to mean annual rainfall in $\mathrm{mm}$ of the sites. Plotted data include corrected $\delta^{13} \mathrm{C}$ values from radiocarbon studies listed in Table $1 b$

The results of this study show that tropical trees, like temperate trees, are recording carbon isotopic signals in the wood, which can be linked to common external factors. The analyses of tree-ring isotopic data in tropical trees with an annual resolution must be expanded in sample size and length to gain more insights into the particular factors influencing carbon isotope fractionation processes in tropical trees. A combination of several factors controls $\delta^{13} \mathrm{C}$ variability under most conditions (Leavitt 2002), requiring further investigations to focus on the relative influence of various factors on growth conditions and carbon isotope fractionation in tropical trees. Factors such as stand position and competition pressure, associated with distinctions in light and water availability, should be considered when selecting trees, to achieve a more homogeneous sample set. Future isotopic investigations on tropical tree rings could provide valuable tools for paleoclimatic studies in tropical regions. 


\section{ACKNOWLEDGEMENTS}

E. Fichtler was sponsored by the Scholarship Programme of the German Federal Environmental Foundation (DBU). We are grateful for the precipitation data provided by Sharon E. Nicholson and thank Valerie Trouet for linguistic help and useful comments on an earlier version of the manuscript. Finally we thank two anonymous reviewers and the Editor for their valuable comments and suggestions. 


\section{REFERENCES}

Borchert, R., 1994. Water status and development of tropical trees during seasonal drought. Trees - Structure and Function 8:115-125.

Borchert, R., G. Rivera, and W. Hagnauer, 2002. Modification of vegetative phenology in a tropical semi-deciduous forest by abnormal drought and rain. Biotropica 34:27-39.

Borella, S., M. Leuenberger, M. Saurer, and R. Siegwolf, 1998. Reducing uncertainties in $\delta^{13} \mathrm{C}$ analysis of tree rings: Pooling, milling, and cellulose extraction. Journal of Geophysical Research - Atmospheres 103:19519-19526.

Brienen, R. J. W., Zuidema, P.A., 2005. Relating tree growth to rainfall in Bolivian rain forests: A test for six species using tree-ring analysis. Oecologia 146, 1-12.

Brienen, R. J. W., Zuidema, P.A., 2006. The use of tree rings in tropical forest management. Projecting timber yields of four Bolivian tree species. Forest Ecology and Management 226:256-267.

Callado, C. H., S. J. D. Neto, F. R. Scarano, and C. G. Costa, 2001. Periodicity of growth rings in some flood-prone trees of the Atlantic Rain Forest in Rio de Janeiro, Brazil. Trees - Structure and Function 15:492-497.

Cunningham, S. C., 2004. Stomatal sensitivity to vapour pressure deficit of temperate and tropical evergreen rainforest trees of Australia. Trees - Structure and Function 18:399407.

Cunningham, S. C., 2005. Photosynthetic responses to vapour pressure deficit in temperate and tropical evergreen rainforest trees of Australia. Oecologia 142:521-528.

Danis, P. A., V. Masson-Delmotte, M. Stievenard, M. T. Guillemim, V. Daux, P. Naveau, and U. von Grafenstein, 2006. Reconstruction of past precipitation $\delta^{18} \mathrm{O}$ using tree-ring cellulose $\delta^{18} \mathrm{O}$ and $\delta^{13} \mathrm{C}$ : A calibration study near Lac d'Annecy, France. Earth and Planetary Science Letters 243:439-448.

Dünisch, O., and J. Puls, 2003. Changes in content of reserve materials in an evergreen, a semi-deciduous, and a deciduous Meliaceae species from the Amazon. Journal of Applied Botany 77:10-16.

Ehleringer, J. R., and T. A. Cooper, 1988. Correlations between carbon isotope ratio and microhabitat in desert plants. Oecologia 76:562-566.

Ehleringer, J. R., C. B. Field, Z. F. Lin, and C. Y. Kuo, 1986. Leaf carbon isotope and mineral-composition in subtropical plants along an irradiance cline. Oecologia 70:520526. 
Esper, J., E. R. Cook, and F. H. Schweingruber, 2002. Low-frequency signals in long treering chronologies for reconstructing past temperature variability. Science 295:22502253.

Farquhar, G. D., J. R. Ehleringer, and K. T. Hubick, 1989. Carbon isotope discrimination and photosynthesis. Annual Review of Plant Physiology and Plant Molecular Biology 40:503-537.

Fichtler, E., D. A. Clark, and M. Worbes, 2003. Age and long-term growth of trees in an oldgrowth tropical rain forest, based on analyses of tree rings and C-14. Biotropica 35:306-317.

Fichtler, E., V. Trouet, H. Beeckman, P. Coppin, and M. Worbes, 2004. Climatic signals in tree rings of Burkea africana and Pterocarpus angolensis from semiarid forests in Namibia. Trees - Structure and Function 18:442-451.

Frankie, G.W., H. G. Bake, and P. A. Opler, 1974. Comparative phenological studies of trees in tropical wet and dry forests in lowlands of Costa Rica. Journal of Ecology 62:881919.

Gagen, M., D. McCarroll, and J. L. Edouard, 2006. Combining ring width, density and stable carbon isotope proxies to enhance the climatic signal in tree rings: An example from the southern French Alps. Climatic Change 78:363-379.

Gebrekirstos, A., M. Worbes, D. Teketay, M. Fetene, and R. Mitlöhner, 2009. Stable carbon isotopes ratios in tree rings of co-occurring species from semi-arid tropics in Africa: Patterns and climatic signals. Global and Planetary Change 66:253-260.

Gourlay, I. D., 1995. Growth ring characteristics of some African Acacia species. Journal of Tropical Ecology 11:121-140.

Harlow, B. A., J. D. Marshall, and A. P. Robinson, 2006. A multi-species comparison of $\delta^{13} \mathrm{C}$ from whole wood, extractive-free wood and holocellulose. Tree Physiology 26:767774.

Helle, G., and G. H. Schleser, 2004. Beyond $\mathrm{CO}_{2}$-fixation by Rubisco - an interpretation of ${ }^{13} \mathrm{C} /{ }^{12} \mathrm{C}$ variations in tree rings from novel intra-seasonal studies on broad-leaf trees. Plant, Cell and Environment 27, 367-380.

Hietz, P., W. Wanek, and O. Dünisch, 2005. Long-term trends in cellulose $\delta^{13} \mathrm{C}$ and water-use efficiency of tropical Cedrela and Swietenia from Brazil. Tree Physiology 25:745-752. 
Kaennel, M., and F. H. Schweingruber, 1995. Multilingual Glossary of Dendrochronology. Terms and definitions in English, German, French, Spanish, Italian, Portuguese and Russian. Birmensdorf, Swiss Federal Institute for Forest, Snow and Landscape Research. Berne Stuttgart, Vienna, Haupt.

Leavitt, S. W., 2002. Prospects for reconstruction of seasonal environment from tree-ring $\delta^{13} \mathrm{C}$ : Baseline findings from the Great Lakes area, USA. Chemical Geology 192:4758.

Leavitt, S. W., and A. Long, 1989. Drought indicated in C-13/C-12 ratios of southwestern tree rings. Water Resources Bulletin 25:341-347.

Leavitt, S. W., and A. Long, 1991. Seasonal stable-carbon isotope variability in tree rings possible paleoenvironmental signals. Chemical Geology 87:59-70.

Livingston, N. J., R. D. Guy, Z. J. Sun, and G. J. Ethier, 1999. The effects of nitrogen stress on the stable carbon isotope composition, productivity and water use efficiency of white spruce (Picea glauca (Moench) Voss) seedlings. Plant Cell and Environment 22:281-289.

Loader, N. J., I. Robertson, and D. McCarroll, 2003. Comparison of stable carbon isotope ratios in the whole wood, cellulose and lignin of oak tree-rings. Palaeogeoraphy Palaeoclimatology Palaeoecology 196:395-407.

McCarroll, D., and N. J. Loader, 2004. Stable isotopes in tree rings. Quaternary Science Reviews 23:771-801.

Menezes, M., U. Berger, and M. Worbes, 2003. Annual growth rings and long term growth patterns of mangrove trees from the Braganca Peninsula, Northern Brazil. Wetlands Ecology and Management 11:233-242.

Oldenborgh, G. J. van, and G. Burgers, 2005. Searching for decadal variations in ENSO precipitation teleconnections. Geophysical Research Letters 32: L15701, doi:10.1029/2005GL023110.

Ortiz, J., L. Hernandez, and M. Worbes, 2006. Crecimiento radial de Tachigali y Terminalia en bosque de tierra baja al sureste de Venezuela. Acta Botanica Venezuelica 29:211234.

OTS, 2007. Http://www.ots.duke.edu/en/laselva/metereological.shtml, metereological data. Organization for Tropical Studies, 90630 Durham, USA.

Robertson, I., N. J. Loader, C. A. Froyd, N. Zambatis, I. Whyte, and S. Woodborne, 2006. The potential of the baobab (Adansonia digitata L.) as a proxy climate archive. Applied Geochemistry 21:1674-1680. 
Schleser, G. H., and R. Jayasekera, 1985. $\delta^{13} \mathrm{C}$ variations of leaves in forests as an indication of reassimilated $\mathrm{CO}_{2}$ from the soil. Oecologia 65:536-542.

Schöngart, J., W. J. Junk, M. T. F. Piedade, J. M. Ayres, A. Hüttermann, and M. Worbes, 2004. Teleconnection between tree growth in the Amazonian floodplains and the El Nino-Southern Oscillation effect. Global Change Biology 10:683-692.

Schöngart, J., B. Orthmann, K. J. Hennenberg, S. Porembski, and M. Worbes, 2006. Climategrowth relationships of tropical tree species in West Africa and their potential for climate reconstruction. Global Change Biology 12:1139-1150.

Schweingruber, F. H., 1996. Tree Rings and Environment. Dendroecology. Birmensdorf, Swiss Federal Institute for Forest, Snow and Landscape Research. Berne Stuttgart, Vienna, Haupt: 609pp.

Schwendenmann, L., E. Veldkamp, T. Brenes, J. J. O'Brien, and J. Mackensen, 2003. Spatial and temporal variation in soil $\mathrm{CO}_{2}$ efflux in an old-growth neotropical rain forest, $\mathrm{La}$ Selva, Costa Rica. Biogeochemistry 64:111-128.

Stahle, D. W., P. T. Mushove, M. K Cleaveland, F. Roig, and G. A. Haynes, 1999. Management implications of annual growth rings in Pterocarpus angolensis from Zimbabwe. Forest Ecology and Management 124:217-229.

Tarhule, A., and S. W. Leavitt, 2004. Comparison of stable-carbon isotope compostion in the growth rings of Isoberlinia doka, Daniella oliveri, and Tamarindus indica and West African climate. Dendrochronologia 22:61-70.

Trouet, V., P. Coppin, and H. Beeckman, 2006. Annual growth ring patterns in Brachystegia spiciformis reveal influence of precipitation on tree growth. Biotropica 38:375-382.

USDA, NRCS, 2007. The PLANTS Database, http://plants.usda.gov. National Plant Data Center, Baton Rouge, LA 70874-4490 USA.

Van de Water, P. K., 2002. The effect of chemical processing on the $\delta^{13} \mathrm{C}$ value of plant tissue. Geochimica et Cosmochimica Acta 66:1211-1219.

Verheyden, A., J. G. Kairo, H. Beeckman, and N. Koedam, 2004a. Growth rings, growth ring formation and age determination in the mangrove Rhizophora mucronata. Annals of Botany 94:59-66.

Verheyden, A., G. Helle, G. H. Schleser, F. Dehairs, H. Beeckman, and N. Koedam, 2004b. Annual cyclicity in high-resolution stable carbon and oxygen isotope ratios in the wood of the mangrove tree Rhizophora mucronata. Plant Cell and Environment 27:1525-1536.

Walter, H., and H. Lieth, 1969. Klimadiagramm-Weltatlas. Gustav Fischer Verlag, Jena 1967. 
Worbes, M., 1999a. Degradacion e historia de la Vegetacion boscosa de la Gran Sabana. In: Ecologia de la Altiplanicie de la Gran Sabana, edited by L. Hernandez, pp. 84-107. Koeltz Scientific Books, Germany.

Worbes, M., 1999b. Annual growth rings, rainfall-dependent growth and long-term growth patterns of tropical trees from the Caparo Forest Reserve in Venezuela. Journal of Ecology 87:391-403.

Worbes, M., 2002. One hundred years of tree-ring research in the tropics- a brief history and an outlook to future challenges. Dendrochronologia 20:217-231.

Worbes, M., R. Staschel, A. Roloff, and W. J. Junk, 2003. Tree-ring analysis reveals age structure, dynamics and wood production of a natural forest stand in Cameroon. Forest Ecology and Management 173:105-123. 


\title{
5 WOOD ANATOMICAL VARIABLES IN TROPICAL TREES AND THEIR RELATION TO SITE CONDITIONS AND INDIVIDUAL TREE MORPHOLOGY
}

ESTHER FICHTLER \& MARTIN WORBES

PUBLISHED IN:

IAWA JouRnAL 2012, Volume 33 (2012), Number 2, Pages 119-140

\begin{abstract}
For a deeper understanding of the influence of external growth factors on the wood structure, samples of 139 tropical trees were analysed across plant families and a wide climatic gradient. For all samples a unique data set on climate, site and forest stand conditions on is available. Different vessel variables as well as the relative cross-sectional area of vessel, parenchyma and fibre tissue were studied in individual tree rings of varying sizes. High within-species and within-site variation of wood anatomical variables was observed which was higher than inter-species and -site variation. In addition, between-ring variation within many individuals was higher than variation between individuals. The differences within individuals show how trees can adapt or adjust to environmental variability and can provide information about the plasticity of a species under changing environmental conditions.

The variable 'vessel diameter' showed the strongest and most significant correlations to other wood anatomical variables, but also to climate parameters and tree morphology. Thereby tree size (DBH \& height) and crown exposure to light had the strongest impact on vessel size and consequently on hydraulic stem architecture. General climate conditions only showed a weak influence on vessel variables. The principal component analyses revealed a strong influence of tree morphology and a weaker influence of climate on the hydraulic stem architecture. In contrast the general climatic site conditions strongly influenced fibre and parenchyma tissue.
\end{abstract}




\section{INTRODUCTION}

The amount and structure of wood determine the attributes of a tree's stem like biomechanical support, velocity of water and nutrient transport as well as storage capacity for water, nutrients and chemical compounds such as carbohydrates and lipids (Chave et al. 2009). Demands of the plant can shift through time depending on ontogenetic stage of the tree (Poorter \& Kitajima 2007) but also depending on changes in the regional or local environment (Wimmer 2002). As a result the variation in number, size, form, and arrangement of cell types leads to a high diversity of wood structures that perform different function across a huge range of ecological settings (Chave et al. 2009). This does not only hold for the species level, but also at an individual tree-level (e.g. Plomion et al. 2001).

Functional traits of species influence their survival, growth and reproductive capacity (Ackerly 2003). Studying functional characteristics has contributed much to the understanding of ecosystem structure and functioning and their responses to environmental influences (Baraloto et al. 2010). Plant growth and survival depend on the interplay of coordinated stem, leaf, and root features (Reich et al. 2003; Cavender-Bares et al. 2004) and many studies focused on leaf-phenological characteristics as indicators of adaptation to various environments (e.g. Wright et al. 2010). Less attention has been paid to spatial or temporal variation in the 'harder-to-measure' wood anatomical variables of different species. Water transport capacity and safety, besides linked to the structure of bordered pit membranes (Wheeler et al. 2005; Choat et al. 2008), is mainly defined by vessel size, vessel frequency as well as vessel arrangement and play a key role for tree growth especially in environments where water availability is determining tree growth (Tyree \& Zimmermann 2002). Longdistance water transport in trees occurs passively through the lumina of non-living conductive cells in the xylem (Carlquist 1975), therefore vessel diameter and vessel frequency are most likely to influence the efficiency and pathway of water movement. Besides efficiency, safety of the conducting system is important for tree growth and survival. Larger conduits are more vulnerable to cavitation than smaller ones (Sperry 2003). In addition, the vulnerability to cavitation depends on the mechanical strength of the conduits and their surrounding cells: compared to species with low wood density plants with greater wood density can tolerate a higher negative pressure before the hydraulic conductivity is affected negatively (Hacke et al. 2001). 
The general concept of tree ring studies is that ring width is a predictor of tree performance (Schweingruber 1996) in a changing environment. Basically, a tree ring is a record of tree survival (Smith 2008), with the tree reacting as a filter (Fritts 1976): changes in environmental conditions are transformed into physiological and metabolic reactions resulting in tree rings with different width. To respond and to mitigate changing environmental conditions trees react with dynamic wood formation processes through adjustments of wood anatomical variables (Wimmer 2002), e.g. differing vessel size and vessel number in different tree rings. This implies that these variables potentially encode ecological information within single rings (e.g. Sass \& Eckstein 1995; Garcia Gonzales \& Eckstein 2003), a fact that is used in dendrochronological studies on temperate trees to reconstruct past environmental conditions with sub-annual resolution (Fonti et al. 2010). A successive number of studies has focussed on the fundamental relation between different vessel variables and their function and importance for ecological strategy in temperate and tropical trees (e.g. Lopez et al. 2005; Preston et al. 2006; Sperry et al. 2006; Rana et al. 2009; McCulloh et al. 2010). Other studies investigated species-specific differences in vessel variables in relation to precipitation or aridity (Choat et al. 2007; Martinez-Cabrera et al. 2009; Bosio et al. 2010). In addition wood density has become increasingly important in studies on life history strategy in trees from the tropics (Müller-Landau 2004). A recent study focussed on the inter-species variation of anatomical attributes within a tropical stand (Poorter et al. 2010). In this study a high interspecies variation of anatomical characteristics was observed, that was related to general species-specific juvenile growth and survival rates. However, little is known on the interplay of species-specific, environmental and tree morphological factors that influence wood anatomical variables in tropical trees. Therefore the present study is intended as a pilot to reveal information on the relation between site-specific, family-specific and individual within-a-tree variation in various wood anatomical variables for trees from different phylogenetic groups and from climatically different sites. We applied a straightforward approach on single trees under consideration of their individual growth rates, their size and age as well as their exposition to light. Finally we related wood anatomical variables to the general climatic site conditions. To study the individual plasticity of wood anatomical characteristics within single trees we performed our analysis on individual tree rings of known age. 


\section{MATERIALS AND METHODS}

The sample set of this study consisted of 139 stem discs from 35 angiosperm families, including 83 genera and 111 species. All samples originated from the tropical stem-disc collection of the Department of Crop Sciences, Agronomy in the Tropics, University of Göttingen, Germany, and have been subject to earlier tree ring studies (e.g. Worbes 1985, 1989, 1999 a, b; Worbes et al. 1992; Dezzeo et al. 2003; Fichtler et al. 2003, 2004; Raschke 2003; Ortiz et al. 2006). The discs have been collected from trees growing at 14 forest sites representing various tropical climates in Africa and South America (Table 1). Within this stem disc collection the samples were selected randomly. This selection compromises tree individuals from diverse forest strata and with a wide range of stem and crown dimensions. They represent different species with a large variety in wood anatomy including distinct and indistinct ring structures. For the majority of samples individual information on stem diameter, tree height and crown exposure to light at the time of felling as well as growth rates and wood density was available.

Table 1. Information on mean annual rainfall and the mean duration of the stress period (= unfavourable growth conditions for trees) of the study sites. * The sites are located in floodplains, where the stress period equals the length of inundation. At all other sites it is the duration of the dry season.

\begin{tabular}{llll}
\hline Site & Country & $\begin{array}{l}\text { Mean annual } \\
\text { rainfall } \\
\text { mm }\end{array}$ & $\begin{array}{l}\text { Average } \\
\text { in }\end{array}$ \\
& & $\begin{array}{l}\text { duration } \\
\text { stress } \\
\text { in weeks }\end{array}$ period \\
\hline \hline Ondangwa & Namibia & 454 & 31 \\
Katima Mulilo & Namibia & 675 & 31 \\
Pantanal & Brazil & 1100 & 13 \\
Mapire* & Venezuela & 1333 & 23 \\
La Pacifica & Costa Rica & 1356 & 22 \\
Dorado-Tumeremo & Venezuela & 1560 & 10 \\
Biakoa & Cameroon & 1570 & 12 \\
Caparo & Venezuela & 1750 & 13 \\
Gran Sabana & Venezuela & 1880 & 10 \\
Igapó* & Brazil & 2100 & 27 \\
Várzea* & Brazil & 2100 & 27 \\
Km 98 Sierra de Lema & Venezuela & 2975 & 7 \\
Uriman & Venezuela & 3890 & 6 \\
La Selva & Costa Rica & 4230 & 2 \\
\hline \hline
\end{tabular}


The climate types at the sample sites cover a wide range along a gradient in mean annual rainfall. The most humid site is La Selva, Costa Rica, with more than $4000 \mathrm{~mm}$ rainfall per year and a short dry season of about two weeks on average. The driest site is Ondangwa, Namibia, with less than $500 \mathrm{~mm}$ rainfall per year and a dry period of up to seven months (Table 1). In addition we included sites which are periodically exposed to a surplus of water and consequently inundated for a certain time. These are floodplains from the Amazon and the Orinoco as well as the Rio Negro. The effect of the flooding on the physiology of trees is comparable to a drought period at never flooded sites and can be defined as a stress period (Worbes 1997). For the other sites the mean annual precipitation was considered as the key climate variable. For the comparison of both principal forest types we included the length of the stress period reflecting the intensity of unfavourable growth conditions which can be related to either dry conditions or to flooding. The climate data were retrieved from various sources used in earlier studies (Worbes 1985, 1989, 1999 a,b; Worbes et al. 1992; Staschel et al. 1996; Dezzeo et al. 2003; Fichtler et al. 2003, 2004; Raschke 2003; Ortiz et al. 2006).

The wood discs were polished with a belt sander using sanding bands with grit up to 600 and wood surfaces were cleaned from dust with compressed air. On each stem disc three mature growth rings were selected. To cover a large variation in terms of ring width for each tree individual, the rings represented a narrow, a medium, and a wide growth ring considering the range of ring width on each individual stem disc. Digital photographs were taken with Leica Application Suite 3.6.0 and a digital camera (Leica DFC 290, Germany) mounted on a stereo-microscope (Wild M3Z, Switzerland); magnification ranged from 6.5x-40x depending on the ring size. Photographs were taken with maximum magnification to show at least two ring boundaries to ensure the analysis of a complete ring width. For each picture an individual measuring frame was set with maximum tangential width in relation to a radial width adapted to the tree-ring width. Vessels within this frame were manually colour-coded using the freeware GIMP 2.6.5 (www.gimp.org). Digital calibration and measurements of the vessel variables and cross-sectional area of three different tissue components (vessel, fibre and parenchyma) were performed with the program AnalySIS (Soft Imaging Systems, Germany) on the basis of colour thresholds. Within the measuring frame, all individual lumen diameters (VD) of single vessels were measured: vessels are not circular and each individual vessel diameter was thus based on the average of 180 diameter measurements through the vessel centre in $1^{\circ}$ steps from $1^{\circ}$ to $179^{\circ}$. Furthermore individual vessel area (VA) and the distance to the nearest neighbouring vessel (DNN) from vessel edge to vessel edge were measured. Vessel frequency per $\mathrm{mm}^{2}(\mathrm{VF})$ and the cross-sectional area occupied by vessel (VCA), fiber 
(FCA) and parenchyma (PCA) were measured based on individual rings (in some species differences in PCA and FCA could not be measured on the base of colour thresholds, cf. valid $\mathrm{N}$ in the tables). In addition the ring width (RW) was determined and the ring age (RA) was counted on the disc. Results were transferred into EXCEL 2003 (Microsoft Corp., USA). Hydraulic properties including vulnerability index ( $\mathrm{VI}=\mathrm{VD} / \mathrm{VF})$, vessel composition index $(\mathrm{S}=\mathrm{VA} / \mathrm{VF})$, vessel lumen fraction $(\mathrm{F}=\mathrm{VA} * \mathrm{VF})$ and theoretical hydraulic conductivity $\left(\mathrm{K}_{\mathrm{t}}\right.$, see equation below), were calculated for each ring. VI and $S$ describe the vessel characteristics within the tree ring: high VI and $\mathrm{S}$ indicate that the conducting area is comprised of a few large vessels; low VI and S indicate the presence of many small vessels. F indicates the percentage area of the tree ring covered by water-conducting vessel lumina. $\mathrm{K}_{\mathrm{t}}$ is a measure for the efficiency of the water-transport system and is based on the HagenPoiseuille equation (Tyree \& Zimmermann 2002). In this comparative study, we used a simplified equation by including vessel frequency (VF) and average vessel diameter (VD):

$$
\mathrm{K}_{\mathrm{t}}=\left(\pi \rho_{\mathrm{w}} / 128 \eta\right) * \mathrm{VF} *(\mathrm{VD})^{4}
$$

in which $K_{t}$ is the theoretical hydraulic conductivity (in $\mathrm{kg} \mathrm{m}^{-1} \mathrm{MPa}^{-1} \mathrm{~s}^{-1}$ ), $\eta$ is the viscosity of water at $20^{\circ} \mathrm{C}\left(1.002 \times 10^{-3} \mathrm{~Pa} \mathrm{~s}\right.$ at $\left.20^{\circ} \mathrm{C}\right)$ in $\mathrm{Pa} \mathrm{s}, \rho_{\mathrm{w}}$ the density of water at $20^{\circ} \mathrm{C}$ $\left(998.2 \mathrm{~kg} \mathrm{~m}^{-3}\right.$ at $\left.20{ }^{\circ} \mathrm{C}\right)$. The theoretical hydraulic conductivity $\left(\mathrm{K}_{\mathrm{t}}\right)$ used here is always higher than the real conductivity because the resistance of the vessel end-walls (Sperry et al. $2005,2006)$ and cavitated vessels are disregarded. An overview on all parameters is given in Table 2.

Statistical analyses were performed in two steps. First, analyses were run with individual ring data. In the next step, mean values were calculated for each individual tree on the basis of the three ring categories (narrow, average, wide). Finally we added information on climatic site conditions and individual tree data on stem diameter (DBH), tree height (height) and crown exposure to light (CE) to the data set ( $c f$. Table 2; CE has the following values: 1 , tree does not receive any direct light; 2 , it receives lateral light; 3 , it partly receives overhead light; 4, it receives full overhead light; 5, it has an emergent crown).

Pearson's correlation analyses were used to explore relationships between woodanatomical variables, calculated hydraulic variables, tree morphological characteristics and climatic variables. Differences in wood anatomical attributes between families, sites and between morphological categories ( $\mathrm{DBH}$, height and $\mathrm{CE}$ ) were tested with an analysis of variance (ANOVA); post-hoc comparisons were conducted using Tukey's HSD test, when 
ANOVA results were significant. Finally, a principal component analysis was run to evaluate how wood traits were associated among each other and with tree morphology and macro climate. All statistical analyses were carried out using STATISTICA 9 (StatSoft, Inc., USA).

Table 2. Overview and explanation of the wood anatomical variables and parameters on individual tree performance included in this study.

\begin{tabular}{|c|c|c|}
\hline Parameter & unit & Description/Formula \\
\hline VD & $\mathrm{mm}$ & Vessel Diameter \\
\hline VA & $\mathrm{mm}^{2}$ & Vessel Area \\
\hline VF & $\mathrm{mm}^{2}$ & Vessel Frequency \\
\hline DNN & $\mathrm{mm}$ & Distance to Next Neighbour (edge to edge) \\
\hline VCA & $\%$ & Area occupied by Vessels \\
\hline FCA & $\%$ & Area occupied by Fibres \\
\hline PCA & $\%$ & Area occupied by Parenchyma \\
\hline VI & unitless & Vulnerability Index ( = Vessel Diameter / Vessel Frequency) \\
\hline $\mathbf{S}$ & $\mathrm{mm}^{4}$ & Vessel Composition Index (= Vessel Area / Vessel Frequency) \\
\hline $\mathbf{F}$ & unitless & Lumen Fraction (= Vessel Area * Vessel Frequency) \\
\hline $\mathbf{K}_{\mathbf{t}}$ & $\mathrm{kg} \mathrm{m}^{-1} \mathrm{MPa}^{-1} \mathrm{~s}^{-1}$ & Theoretical Hydraulic Conductivity \\
\hline RW & $\mathrm{mm}$ & Ring Width \\
\hline RA & years & Ring Age \\
\hline WD & $\mathrm{g} / \mathrm{cm}^{3}$ & Wood Specific Gravity \\
\hline DBH & unitless & Diameter Class $(1=5-15 \mathrm{~cm}$, going up in $10 \mathrm{~cm}$ steps $)$ \\
\hline Height & $\mathrm{cm}$ & Individual Tree Height \\
\hline CE & unitless & Crown Exposure $(1-5,1=$ totally in shade up to $5=$ full exposure $)$ \\
\hline PREC & $\mathrm{mm}$ & Mean Annual Precipitation \\
\hline STRESS & weeks & Length of 'Stress-Period' \\
\hline STRESS level & unitless & Classes for STRESS ( $1<10$ weeks up to $3>20$ weeks) \\
\hline
\end{tabular}

\section{RESULTS}

VARIATION IN VASCULAR DESIGN, TISSUE COMPOSITION, AND RING WIDTH The investigated samples covered all basic types of growth zone structures as described in Worbes (1989), as well as in Worbes \& Fichtler (2010): (A) several rows of fiber cells with reduced radial diameter and thickened walls result in density variations that mark the growth ring boundaries; (B) boundaries are formed by marginal parenchyma bands of one or more cells layers; (C) periodically recurring parenchyma and fiber bands of different widths result in a pattern delineating the boundary of the tree ring and (D) varying frequency and diameters of vessels appear in certain areas within one ring. 
The measured wood-anatomical structures, in particular the vascular design, varied substantially across the analysed individuals (Fig. 1, Table 3). Furthermore we could observe a high degree of variability within individual trees. Vessel size, frequency and distance to the next neighbouring vessel were measured in 40831 vessels from 417 rings in total. Between individual rings the average vessel diameter (VD) varied between $42 \mu \mathrm{m}$ and $352 \mu \mathrm{m}$, vessel frequency (VF) between $0.99 \mathrm{~mm}^{-2}$ and $191 \mathrm{~mm}^{-2}$. The variation of cross-sectional area occupied ranged for vessels (VCA) between $1.3 \%$ and $49.1 \%$, for fibres (FCA) between 18.8 $\%$ and $70.3 \%$ and for parenchyma (PCA) between $16.8 \%$ and $67.9 \%$. Within the complete sample set, ring widths (RW) varied between $0.14 \mathrm{~mm}$ and $19 \mathrm{~mm}$. An overview of the descriptive statistics for all measured values is given in Table 3.

Table 3. Descriptive statistics for measured and calculated wood anatomical variables of individual rings: vessel diameter (VD), vessel area (VA), vessel frequency (VF), distance to the next vessel neighbour (DNN), vessel cross-sectional area (VCA), fibre cross-sectional area (FCA), parenchyma cross-sectional area (PCA), vulnerability index (VI), vessel composition index (S), vessel lumen fraction $(\mathrm{F})$, theoretical hydraulic conductivity $\left(\mathrm{K}_{\mathrm{t}}\right)$, ring width $(\mathrm{RW})$ and ring age $(\mathrm{RA})$. Given are standard descriptive statistics: no. of cases (valid N), minimum, maximum, mean and standard deviation.

\begin{tabular}{llllll} 
& Valid N & MIN & MAX & MEAN & STD DEV \\
\hline \hline VD & 417 & 0.042 & 0.352 & 0.144 & 0.060 \\
VA & 417 & 0.00 & 0.09 & 0.02 & 0.02 \\
VF & 417 & 0.99 & 191.08 & 14.84 & 20.54 \\
DNN & 417 & 0.00 & 0.32 & 0.07 & 0.07 \\
VCA & 417 & 1.3 & 49.1 & 13.1 & 7.5 \\
FCA & 344 & 18.8 & 70.3 & 44.8 & 9.6 \\
PCA & 344 & 16.8 & 67.9 & 41.0 & 10.4 \\
VI & 417 & 0.00 & 0.31 & 0.03 & 0.05 \\
S & 417 & 0.00 & 0.08 & 0.01 & 0.01 \\
F & 417 & 0.01 & 0.49 & 0.13 & 0.07 \\
K & 417 & 4.5 & 1640.0 & 113.1 & 160.5 \\
RW & 417 & 0.14 & 18.85 & 3.01 & 2.55 \\
RA & 417 & 2 & 160 & 47 & 29 \\
\hline \hline
\end{tabular}



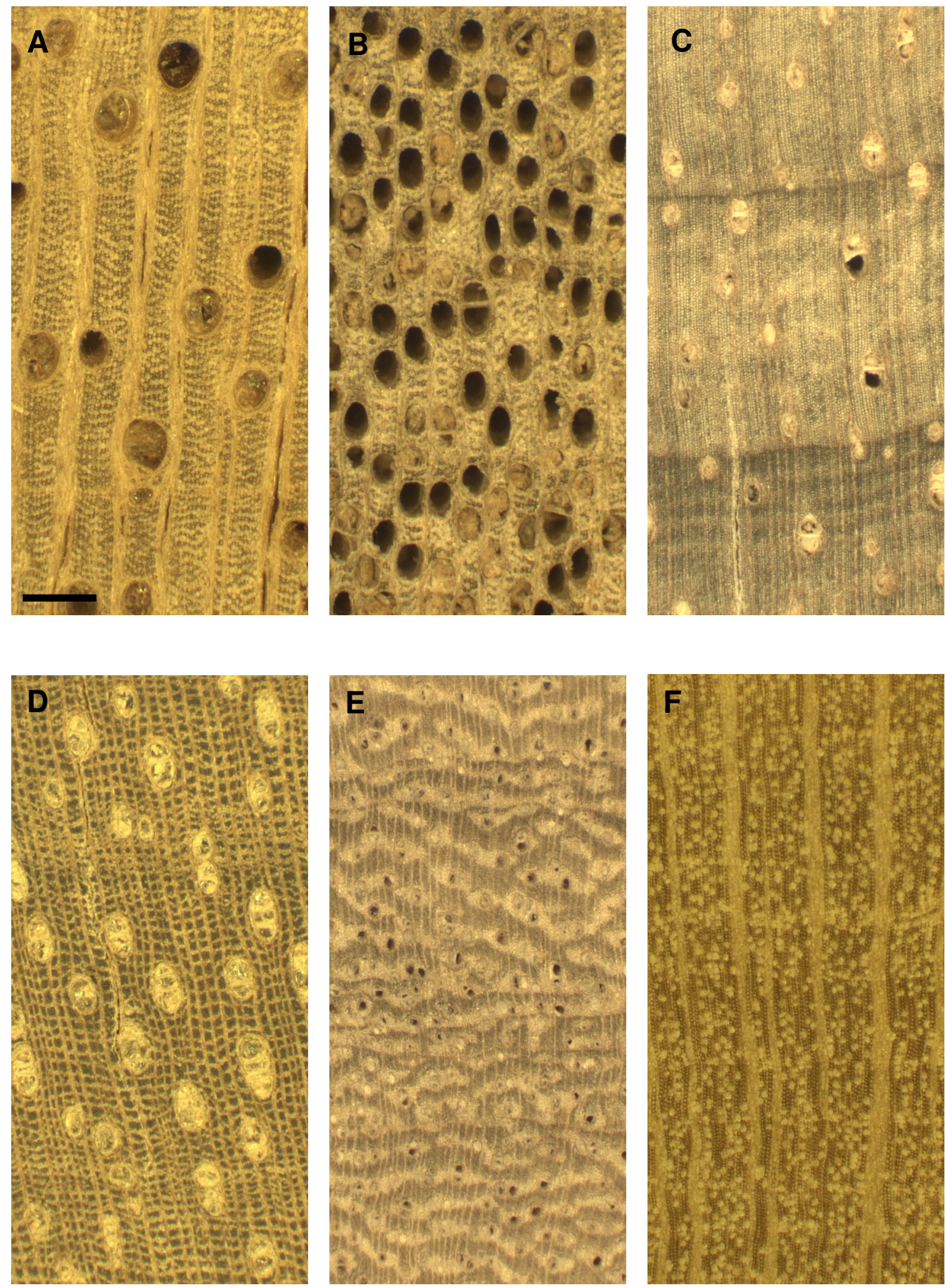

Figure 1 A-F. Differences of the vascular design in the cross sections of six tree individuals exhibiting diverse strategies in the water transport system regulated by the combination of vessel size and frequency. All pictures were taken with the same magnification to allow a direct visual comparison, scale bar below the pictures represents $2 \mathrm{~mm}$. (A) Ceiba pentandra from La Pacifica, (B) Pseudobombax munguba from Várzea, (C) Triplaris surinamensis from Várzea, (D) Eschweilera albiflora from Várzea, (E) Crescentia alata from La Pacifica and (F) Amphirrhox surinamensis from Igapó. 
RELATIONSHIPS BETWEEN WOOD ANATOMICAL VARIABLES Across all individuals, species and sites, the following wood anatomical variables showed multiple and highly significant inter-correlations (Table 4): Vessel frequency (VF) was negatively correlated with vessel diameter (VD) and vessel area (VA). A positive correlation was found between vessel size (VD \& VA, respectively) and the distance between neighbouring vessels (DNN). A negative correlation was observed between DNN and VF. Vessel cross-sectional area (VCA) is significantly and positively correlated with VF but not with vessel size. Consequently we observed a negative correlation of VCA with fibre (FCA) and - more strongly - with parenchyma cross-sectional area (PCA) as those measures are complementary. Among the three cross-sectional area variables the (negative) correlation between PCA and FCA was the strongest. Additional correlations between cross-sectional area values were all related to variation in VD and VF and associated changes in VCA.

Hydraulic variables which describe water transport efficiency and water transport safety, such as vulnerability index (VI), vessel composition index (S) and theoretical hydraulic conductivity $\left(\mathrm{K}_{\mathrm{t}}\right)$ were correlated with vessel size and frequency. Vessel lumen fraction $(\mathrm{F})$, a measure of the quantity of vessel tissue was only correlated with VF, calculated $\mathrm{F}$ shows nearly identical values as measured vessel cross-sectional area $\left(\mathrm{F} \approx \mathrm{VCA} * 10^{-2}\right)$.

In summary, VD and VA showed the strongest correlation with all other vessel variables. Furthermore VD and VA are determinant factors for the calculated indices. These two vessel variables are highly correlated $(r=0.98, p<0.001)$, therefore vessel diameter was chosen as proxy in the presentation of all subsequent analyses, to reduce the iteration of analogous results.

\section{RELATIONSHIPS BETWEEN WOOD ANATOMICAL VARIABLES WITH INDIVIDUAL TREE} MORPHOLOGY AND TREE AGE All tree growth related variables such as ring widths, tree height, stem diameter and crown exposure were significantly and strongly correlated among each other ( $c f$. Table 4). Tree growth in height, diameter and of the crown were negatively correlated with vessel frequency and positively correlated with vessel diameter. Consequently, positive correlations were found with calculated hydraulic indices that describe water transport efficiency (VI, S, $\mathrm{K}_{\mathrm{t}}$ ) and tree growth, while vessel lumen fraction was only weakly negatively correlated with ring width. No significant correlations were found between ring ages (RA) and vessel variables or calculated hydraulic indices; however RA was negatively correlated with ring width (RW) and positively correlated with $\mathrm{DBH}$, height and CE. 


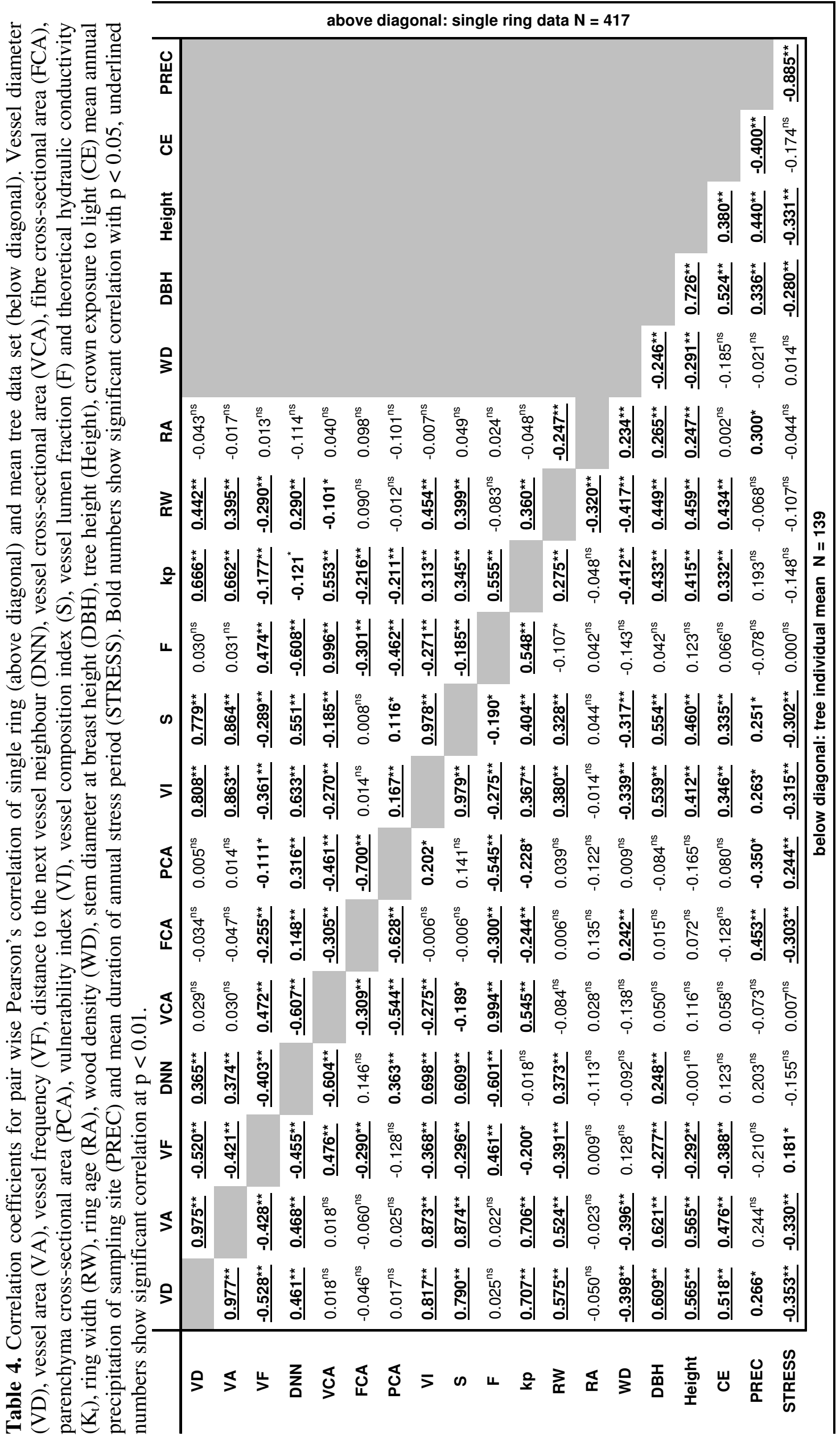


Wood density (WD) showed negative correlations to vessel diameter and area as well as to VI, S and $\mathrm{K}_{\mathrm{t}}$. WD was also positively correlated with fiber cross-sectional area and ring age, while growth related parameters showed negative (RW, DBH and height) or no (CE) correlations with WD.

\section{RELATIONSHIPS BETWEEN WOOD-ANATOMICAL TRAITS AND TREE GROWTH TO} CLIMATE VARIABLES Between the mean annual precipitation (PREC) at the non-flooded sites and wood anatomical variables only a weak positive correlation was found for VD, but a less significant one with VI and S. The most significant and strongest correlation with PREC was observed for fiber cross-sectional area. The opposite relation between parenchyma crosssectional area and PREC was weaker and less significant. A positive correlation between ring age and PREC was noteworthy as well as the correlation between rainfall and tree morphology (DBH, Height \& CE).

The duration of STRESS exhibited opposite relations to wood traits and tree morphology compared to PREC. STRESS showed a significant negative correlation with VD and VA, VI, S as well as a positive correlation with VF. STRESS showed weaker negative correlations with FCA and a positive relation with PCA. Finally we observed a negative correlation between tree size and STRESS. With regard to independent parameters, vessel diameter and vessel area showed the most consistent relations.

\section{VARIATION IN WOOD ANATOMICAL VARIABLES WITHIN AND BETWEEN FAMILIES AND}

SITES Within all groups, both families and sites, we could observe a high variability of vessel diameter (Fig. 2). Basically, we observed an increase of variation with increasing number of individuals within a group. Within the category 'plant family' we observed the highest variation of vessel diameter within the pan-tropical family Fabaceae, a group with a high number of species and individuals. Lauraceae and Myrtaceae showed the lowest variation in vessel diameter. Significant difference with respect to VD could only be observed between Malvaceae (largest VD) and three other plant families showing smaller VD and lower variability (Annonaceae, Bignoniaceae and Myrtaceae; Fig. 3, left).

Looking at different groups in terms of different sites, again we did observe the highest variation in VD in groups with a higher number of individuals. Between the different sites (not shown) no significant differences between mean vessel diameters could be detected.

As we observed a correlation between climate variables and wood traits, we defined three categories for stress level $(1=$ stress periods lasting less than 10 weeks long, $2=$ stress 
period lasting between 10 to 20 weeks long and $3=$ stress periods lasting longer than 20 weeks). Independent from family, trees experiencing a long stress period of more than 25 weeks showed significant smaller VD compared to trees from less stressed sites (Fig. 3, right).
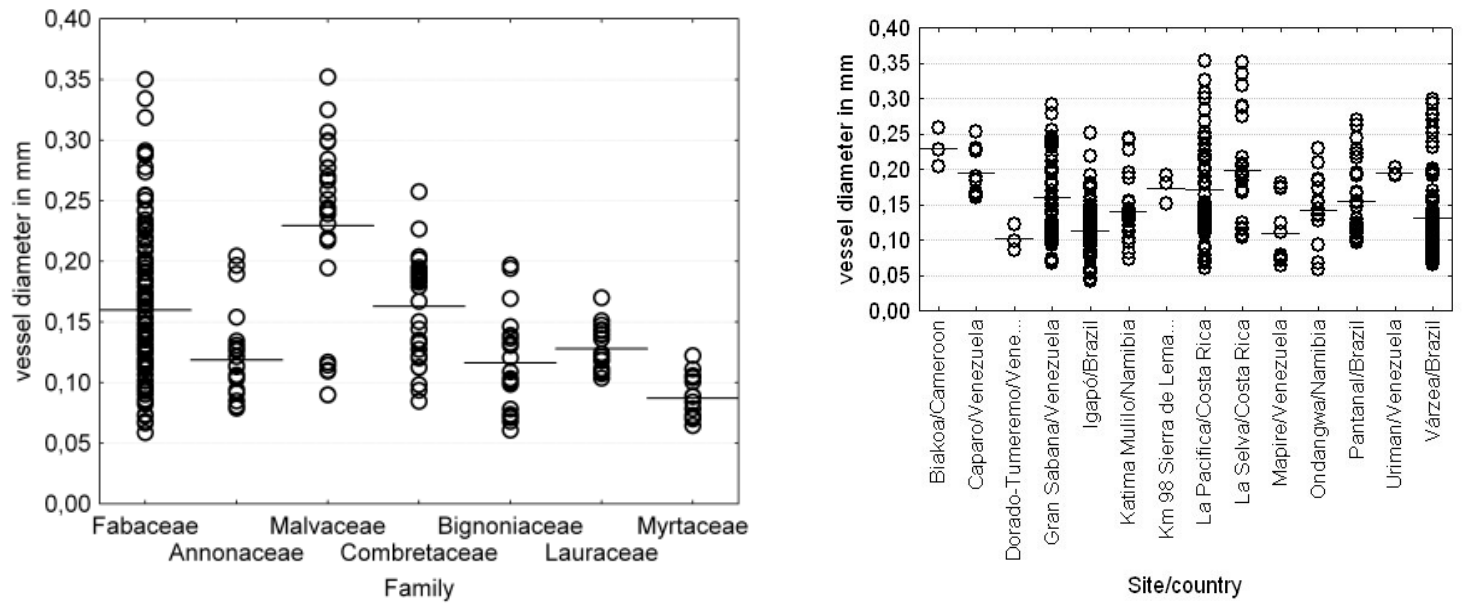

Figure 2. Statistical spread of the vessel diameter for trees grouped into families (left, displayed are only families represented by five and more tree individuals) and into different sites (right, all samples). Open circles show original data, lines show means for the different groups.
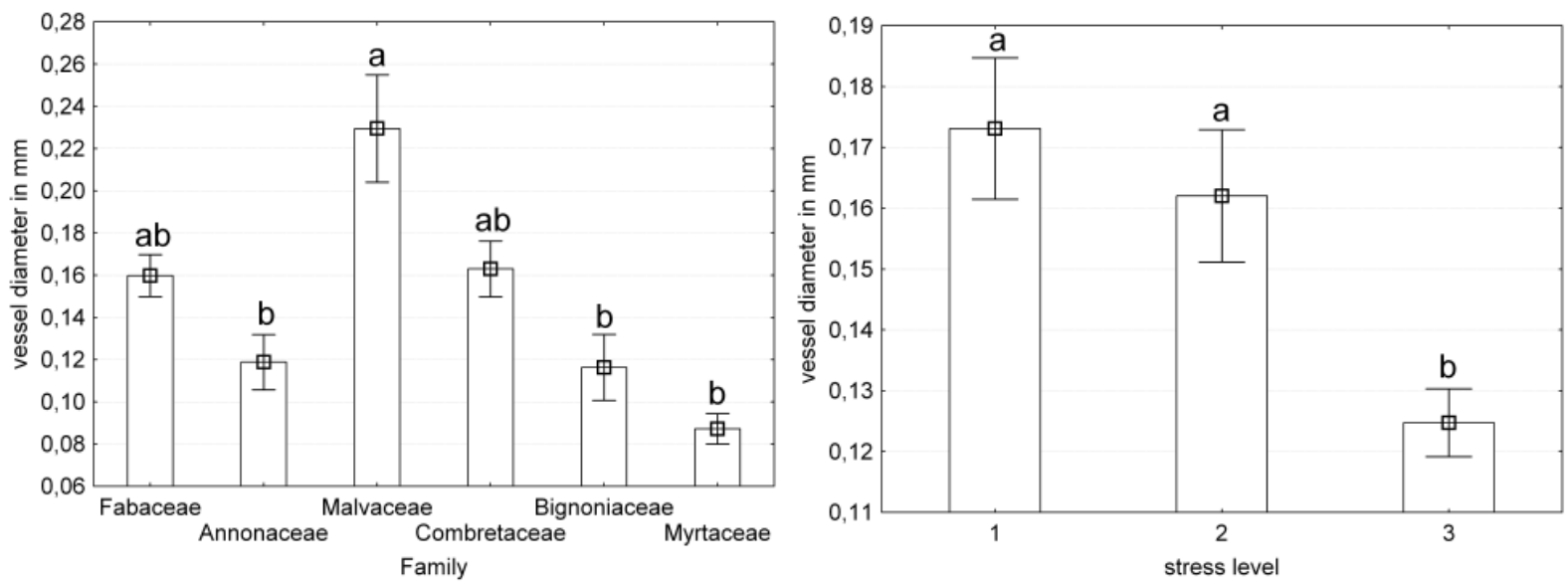

Figure 3. The effect of plant family (left) and of STRESS (right; as the duration of stress period in three different levels) on vessel diameter of tropical trees. All bars represent means $( \pm$ SE; $N=139)$. Groups sharing the same superscript letter are not significantly different, $\mathrm{p}<0.05$, Tukey's HSD test (displayed on the left side are only those families that were represented by at least five individuals). 
The comparison of groups formed by attributes of tree morphology (DBH, height \& $\mathrm{CE}$ ) revealed clear differences between categories (Fig. 4). VD was significantly larger in big, compared to small trees. The same was true for canopy tree individuals compared to suppressed trees and for large diameter trees compared to individuals with small diameters.
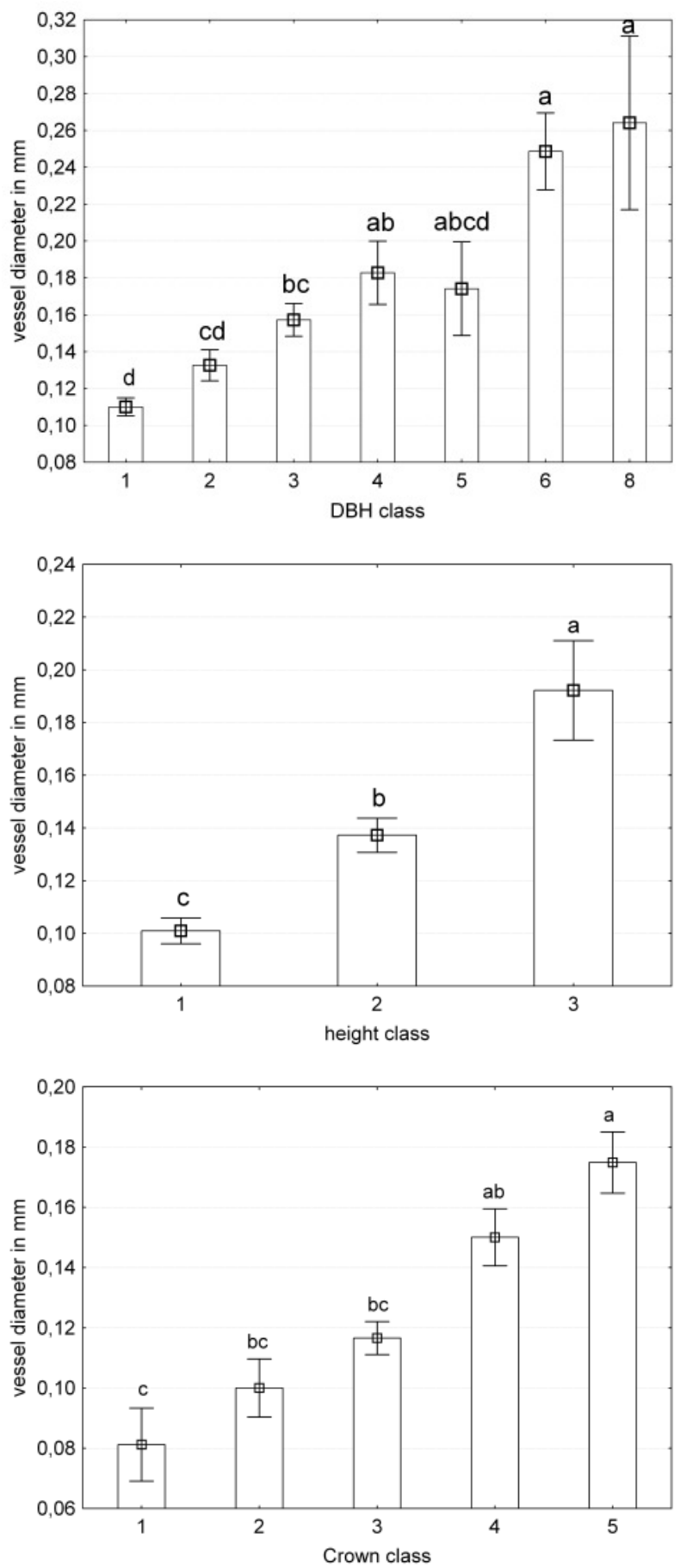

Figure 4. The effect of stem diameter (in classes of $10 \mathrm{~cm}$ steps, class $1=5-15 \mathrm{~cm} ; \mathrm{N}=139$ ), tree height $(1=<10 \mathrm{~m}, 2=10 \mathrm{~m}$ to $20 \mathrm{~m}, 3=>20 \mathrm{~m} ; \mathrm{N}=97)$ and crown exposure $(1-5,1=$ totally in shade up to $5=$ full exposure; $\mathrm{N}=114$ ) on vessel diameter of tropical trees. All bars represent means $( \pm$ SE). Groups sharing the same superscript letter are not significantly different, $p<0.05$, Tukey's HSD test. 
Principal COMPONEnT ANALYSIS We analyzed the relation between wood anatomical variables and independent variables such as tree growth (DBH and RW), phylogenetic source (FAM) and macro climate (STRESS, Fig. 5) using principal component analysis. In figure 5, the vectors reflect the strength of the influence of individual variables on the overall variance of the sample set. Similar loading positions thus represent analogous influences. The first axis of the complete sample set (Fig. 5) explained $34.26 \%$ of the total variance and showed strong positive loadings for tree growth (DBH and RW) associated with variables of water transport efficiency (VD, VA, S and VI) and a strong negative loading for vessel frequency (VF). The second axis explained $19.80 \%$ of the variance and showed strong positive loadings for vessel cross-sectional area (VCA \& F) and strong negative loadings for parenchyma cross-sectional area (PCA). $\mathrm{K}_{\mathrm{t}}$ had a strong positive loading on both axes and DNN a strong positive loading on the first axis, but a strong negative one on the second axis. The duration of stress period (STRESS, first axis), phylogenetic source (FAM, first axis), wood density (WD, both axes) and fiber cross-sectional area (FCA, second axis) showed only weak loadings, while ring age (RA) was not explained at all by the first two axes in the complete sample set. Two more relevant axes showed Eigenvalues larger than 1, indicating axes that explain more variance than each individual variable contributes: The third axis explained $11.50 \%$ of the total variance with a strong positive loading for the parenchyma cross-sectional area combined with a moderate positive loading for the duration of STRESS, while the fiber cross-sectional area showed a strong negative loading. The fourth axis explained $7.80 \%$ of total variance with strong positive loadings for RA and a moderate negative signal for RW. 

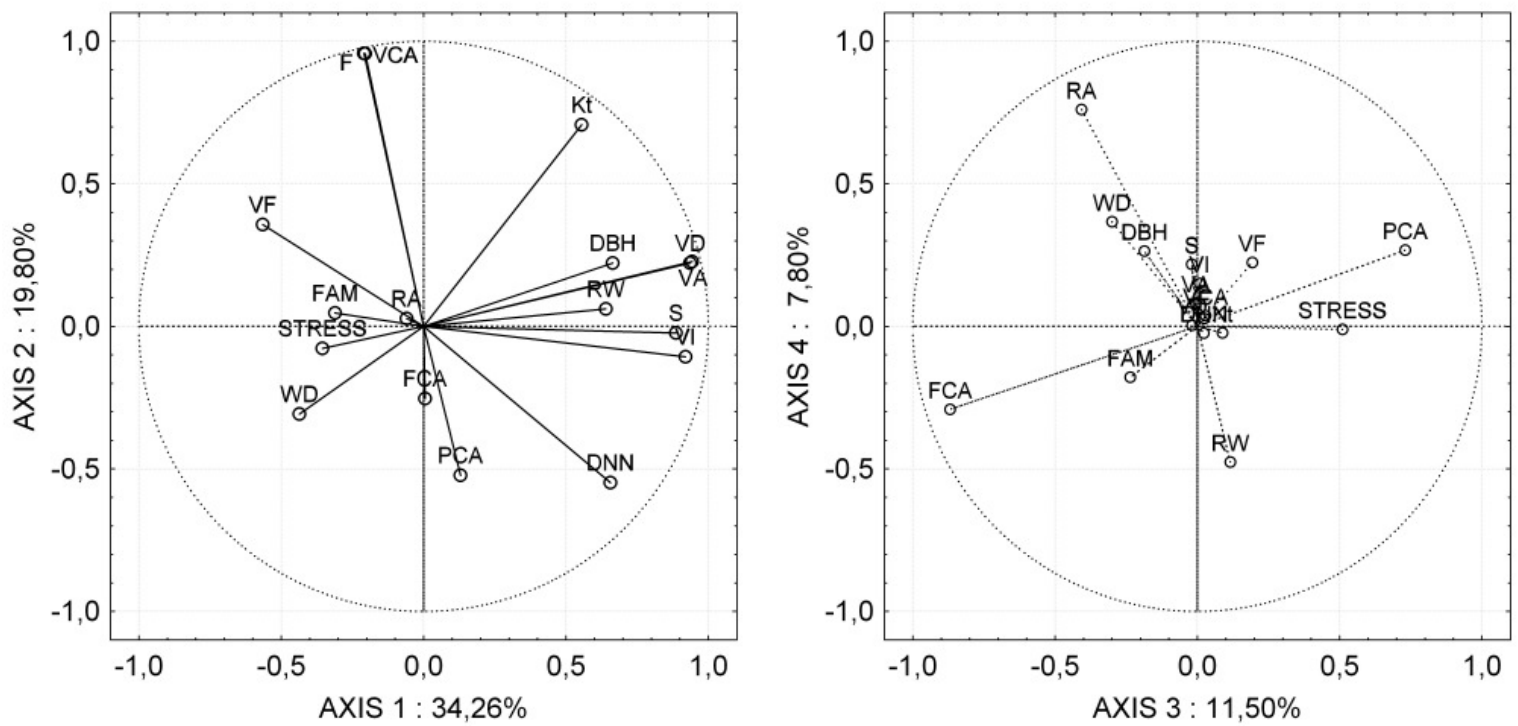

Figure 5. Principal component analysis of 17 different variables for the complete sample set $(\mathrm{N}=139)$.On the left side the first two axes are shown, on the left side two more relevant axes are displayed. Included were 14 wood traits: vessel diameter (VD), vessel area (VA), vessel frequency (VF), distance to the next vessel neighbour (DNN), vessel cross-sectional area (VCA), fibre crosssectional area (FCA), parenchyma cross-sectional area (PCA), ring width (RW), ring age (RA), vulnerability index (VI), vessel composition index (S), vessel lumen fraction (F) and theoretical hydraulic conductivity $\left(\mathrm{K}_{\mathrm{t}}\right)$. In addition we included tree diameter $(\mathrm{DBH})$ as an indicator of tree morphology, the plant family as phylogenetic source (FAM) and macroclimatic site conditions (STRESS).

Analyzing different sub-sample sets, revealed only slight deviations to the complete sample set (Fig. 6). In all groups, the strong influence of tree morphology was evident along the first axis linked with parameters associated with efficient water conduction explaining major components of the variance. In the comparison of flooded versus non-flooded trees, a reverse position of FCA related with PREC on the second axis was evident together with strong negative loadings for STRESS coupled with PCA in the non-flooded trees.

Fabaceae were represented with the highest number of individuals and species but also covered the most sites. In the separate principal component analysis for Fabaceae the general patterns and relations of the complete sample set were retrieved, but above all the influence of STRESS (second-rank in the complete data set) became considerably stronger along on the first axis, especially on $\mathrm{K}_{\mathrm{t}}$ and $\mathrm{DBH}$. The same analysis for Combretaceae represented by fewer individuals (only two genera) but along a large precipitation gradient on non-flooded sites, discovered an even clearer influence of tree morphology on the water transport system (along the first axis) but in addition discovered a strong influence of climate on the different tissue components. Finally, RA loaded stronger on both axes in all sub-sample analyses. 

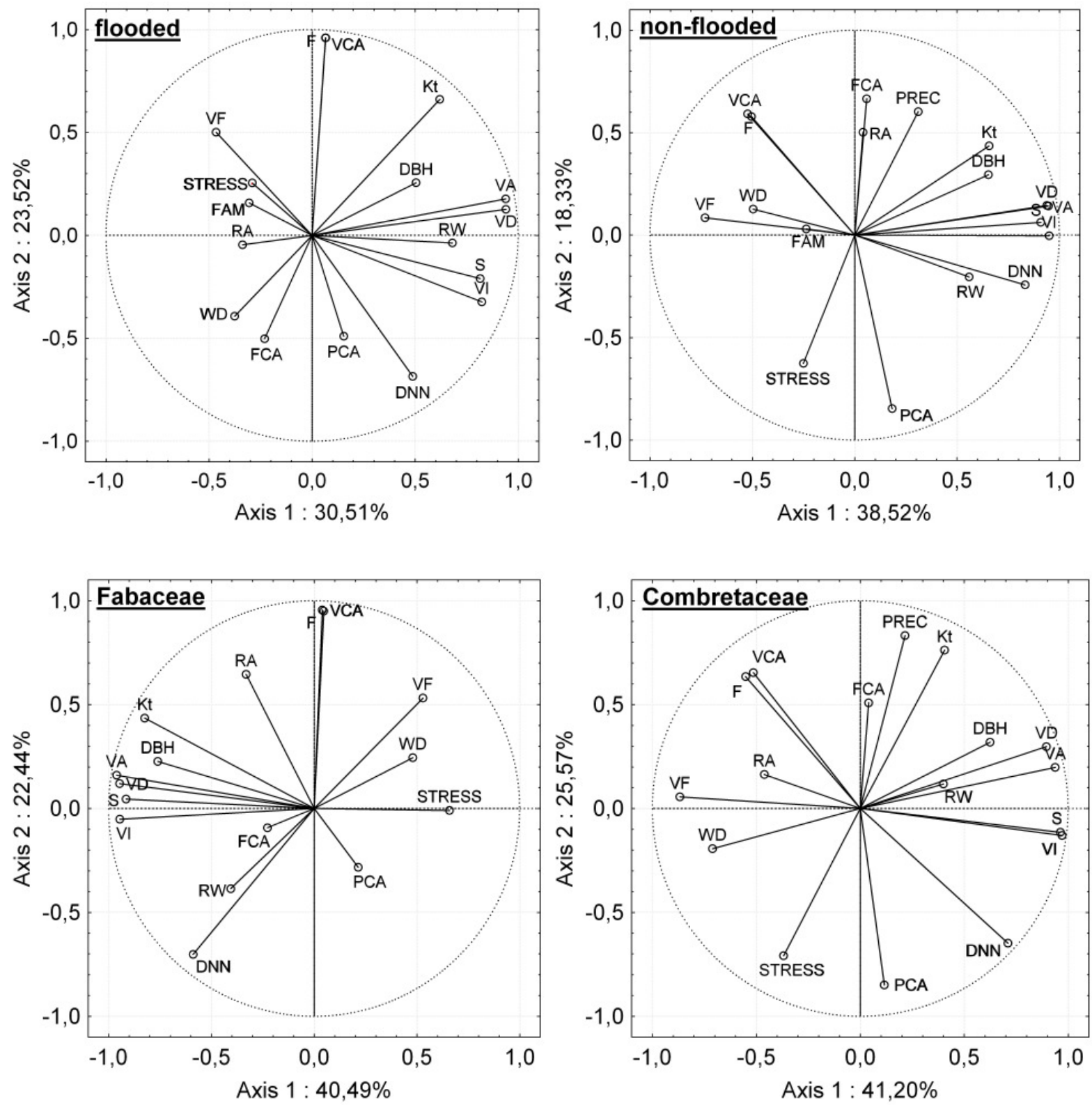

Figure 6. Principal component analysis of 17 different variables for sub-sample sets (flooded, nonflooded, Fabaceae, Combretaceae). Included were 14 wood traits: vessel diameter (VD), vessel area (VA), vessel frequency (VF), distance to the next vessel neighbour (DNN), vessel cross-sectional area (VCA), fibre cross-sectional area (FCA), parenchyma cross-sectional area (PCA), ring width (RW), ring age (RA), vulnerability index (VI), vessel composition index (S), vessel lumen fraction (F) and theoretical hydraulic conductivity $\left(\mathrm{K}_{\mathrm{t}}\right)$. In addition we included tree diameter $(\mathrm{DBH})$ as an indicator of tree morphology, the plant family as phylogenetic source (FAM) and macroclimatic site conditions (STRESS). In non-flooded sub samples (non-flooded \& Combretaceae) PREC was added in the analysis. 


\section{DISCUSSION}

The diversity of wood anatomical structures in tropical trees mirrors the principal species richness in the tropics and is the subject of numerous articles and books (e.g. Carlquist 2001; Wheeler et al. 1989, 2007). The specific wood structure together with sub-cellular features is related to higher taxonomical units and enables the determination of family and genus of a sample from an anatomical analysis alone (e.g. Evans et al. 2006). However, the anatomical assignment is impeded by a high plasticity of the wood structure within one species or even a single individual (Worbes 1988), which is supposed to be the result of the influence of varying environmental and developmental factors.

For a deeper understanding of the relations between external factors and wood structure we analyzed a number of wood anatomical variables of tropical trees across taxa and a wide climatic gradient. We combined the results with a unique data set on climate, site and forest stand conditions. We tested the variation of vessel characteristics and the relation of parenchyma- and fibre-tissue on the base of individual tree rings of varying widths.

Apart from vessel characteristics, which are measured directly, a couple of derived estimates have been considered like vessel composition index (S; Zanne et al. 2010), vessel lumen fraction (F; Zanne et al. 2010), vulnerability index (VI; Carlquist 1977) and theoretical hydraulic conductivity ( $\mathrm{K}_{\mathrm{t}}$; cf. Tyree \& Zimmermann 2002). VI, S and $\mathrm{K}_{\mathrm{t}}$ consider both, vessel size (VD or VA) and number (VF) and therefore give an indication of the quantitative attributes of the water transport system in the stem. S corresponds strongly to VI, and F approximates the measures of vessel cross- sectional area, albeit on another order of magnitude. Concerning the work load of quantitative wood anatomical analyses calculating $\mathrm{F}$ is in advantage over measuring VCA. Our multivariate analysis, however, shows that these calculated indices do not explain more variation and relations with external factors than the basic and directly measured parameters. In general vessel diameter showed the strongest and most significant correlation with other wood anatomical variables, climate parameters and tree morphology.

RELATIONSHIPS BETWEEN DIFFERENT WOOD VARIABLES One obvious result in analysing the relations between the measured anatomical parameters is that vessel size (VD and VA) and frequency are significantly negative correlated, a very well-known phenomenon (Baas 1973, Carlquist 1975). This finding mirrors two contrasting concepts of water transport 
systems (Fig 7). Basically wide vessels are the most efficient water conductors (Baas et al. 1983) since the water conductivity increases with the fourth power of vessel diameter and only with the first power of vessel frequency (Tyree \& Zimmermann 2002). The ecological disadvantage of the large vessels is their vulnerability against cavitation (Choat et al. 2005). In contrast a high number of narrow vessels providing a similar water transport capacity like a small number of wide vessels is much safer in terms of vulnerability: the drop out of single vessels through embolisms does not endanger the entire conductive system since many other conduits are still left to supply the tree's crown with water (Baas et al. 2004). This trade-off between efficiency and safety is eminently described by the first axis of the principal component analysis of the complete sample set and is evident in all subsequent sample sets (flooded, non-flooded, different individual plant families).

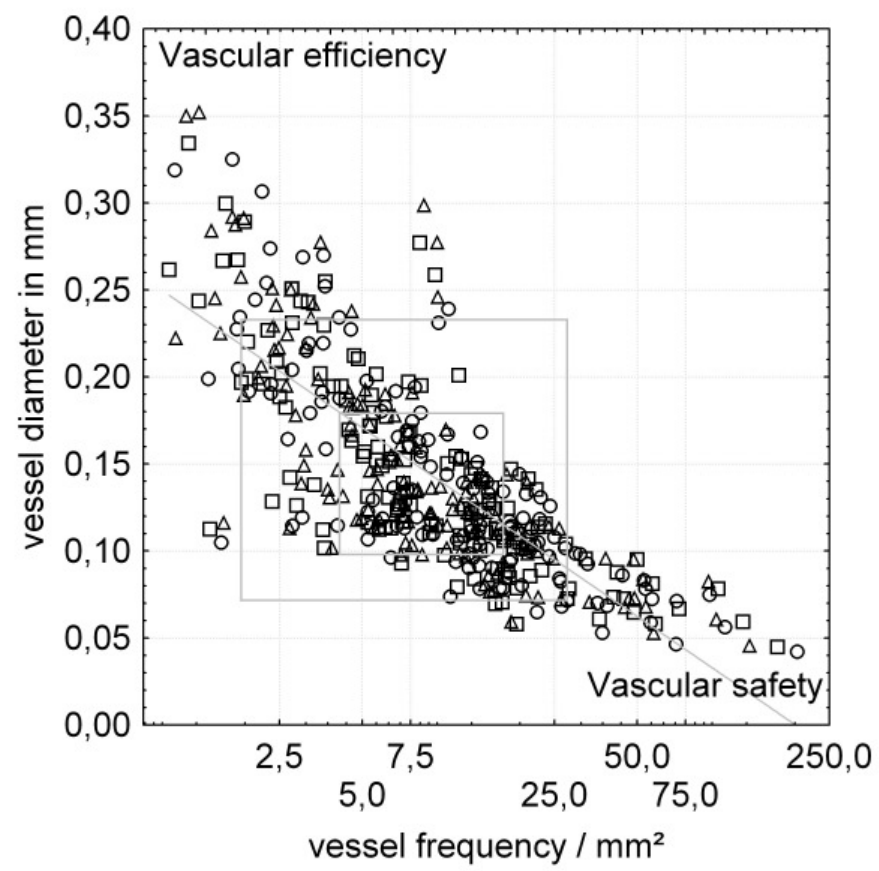

Figure 7. Relation between vessel diameter and vessel frequency exhibiting the trade-off between vascular efficiency and safety; boxes indicate the $25 \%$ and $75 \%$ quartile (inner) and the $10 \%$ and 90 $\%$ percentile (outer) of VD and VF. Different symbols indicate different ring-size categories (circle $=$ narrow, squares $=$ average, triangle $=$ wide $)$. Note log-transformed scale for vessel frequency.

\section{RELATIONSHIPS BETWEEN WOOD VARIABLES AND RING WIDTH AND TREE}

MORPHOLOGY In general, vessel diameter is strongly positively correlated with mean ring widths. Consequently we found close correlations between VD and all tree morphological parameters (DBH, height, CE) as these are positively inter-correlated (Hart 2010). The principal component analysis also showed the correlation between tree size and an efficient 
water transport system. This relation is necessary to provide the large leaf area of a tall and dominant tree with water for transpiration and photosynthesis.

A negative correlation between wood density and ring width and respectively growth rate has been observed at site and ecosystem level (Worbes et al. 2003; Müller-Landau 2004; Preston et al. 2006; Poorter et al. 2010) and is also highly significant across all our sites and species. This observation simply means that representatives of the contrasting life strategies extremely fast growing pioneer and moderately growing mature forest tree as well as extremely slow growing understorey trees- are included in our sample set (Swaine \& Whitmore 1988). Pioneer species, for example, invest in fast radial and height growth at the expense of stability and longevity (Santiago et al. 2004; Kraft et al. 2010).

To maintain the water balance with increasing tree height in particular in canopy trees adaptations in the hydraulic architecture are needed. Taller trees have longer path lengths and therefore need wider vessels to maintain sufficient hydraulic conductivity (Coomes et al. 2008): forming larger vessels counteracts a decreasing loss in water supply due to longer flow pathways, increasing gravitational forces and hydraulic resistance (Mencuccini \& Magnani 2000). Cavitation risk in tall trees can also be minimized by the co-existence or the substitution of adaptations in other organs or in physiological processes (Lindorf 1994), e.g. xeromorphic leaf structure, succulence, deciduousness, deep or extensive root system or special photosynthetic pathways (Sobrado 1993; Brodribb et al. 2003; Choat et al. 2005).

RELATION OF WOOD ANATOMICAL VARIABLES TO CLIMATIC SITE CONDITIONS In mOSt tree individuals we observed a high plasticity of vessel characteristics. This means that the plasticity is given for all species and sites. As Eckstein (2004) reports that vessel variables store an environmental signal different from that in ring width and density, annual variability of these parameters should be studied in direct relation to annual climate variability.

In general we found a high variation of different anatomical variables between species at given sites which was greater than the average variation across sites ( $c f$. the two Costa Rican sites which differ considerably in climate conditions (a dry and a perhumid forest, Fig 2 , right). These high variations indicate the co-existence of different strategies in the vascular design of the stem. Major properties that are hydraulically relevant such as vessel structure, leaf stomatal behaviour or the kind of root system, generally define the range of a species' tolerance and competitiveness and thus the ecological setting to which a species is adapted (Fonti et al. 2010). Trees growing at stressed sites are said to require a shift towards safety in 
the water conducting system (Tyree et al. 1994), leading to smaller vessel diameters. Although a high variability was observed at all sites, we found a positive relation between vessel dimensions and the general precipitation regime. Moreover we could observe a stronger influence of the parameter STRESS (the length of the stress period) which we developed to include trees from flooded as well as those from non-flooded sites in our analysis. Trees from both ecosystems react equally to longer stress periods, and independently from the nature of the stress, with the formation of significantly smaller vessel diameters. The vegetation period in stressful environments is considerably shorter and forces the trees to perform all important physiological processes that ensure growth, reproduction and survival in a very constricted time frame. These constraints demand a water transport system that ensures maximum efficiency at the lowest possible cavitation risk. Thereby deciduous tree species avoid stress by shedding their leaves, possibly allowing lower cavitation resistance and larger vessels, while evergreen species can tolerate unfavourable growing conditions possibly due a higher cavitation resistance with smaller vessels (cf. Choat et al. 2005) and by slowing down or stopping physiological processes (Worbes 1985; Schöngart et al. 2002). Survival and competitiveness of tree species depend on their general stress avoidance strategy but also on their ability to adjust and optimize their hydraulic architecture by differences in vessel size and frequency to varying environmental conditions from year to year (Fonti et al. 2010). We conclude that the lower vessel diameter range observed at stressed sites can be traced back to extreme macro-climatic site conditions. The high variation of VD within these sites can be attributed to different plant strategies and the strong impact of individual tree morphology.

The third axis of the principal component analysis of the complete sample set and the second axis in the sub-sets indicate a strong relation between parenchyma cross-sectional area and the magnitude of stress. In contrast, fibre cross-sectional area loaded negative on this axis (at non-flooded sites associated with the amount of precipitation). This observation reflects the trade-off between growth and survival: The investment in parenchyma at stressed sites guarantees a better and faster supply with reserves promoting a fast flushing and production of early wood at the beginning of a short vegetation period (Fink 1982; Dünisch \& Puls 2003). That means that the investment in parenchyma is not random, but clearly reflects the mechanisms of carbohydrate storage and mobilization as a function of specific phenological behaviour triggered by the dominating and limiting external growth factor. In addition, a higher amount of parenchyma cells may be important in refilling mechanisms of cavitated vessels (Brodersen et al. 2010). Therefore trees at less stressed sites seem to be able to invest 
more carbon in fibre cell structures that promise protection against mechanical and chemical forces while stressed sites require more investment in parenchyma structures to ensure better growth. So far, only little is known on the ecological significance of these relevant wood anatomical variables (Poorter et al. 2010) and therefore the observed direct influence of climate on the parenchyma and fibre cross sectional area gives direction to future analyses, which should also consider presence or absence of living, septate fibres that can take over the function of axial parenchyma and are very common in tropical woods (Wheeler et al. 2007).

RELATION OF WOOD VARIABLES TO PHYLOGENETIC BACKGROUND We compared vessel diameter within and between different families and observed a high variation of this parameter within families, especially within those with a pan-tropical distribution as Fabaceae or Combretaceae. Besides that, we observed significant differences between some families. Thereby the vessels of Malvaceae were on average significantly larger while e.g. Myrtaceae and Annonaceae showed significantly smaller vessel diameters than other families. Above we argued that vessel variables are closely related to tree morphology, while the phylogenetic influence appeared to be relatively weak ( $c f$. principal component analyses). Most trees within the Malvaceae are large fast growing stem-succulent trees with a very spongy wood structure caused by a comparably high number of large vessels that are surrounded by very thin-walled fibre tissue showing a totally different plant strategy compared to all other families. Moreover, in tropical forests many ecological niches exist first of all by different canopy strata. Representatives of the Myrtaceae and Annonaceae are typical elements of the understorey appearing as small and thin trees. Therefore these differences can be traced back to the delimited ecological niches these families occupy rather than to taxonomic characteristics. In contrast, larger plant families (e.g. Fabaceae or Combretaceae) are represented through all strata and therefore show a higher variability of vessel diameters. Following tree morphology the influence of general climate conditions on wood anatomical variables is of great importance: this second influencing factor also determines variation in VD and therefore contributes to the observed higher variability in families with a pan-tropical distribution. 


\section{CONCLUSION}

We found high within-species and high within-site variation of wood anatomical variables which were greater than between-species and -site variation. Thereby vessel diameter showed the strongest and most significant correlations to other wood anatomical variables, but also to tree morphology and climate parameters. We could observe that general climate conditions influence vessel size and tissue composition of trees, but even stronger was the influence of tree morphology on vessel size and consequently on the hydraulic architecture of the stem.

Plant growth and survival is shaped by a multitude of root, stem and leaf characteristics and influenced by environmental site and stand-specific conditions. The interrelation of these factors might shift depending on phylogenetic constraints, individual tree morphology as well as climate variability. To further encode the strength of the influencing factors of wood anatomical variables future analyses should be based on the comparison of different plant families. Within a certain range that is dominantly influenced by tree morphology individual trees show a high plasticity of wood anatomical variables. Therefore future dendrochronological studies should consider a direct link between this variability of wood anatomical structures with short term oscillating environmental changes.

\section{ACKNOWLEDGEMENTS}

We thank Ute Ronsöhr for help with sample photography, Oyunsanaa Byambasuren for help with colour-coding of images. Britta Eilmann, Valerie Trouet \& Ute Sass-Klaassen as well as two anonymous reviewers and Pieter Baas provided helpful comments on the manuscript. E. Fichtler was sponsored by the Scholarship Programme of the German Federal Environmental Foundation (DBU). 


\section{REFERENCES}

Ackerly, D.D. 2003. Community assembly, niche conservatism, and adaptive evolution in changing environments. Int. J. Plant Sci. 164: S165-S184.

Baas, P. 1973. The wood anatomical range in Ilex (Aquifoliaceae) and its ecological and phylogenetic significance. Blumea 21: 193-258.

Baas, P., E.A. Wheeler \& A. Fahn. 1983. Some ecological trends in vessel characters. IAWA Bull. 4: 141-159.

Baas, P., F.W. Ewers, S.D. Davis \& E.A. Wheeler. 2004. Evolution of xylem physiology. In: Hemsley, A.R. \& I. Poole (Eds.) The Evolution of Plant Physiology: 273-295. Published for the Linnean Society of London by Elsevier Academic Press, Amsterdam, Boston.

Baraloto, C., C.E.T. Paine, L. Poorter, J. Beauchene, D. Bonal, A.M. Domenach, B. Herault, S. Patiño, J.C. Roggy \& J. Chave. 2010. Decoupled leaf and stem economics in rain forest trees. Ecology Letters 13: 1338-1347.

Bosio, F., P. Soffiatti \& M.R. Torres Boeger. 2010. Ecological wood anatomy of Miconia sellowiana (Melastomatsceae) in three vegetation types of Parána State, Brazil. IAWA J. 31: 1979-190.

Brodersen, C.R., A.J. McElrone, B. Choat, M.A. Matthews\& K.A. Shackel. 2010. The Dynamics of Embolism Repair in Xylem: In Vivo Visualizations Using HighResolution Computed Tomography. Plant Physiol. 154: 1088-1095.

Brodribb T.J., N.M. Holbrook, E.J. Edwards \& M.V. Gutierrez. 2003. Relation between stomatal closure, leaf turgor and xylem vulnerability in eight tropical dry forest trees. Plant Cell Environ 26: 443-450.

Carlquist, S. 1975. Ecological strategies of xylem evolution. University of California Press. Berkeley, Los Angeles, London.

Carlquist, S. 1977. Ecological factors in wood evolution: a floristic approach. Am. J. Bot. 64: 887-896.

Carlquist, S. 2001. Comparative Wood Anatomy. Systematic, ecological, and evolutionary aspects of dicotyledon wood. 2nd, completely revised edition. Springer, Berlin Heidelberg, NewYork.

Cavender-Bares, J., K. Kitajima \& F.A. Bazzaz. 2004. Multiple trait associations in relation to habitat differentiation among 17 Floridian oak species. Ecol. Monogr. 74: 635-662. 
Chave, J., D. Coomes, S. Jansen, S.L. Lewis, N.G. Swenson \& A.E. Zanne. 2009. Towards a worldwide wood economics spectrum. Ecology Letters 12: 351-366.

Choat, B., M.C. Ball, J.G. Luky, J.A.M. Holtum. 2005. Hydraulic architecture of deciduous and evergreen dry rainforest tree species from north-eastern Australia. Trees 19: 305311.

Choat, B., L. Sack \& N.M. Holbrook. 2007. Diversity of hydraulic traits in nine Cordia species growing in tropical forests with contrasting precipitation. New Phytol. 175: 686-698.

Choat, B., A.R. Cobb \& S. Jansen. 2008. Structure and function of bordered pits: new discoveries and impacts on whole-plant hydraulic function. New Phytol.177: 608-626.

Coomes, D.A., S. Heathcote, E.R. Godfrey, J.J. Shepherd \& L. Sack. 2008. Scaling of xylem vessels and veins within the leaves of oak species. Biological Letters 4: 302-306.

Dezzeo, N., M. Worbes, I. Ishii \& R. Herrera. 2003. Annual tree rings revealed by radiocarbon dating in seasonally flooded forest of the Mapire River, a tributary of the lower Orinoco River, Venezuela. Plant Ecol. 168: 165-175.

Dünisch, O. \& J. Puls. 2003. Changes in content of reserve materials in an evergreen, a semideciduous, and a deciduous Meliaceae species from the Amazon. J. Appl. Bot. 77: 1016.

Eckstein, D. 2004. Change in past environments - secrets of the tree hydrosystem. New Phytol. 163: 1-4.

Evans, J.A., P.E. Gasson \& G.P. Lewis. 2006. Wood antomy of the Mimosoideae (Leguminosae). IAWA J. suppl. 5. International Association of Wood Anatomists, National Herberium Nederland, the Netherlands.

Fichtler, E., D.A. Clark \& M. Worbes. 2003. Age and long-term growth of trees in an oldgrowth tropical rain forest, based on analyses of tree rings and 14C. Biotropica 35: 306-317.

Fichtler, E., V. Trouet, H. Beeckman, P. Coppin \& M. Worbes. 2004. Climate signals in tree rings of Burkea africana and Pterocarpus angolensis from semiarid forests in Namibia. Trees 18: 442-451.

Fink, S. 1982. Histochemical investigations on starch-distribution and activity of acidphosphatases in the xylem of some tropical tree species. Holzforschung 36: 295-302.

Fonti, P., G. von Arx, I. García-González, B. Eilmann, U. Sass-Klaassen, H. Gärtner \& D. Eckstein. 2010. Studying global change through investigation of the plastic responses of xylem anatomy in tree rings. New Phytol. 185: 42-53. 
Fritts, H.C. 1976. Tree rings and climate. Academic Press London, New York, San Francisco.

Garcia-Gonzales, I. \& D. Eckstein. 2003. Climatic signal of earlywood vessels of oak on a maritime site. Tree Physiol. 23: 497-504.

Hacke, U.G., J.S. Sperry, W.T. Pockman, S.D. Davis \& K.A. McCulloch. 2001. Trends in wood density and structure are linked to prevention of xylem implosion by negative pressure. Oecologia 126: 457-461.

Hart, P.J. 2010. Tree growth and age in an ancient Hawaiian wet forest: vegetation dynamics at two spatial scales. J. Trop. Ecol. 26: 1-11.

Kraft, N.J.B., M.R. Metz, R.S. Condit \& J. Chave. 2010. The relationship between wood density and mortality in a global tropical forest data set. New Phytol. 188: 1124-1136.

Lindorf, H. 1994. Eco-anatomical wood features of species from a very dry tropical forest. IAWA J. 15: 361-376.

Lopez, O.R., T.A. Kursar, H. Cochard \& T.M. Tyree. 2005. Interspecific variation in xylem vulnerability to cavitation among tropical tree and shrub species. Tree Physiol. 25: $1553-1562$.

Martínez-Cabrera, H.I., C.S. Jones, S. Espino \& H.J. Schenk. 2009. Wood anatomy and wood density in shrubs: Responses to varying aridity along transcontinental transects. Am. J. Bot. 96: 1388-1398.

McCulloh, K., J.S. Sperry, B. Lachenbruch, F.C. Meinzer, P.B. Reich, \& S. Voelker. 2010. Moving water well: comparing hydraulic efficiency in twigs and trunks of coniferous, ring-porous, and diffuse-porous saplings from temperate and tropical forests. New Phytol. 86: 439-450.

Mencuccini, M. \& F. Magnani. 2000. Comment on 'Hydraulic limitation of tree height: a critique’ by Becker, Meinzer \& Wullschleger. Funct. Ecol. 14: 135-137.

Müller-Landau, H.C. 2004. Inter-specific and Inter-site Variation in Wood Specific Gravity of Tropical Trees. Biotropica 36: 20-32.

Ortiz, J., L. Hernández \& M. Worbes. 2006. Crecimiento radial de Tachigali y Terminalia en bosques de tierra baja al sureste de Venezuela. Acta Bot Ven 29: 211-234.

Plomion, C., G. Leprovost, \& A. Stokes. 2001. Wood Formation in Trees. Plant Physiol. 127: $1513-1523$.

Poorter, L. \& K. Kitajima. 2007. Carbohydrate storage and light requirements of tropical moist and dry forest tree species. Ecology 88: 1000-1011.

Poorter, L., I. McDonald, A. Alarcón, E. Fichtler, J.C. Licona, M. Peña-Claros, F.J. Sterck, Z. Villegas \& U. Sass-Klaassen. 2010. The importance of wood traits and hydraulic 
conductance for the performance and life history strategies of 42 rainforest tree species. New Phytol. 185: 481-492.

Preston, K.A., W.K. Cornwell \& J.L. DeNoyer. 2006. Wood density and vessel traits as distinct correlates of ecological strategy in 51 California coast range angiosperms. New Phytol. 170: 807-818.

Rana, R., R. Langenfeld-Heyser, R. Finkeldey \& A. Polle. 2009. Functional anatomy of five endangered tropical timber wood species of the family Dipterocarpaceae. Trees 23: $521-529$.

Raschke, N. 2003. Baumartendiversität, Struktur und Biomassezuwachs der natürlichen Sekundärvegetation auf ehemahligen Weideflächen in Guancaste, Costa Rica. Staatsexamensarbeit . Tierärtzliche Hochschule Hannover.

Reich, P.B., I.J. Wright, J. Cavender-Bares, J.M. Craine, J. Oleksyn, M. Westoby \& M.B. Walters. 2003. The evolution of plant functional variation: Traits, spectra, and strategies. Int. J. Plant Sci. 164: S143-S164.

Santiago, L.S., G. Goldstein, F.C. Meinzer, J.B. Fisher, K. Machado, D. Woodruff \& T. Jones. 2004. Leaf photosynthetic traits scale with hydraulic conductivity and wood density in Panamanian forest canopy trees. Oecologia 140: 543-550.

Sass, U. \& D. Eckstein. 1995. The variability of vessel size in beech (Fagus sylvatica L.) and its ecophysiological interpretation. Trees 9: 247-252.

Schöngart, J., M.T.F. Piedade , S. Ludwigshausen, V. Horna \& M. Worbes. 2002. Phenology and stem-growth periodicity of tree species in Amazonian floodplain forests. J. Trop. Ecol. 18: 581-597.

Schweingruber, F.H. 1996. Tree rings and environment. Dendroecology. Birmensdorf, Swiss Federal Institute for Forest, Snow and Lanscape Research. Berne, Stuttgart, Vienna, Haupt.

Smith, K.T. 2008. An organismal view of dendrochronology. Dendrochronologia 26: 185193.

Sobrado, M.A. 1993. Trade-off between water transport efficiency and leaf life span in a tropical dry forest. Oecologia 96: 19-23.

Sperry, J.S. 2003. Evolution of water transport and xylem structure. Int. J. Plant Sci. 164: S115-S127.

Sperry, J.S, U.G. Hacke \& K.J. Wheeler. 2005. Comparative analysis of end wall resistivity in xylem conduits. Plant Cell Environ. 38: 456-465. 
Sperry, J.S., U.G. Hacke \& J. Pittermann. 2006. Size and function in conifer tracheids and angiosperm vessels. Am. J. Bot. 93: 1490-1500.

Staschel, R., M. Worbes \& A. Roloff. 1996. Wachstumsdynamik von Triplochiton scleroxylon (K. Schum.) in einem halbimmergrünen Naturwald in Kamerun. Verhandlungen der Gesellschaft für Ökologie 26: 183-188.

Swaine, M.D. \& T.C. Whitmore. 1988. On the definition of ecological species groups in tropical rain forests. Plant Ecol. 75: 81-86.

Tyree, M.T, S.D. Davis \& H. Cochard. 1994. Biosphysical perspectives of xylem evolution: is there a trade-off of hydraulic efficiency for vulnerability to dysfunction? IAWA J. 115: 335-360.

Tyree, M.T. \& M.H. Zimmermann. 2002. Xylem structure and the ascent of sap. Revised edition. Springer Berlin, Heidelberg York.

Wheeler, J.K., J.S. Sperry, U.G. Hacke \& N. Hoang. 2005. Inter-vessel pitting and cavitation in woody Rosaceae and other vesselled plants: a basis for a safety versus efficiency trade-off in xylem transport. Plant, Cell \& Environment 28: 800-812.

Wheeler, E.A., P. Baas \& P.E. Gasson. 1989. IAWA list of microscopic features for hardwood identification. IAWA J.Bull. n.s. 10: 219-332.

Wheeler, E.A., P. Baas \& S. Rodgers. 2007a. Variations in dicot wood anatomy: a global analysis based on the insidewood database. IAWA J. 28: 229-258.

Wimmer, R. 2002. Wood anatomical features in tree-rings as indicators of environmental change. Dendrochronologia 20: 21-36.

Worbes, M. 1985. Structural and other adaptations to long-term flooding by trees in Central Amazonia. Amazoniana 9: 459-484.

Worbes, M. 1988. Variety in structure of annual growth zones in Tabebuia barbata (E. Mey) Sandw., Bignoniaceae, a tropical tree species from Central Amazonian inundation forests. Dendrochronologia 6: 71-89.

Worbes, M. 1989. Growth rings, increment and age of trees in inundation forests, savannas and a mountain forest in the Neotropics. IAWA Bull. n.s. 10: 109-122.

Worbes, M. 1997. The forest ecosystem of the floodplains. In Junk, W. J. (ed.), The Central Amazon Floodplains. Ecology of a Pulsing System: 223-266. Springer-Verlag, New York, USA.

Worbes, M. 1999a. Annual growth rings, rainfall dependent growth and long-term growth patterns of tropical trees from the Forest Reserve Caparo in Venezuela. J. Ecol. 87: $391-403$. 
Worbes, M. 1999b. Degradación e historia de la vegetación boscosa de la Gran Sabana. Scientia Guaianae 9: 84-107.

Worbes, M. \& E. Fichtler. 2010. Wood Anatomy and Tree-Ring Structure and Their Importance for Tropical Dendrochronology. In: Junk, W.J.; Piedade, M.T.F.; Wittmann, F.; Schöngart, J. \& P. Parolin (eds.), Amazonian Floodplain Forests: Ecophysiology, Biodiversity and Sustainable Management: 329-346. Springer, Heidelberg.

Worbes, M., Klinge, H., Revilla J.D. \& C. Martius. 1992. On the dynamics, floristic subdivision and geographical-distribution of varzeá forests in central Amazonia. J. Veg. Sci. 3: 553-564.

Worbes, M., R. Staschel, A. Roloff \& W.J. Junk. 2003. Tree Ring Analysis Reveals Age Structure, Dynamics and Wood Production of a Natural Forest Stand in Cameroon. For. Ecol. Manage. 173: 105-123.

Wright, S.J., K. Kitajima, N.J.B. Kraft, P.B. Reich, I.J. Wright, D.E. Bunker, R. Condit, J.W. Dalling, S.J. Davies, S. Díaz, B.M.J. Engelbrecht, K.E. Harms, S.P. Hubbell, C.O. Marks, M.C. Ruiz-Jaen, C.M. Salvador \& A.E. Zanne. 2010. Functional traits and the growth-mortality trade-off in tropical trees. Ecology 91: 3664-3674.

Zanne, A.E., M. Westoby, D.S. Falster, D.D. Ackerly, S.R. Loarie, S.E.J. Arnold \& D.A. Coomes. 2010. Angiosperm wood structure: Global patterns in vessel anatomy and their relation to wood density and potential conductivity. Am. J. Bot. 97: 207-215. 


\section{SUMMARY AND CONCLUSIONS}

Trees are long living organisms and record ecologically relevant information in their growth rings. Studying tree growth on the base of tree rings can help to fill some of the major research gaps concerning the age and life history of trees as well as their response to changing environmental conditions. Since more than 100 years the existence of annual rings could be proven for many tropical tree species and is largely accepted in the meanwhile. In the last decade methods on tropical dendroecology have advanced rapidly nevertheless the number of studies is still very limited.

Forest ecosystems in tropical regions show high species diversity and a large variability of climatic zones, resulting in a multitude of possible wood anatomical ring structures and resultant relations to ecological and environmental parameters. To ensure the successful application of dendrochronological studies a detailed knowledge of woodanatomical structures and the variability of tree rings is required.

The basic idea of the present dissertation was to contribute to a standardized guidance to determine age and growth rates of tropical tree species in general. Thereby the identification of wood anatomical features in different tree families and species from tropical regions with differences in seasonality of climate was of great concern. The aim was to advance possibilities to reliably detect and describe features of tree-ring boundaries and their highly variable appearance.

Macroscopically apparent growth structures become visible as rings in a cross-section as light/dark zones. Often, different colours within one growth zone can be traced back to the variation in wood density, where the dark zones show a higher density, which is attributed to fibre cells with shortened radial diameters and thickened walls. This is clearly visible in coniferous wood, but also in several broad-leaf families in the tropics. Besides density 
variations a high diversity of growth-zones structures is formed as a composition of different vessel, fibre and parenchyma characteristics.

In CHAPTER 2, the anatomical background of the visibility of tree ring structures was reviewed, presented and explained. An overview of the wood anatomy and tree-ring structures of many tree species from Amazonian floodplain forests was given on a macroscopic level. In general, in floodplain forests trees grow with ring structures suitable for tree-ring analytical studies. Similar to drought stress flooding is a limiting growth factor since the water transport from the roots to the leaves is hindered. Therefore the described aspects of wood and tree-ring formation are not limited to Amazonian floodplain forests, but are of general nature for tropical trees. The analysis of tropical tree ring structures reviewed in CHAPTER 2 stimulated tropical tree-ring analyses as a whole in the last 20 years and helped to overcome the old paradigm that tropical trees do not form annual rings.

Despite the importance of basic data for the evaluation of growth and life history of old-growth tropical forests there is a lack of information about wood growth rates and ages of trees. Traditional methods of age determination are direct radiocarbon measurements of the oldest parts of a tree, calculations from repeated diameter measurements as well as the prediction of longevity from mortality rates. These methods are discussed in CHAPTER 2 as well, leading to the advantages of tree ring analysis to study age and growth rates in tropical trees. Tree-ring analytical studies can be considered for a wide range of applications. Thereby special interest should be paid to gain realistic increment data for the implementation of sustainable management plans, reliable proxy data for tropical climate reconstruction and real tree ages for understanding forest and population dynamics.

To understand natural climate variability and the magnitude of possible human impact on it, high resolution long-term climate data are needed. Tree ring data in particular have a fixed annual resolution and can produce absolute time-series. Long-term ring chronologies are a potentially powerful tool for analyzing demographic trends and ecological factors influencing growth in tropical trees. Basic knowledge of the relationship between environmental variables and tree growth is crucial for the prediction of future growth responses to climatic variation. 
In CHAPTER 3 the dendro-climatic potential of two dominant species from dry forests in Northern Namibia was examined. Both species were sampled at two sites and the response to several climatic variables was studied.

Both species show distinct ring structures. A pronounced seasonality of rainfall appears at both sites, which provides an absolute annual rhythm in radial growth. This is obvious by the fact that the tree species are deciduous, shedding their leaves during the dry season, followed by a cambial dormancy and in consequence visible growth zones are produced. Cross dating of the ring widths over the entire life span of the individual trees was successful for both species at both stands. Successful cross dating between individuals within the same stands expresses an external oscillation factor influencing tree growth. Thus, the growth of the studied tree species is periodical, tied to the annual calendar by seasonality of climate and synchronized among many trees in the same region by inter-annual variation in the shared regional climate.

Both species show a strong correlation between ring width and climate, suggesting that tree growth of these species is sensitive to climate. As all significant responses to rainfall found are positive, higher precipitation rates have a positive influence on tree growth at both sites. The annual nature of tree rings and the possibility of cross-dating in the two studied species implicate major potential for dendrochronological studies in the semi arid forests in Southern Africa. The correlation between rainfall, temperature, relative humidity and tree growth is obvious and is therefore useful for future investigations on tree growth and climate studies. In addition tree growth at one site is correlated to the El Niño Southern Oscillation phenomenon. Tree growth shows response to the atmospheric (SOI) as well as to the oceanic aspect (Niño3.4) of the ENSO phenomenon. The influence of the El Niño phase of the ENSO phenomenon on climate in Southern Africa is a decrease in precipitation and an increase in temperature. The observed negative correlations indicate a tree growth decrease during El Niño years and an increase in La Niña years.

Finally the master chronologies built for both sites present a similar spectral character, both showing a power spectrum peak at a frequency of approximately 0.15 which corresponds to a cycle of approximately 6.7 years and does fall in the broad spectral peak corresponding to 2 to 8 years, which characterizes the variability of ENSO-related time-series and could thus be attributed to the ENSO phenomenon. 
Overall the results of CHAPTER 3 show that as cross dating among different species was possible for both sites, a common influence on a regional scale can be considered. The significant response of tree growth to climate variables underlines this statement. The results of this study yield additional indication for the notion that tropical trees are sensitive to variation in climate patterns and are a source of reliable tree ring data.

A further objective of this dissertation is to identify new quantitative parameters to define ring boundaries. One attempt was the analysis of stable carbon isotope variation together with wood-anatomical variables along radial tree-ring sequences. The profiles were examined with respect to changes that indicate annual cycles and hence could possibly be used to verify annual growth-ring formation.

The analysis of stable carbon isotope ratios in tree rings is a more recent approach to study growth responses of trees to climatic changes and variation that has primarily been applied on trees from temperate zones. In CHAPTER 4 trees from different hydrological sites were compared to define how rainfall variations are influencing ${ }^{13} \mathrm{C}$ fractionation in tropical trees to enable a better interpretation of stable isotope patterns in the wood. At high resolution a similar intra-annual pattern of $\delta^{13} \mathrm{C}$ was found that has been described for trees from temperate zones as well as for mangrove trees from Kenya, Africa. However the study did not provide sufficient results to contribute to the general detection and determination of tree ring boundaries exclusively on the base of intra annual $\delta^{13} \mathrm{C}$ sequences. Doubtless detection of ring boundaries in the isotope sequences was only possible in broad rings with high resolution measurements or in combination with careful wood anatomical examination.

Nevertheless $\delta^{13} \mathrm{C}$ inter-annual time series of tree individuals of the same species from the same sites, showed significant correlations, indicating a common external factor that triggers stable-carbon isotope discrimination. Comparing different species from the same site or the same species from different sites, no consistent results were achieved.

The correlation between precipitation time series and tree-ring isotopic data was significantly negative indicating a higher fractionation against ${ }^{13} \mathrm{C}$ during drier years resulting in less negative $\delta^{13} \mathrm{C}$ values. The significant correlations found were evenly strong and independent of the general humidity differences of the sites or the phenology of the trees. Growth-limiting factors are typically reported as being responsible for the isotopic 
fractionation in plants. The relationship between precipitation and stable-carbon isotope time series can be interpreted in this context and is underlined by the negative correlation between mean $\delta^{13} \mathrm{C}$ values for tree individuals and the mean annual precipitation at the site.

The results of this study showed that tropical trees, like trees from temperate zones, are recording carbon isotopic signals in the wood, which can be linked to specific external factors like rainfall and can be used to date tropical trees.

Finally, the most important objective of this dissertation was to study quantitative wood anatomy in tropical tree rings. One approach was to identify quantitative anatomical thresholds that could be used to detect ring boundaries. During an extensive experimental phase on different image analysis techniques on various wood anatomical parameters, no promising results could be achieved. In some tree species with distinct annual ring structures the measurement of vessel variables as well as fibre and parenchyma cross-sectional area resulted in profiles exhibiting sudden changes at the ring boundaries. In species showing less distinct structures these pattern could not be observed without doubt. Quantitative wood anatomical measurements may support the determination of ring boundaries with careful qualitative wood anatomical examination. However, these measurements are very time consuming and are unsuitable to substitute the individual qualitative examination on every stem disc.

The anatomical composition imbeds a high plasticity of the wood structure within one species or even a single individual which is supposed to be the result of the influence of varying environmental factors. For a better understanding of the relations between external factors and wood structure wood anatomical variables of tropical trees across taxa and a wide climatic gradient were analyzed in CHAPTER 5. The variation of wood anatomical variables (e.g. vessel diameter or frequency, cross-sectional area occupied by vessel, fibre or parenchyma tissue) within and between tree individuals, families and sites was tested. In addition, wood anatomical variables were examined concerning their relation to parameters of tree morphology (DBH, height and crown exposure to light) and general environmental conditions (mean annual precipitation and mean duration of "unfavourable" growth conditions like drought or flooding). Beneath the vessel parameters, which were measured directly, a couple of derived estimates (e.g. hydraulic conductivity) were added to the data set. 
Wood anatomical variables and estimates were combined with a unique data set on climate, site and forest stand conditions on an individual base.

The results exhibited a great within-tree, within-species and within-site variation of wood anatomical variables. This variation was greater than between-species and -site variation in general. By relating wood anatomical variables with each other, the most consistent results were gained for the variable vessel diameter which was negatively correlated with vessel frequency. This finding mirrors two contrasting concepts of water transport systems. Basically wide vessels are the most efficient water conductors since the water conductivity increases with the fourth power of vessel diameter and only with the first power of vessel frequency. The ecological disadvantage of the large vessels is their vulnerability to cavitation. Furthermore, vessel diameter showed close correlations between climate and tree morphological parameters. Vessel diameter was positivly correlated with dominant tree growth (DBH, height, crown exposure). Principal component analysis also showed the correlation between tree size and an efficient water transport system. This relation is necessary to provide the large leaf area of a tall and dominant tree with water for transpiration and photosynthesis.

In addition, vessel diameter was negativly influenced by increasing duration of the stress period and positivly correlated with mean annual precipitation of the site. These interrelations can be interpreted in the context of the trade-off between efficiency and safety of the hydraulic system of the stem. The high variations of wood anatomical variables at given sites indicate the co-existence of different strategies in the vascular design of the stem. Major properties that are hydraulically relevant such as vessel structure, leaf stomatal behaviour or the kind of root system, generally define the range of a species' tolerance and competitiveness and thus the ecological setting to which a species is adapted. Moreover, a stronger influence of the parameter STRESS could be observed. The vegetation period in stressful environments is considerably shorter and forces the trees to perform all important physiological processes that ensure growth, reproduction and survival in a very constricted time frame. These constraints demand a water transport system that ensures maximum efficiency at the lowest possible cavitation risk. Thereby deciduous tree species avoid stress by shedding their leaves, possibly allowing lower cavitation resistance and larger vessels, while evergreen species can tolerate unfavourable growing conditions possibly due a higher cavitation resistance with smaller vessels and by slowing down or stopping physiological processes. Survival and 
competitiveness of tree species depend on their general stress avoidance strategy but also on their ability to adjust and optimize their hydraulic architecture by differences in vessel size and frequency to varying environmental conditions from year to year. In conclusion the lower vessel diameter range observed at stressed sites can be traced back to extreme macro-climatic site conditions. The high variation of vessel diameter within these sites can be attributed to different plant strategies and the strong impact of individual tree morphology.

Finally a very remarkable result was the observed influence of climate factors on the tissue compostion of trees as only little is known on the significance of this relation. The principal component analyses indicate a strong positive relation between parenchyma crosssectional area and the magnitude of stress and a strong negative relation between fibre crosssectional area and stress. This observation reflects the trade-off between growth and survival: The investment in parenchyma at stressed sites guarantees a better and faster supply with reserves promoting a fast flushing and production of early wood at the beginning of a short vegetation period. That means that the investment in parenchyma is not random, but clearly reflects the mechanisms of carbohydrate storage and mobilization as a function of specific phenological behaviour triggered by the dominating and limiting external growth factor. Therefore trees that are less exposed to stress seem to be able to invest more carbon in fibre cell structures that guarantees survival through protection against mechanical and chemical forces while trees exposed to longer stress periods require more investment in parenchyma structures to ensure better growth within short vegetation periods. So far, only little is known on the ecological significance of these relevant wood anatomical variables and therefore the observed direct influence of climate on the parenchyma and fibre cross sectional area gives direction to future analyses.

Plant growth and survival is shaped by a multitude of root, stem and leaf characteristics and influenced by environmental site conditions. The inter-relation of these factors might shift depending on phylogenetic constraints, individual tree morphology as well as climate variability. To further encode the strength of the influencing factors of wood anatomical variables future analyses should be based on the comparison of different plant families. Within a certain range that is dominantly influenced by tree morphology individual trees show a high plasticity of wood anatomical variables. Therefore future dendrochronological studies should consider a direct link between this variability of wood anatomical structures with short term oscillating environmental changes. 
Annual time series of the investigated parameters in the different chapters of this dissertation showed that tropical trees rings store manifold ecological information. The differences within individuals might show how trees can adapt or adjust to environmental variability and can provide information about the plasticity of a species under changing environmental conditions but have to be related directly to annual climate variability. Time series of ring width, stable carbon isotope composition and wood anatomical variables are valuable contributions to dendrochronology in the tropics and are further steps on the way to close the existent research gaps in tropical forest ecology and climate change. 


\section{ZUSAMMENFASSUNG}

Bäume sind langlebige Organismen und speichern ökologisch relevante Informationen in ihren Jahresringen. Untersuchungen des Baumwachstums auf der Grundlage von Jahresringen können dazu beitragen, wichtige Information über Alter und Zuwachs zu erlangen, aber auch wichtige Fragen bezüglich ihrer Reaktionen auf sich ändernde Umweltbedingungen zu beantworten. Vor bereits mehr als 100 Jahren wurde die Existenz von Jahresringen in tropischen Bäumen für viele Arten nachgewiesen und ist mittlerweile weithin akzeptiert. Obwohl dendroökologische Methoden in den letzten zehn Jahren ständig weiterentwickelt wurden, ist die Anzahl der durchgeführten Untersuchungen eher gering.

Tropische Waldökosysteme weisen eine sehr große Artenvielfalt und ein breites Spektrum an klimatischen Zonen auf. Diese große Variabilität äußert sich auch in einer Vielzahl von möglichen holzanatomischen Strukturen und entsprechenden Beziehungen zu ökologischen und umgebungsbedingten Faktoren. Die erfolgreiche Anwendung dendrochronologischer Methoden in den Tropen bedingt daher ausführliche Kenntnisse holzanatomischer Strukturen und deren Variabilität zur eindeutigen Bestimmung von Jahresringen in tropischen Bäumen.

Die Grundidee der vorliegenden Arbeit war es, eine standardisierte Anleitung zu entwickeln, um Jahresringgrenzen zu erkennen und so eine Alters- und Zuwachsbestimmung an tropischen Bäumen durchführen zu können. Dabei stand die holzanatomische Beschreibung der Jahrringgrenzen und ihrer Variabilität für verschiedenste Baumarten von klimatisch unterschiedlichen Standorten im Vordergrund. Ein besonderes Ziel war es, die Möglichkeiten einer unabhängigen Erfassung der Ringgrenzen durch quantitative Parameter zu prüfen und zu beschreiben.

Makroskopisch sichtbare Zuwächse erscheinen im Querschnitt als Ringstrukturen, die als helle und dunkle Zonen erkennbar sind. In vielen Fällen können diese verschiedenen Farben innerhalb einer Zuwachszone auf Unterschiede in der Holzdichte zurückgeführt werden, wobei dunkle Zonen eine höhere Dichte anzeigen, die durch Faserzellen mit verkürzten radialen Durchmessern und verdickten Zellwänden begründet ist. Dies ist generell deutlich sichtbar in Nadelholz aber auch in vielen Laubbaumarten der Tropen. Die große Vielfalt tropischer Baumarten spiegelt sich auch in einer großen Diversität der Zuwachszonen wider, ein Resultat verschiedener Gefäß-, Faser-, und Parenchymeigenschaften. 
In KAPITEL 2 wird der holzanatomische Hintergrund der makroskopischen Sichtbarkeit von Ringstrukturen behandelt und am Beispiel vieler Baumarten aus Überschwemmungswäldern des Amazonas belegt. Im Allgemeinen bilden Bäume dieser Wälder Jahresringe aus, die auch für dendrochronologische Untersuchungen geeignet sind. Die beschriebenen Aspekte der Holz- und Ringstrukturen sind nicht auf diese Überschwemmungswälder begrenzt, sondern lassen sich in Bäumen aller tropischen Wälder wiederfinden. Die in KAPITEL 2 diskutierten Ergebnisse haben in den letzten 20 Jahren die tropische Jahrringanalyse angeregt und darüber hinaus das Paradigma überwinden können, dass tropische Bäume keine Jahresringe ausbilden.

Obwohl das Grundwissen über Alter und Wachstum tropischer Wälder von großer Bedeutung für deren Bewertung ist, besteht derzeit noch eine enorme Wissenslücke bezüglich des Alters und des Zuwachses tropischer Bäume. Traditionelle Methoden der Altersbestimmung sind die Radiokarbondatierung des Stammzentrums, Schätzungen auf der Grundlage wiederholter Durchmesserbestimmungen oder Modellrechnungen auf der Grundlage von Sterblichkeitsraten. Diese Methoden werden in KAPITEL 2 diskutiert und leiten über zu den Vorteilen der Jahrringanalyse zur Bestimmung von Alter und Zuwachs tropischer Bäume. Darüber hinaus können dendrochronologische Untersuchungen für eine Vielzahl weitere Anwendungen berücksichtigt werden. Besonders erwähnenswert sind dabei die realistische Erfassung der Zuwachsraten zur Entwicklung nachhaltiger Waldbewirtschaftungspläne, das Erstellen von Näherungswerten für Klimarekonstruktionen und für die Bestimmung des Baumalters in Bezug auf Wald- und Populationsdynamik.

Um die natürliche Klimavariabilität und das Ausmaß des anthropogenen Einflusses darauf erfassen und verstehen $\mathrm{zu}$ können, werden hochaufgelöste, lange Klimazeitreihen benötigt. Jahresringe sind für solche Zeitreihen besonders geeignet, da sie eine festgelegte jährliche Auflösung beinhalten. Lange Jahrringchronologien sind besonders sinnvolle Hilfsmittel bei der Analyse der demographischen Entwicklung tropischer Bäume und für die Entschlüsselung ökologischer Einflussfaktoren. Um die zukünftige Reaktion von Bäumen auf Klimaveränderungen abschätzen zu können, ist es wichtig, ein grundlegendes Wissen über die Klima-Wachstumsbeziehungen von Bäumen zu besitzen.

In KAPITEL 3 wird das dendroklimatologische Potenzial von zwei dominanten Baumarten aus Trockenwäldern in Namibia untersucht. Von beiden Baumarten wurden an zwei unterschiedlichen Standorten Stammscheiben entnommen und die Klima-WachstumsBeziehungen anhand der Ringbreiten in Bezug zu Klimaparametern analysiert. 
Beide Arten weisen deutliche Ringstrukturen auf, die aufgrund der ausgedehnten jährlichen Trockenzeit, in der die Bäume ihr Laub abwerfen, als Jahresringe definiert werden können. Kreuzdatierungen der Ringbreiten konnten für Individuen (verschiedene Radien) erfolgreich durchgeführt werden. Die erfolgreiche Kreuzdatierung von Zeitreihen verschiedener Individuen eines Standortes wies auf einen externen Faktor hin, der das Baumwachstum beeinflusst.

Für beide Arten konnte eine starke Korrelation zwischen Baumwachstum und Klimazeitreihen festgestellt werden. Alle signifikanten Korrelationen zum Niederschlag waren positiv, was bedeutet, dass höhere Niederschlagsraten einen positiven Einfluss auf das Baumwachstum haben. Darüber hinaus zeigt das Baumwachstum an einem der beiden Standorte einen Zusammenhang mit dem El Niño - Südliche Oszillation Phänomen (ENSO). Das Baumwachstum reagiert sowohl auf den atmosphärischen (SOI) wie auch auf den ozeanischen (Niño3.4) Aspekt dieses Phänomens. Der Einfluss der El Niño Phasen des Phänomens auf das Klima im südlichen Afrika beinhaltet verringerte Niederschläge in Verbindung mit steigenden Temperaturen. Der beobachtete Zusammenhang zwischen Baumwachstum und ENSO beschreibt reduziertes Baumwachstum während der warmen El Niño Phasen und erhöhte Zuwächse währen kalter La Niña Phasen. Schließlich zeigten die Chronologien der beiden Standorte in der Spektralanalyse ähnliche Eigenschaften, wobei beide Zeitreihen eine maximale spektrale Leistungsdichte bei einer Frequenz von 0,15 aufwiesen, was einem Intervall von 6,7 Jahren entspricht. Dieser Wert liegt im Bereich der charakteristischen spektralen Leistungsdichte der Variation von ENSO-beeinflussten Zeitreihen von zwei bis acht Jahren und kann somit auf das ENSO-Phänomen zurückgeführt werden.

Die erfolgreiche Kreuzdatierung der beiden Arten beinhaltet großes dendroklimatologisches Potenzial für weitere Untersuchungen in semiariden Wäldern im südlichen Afrika.

Ein weiteres Ziel dieser Dissertation war, neue quantitative Parameter zur Erkennung von Ringgrenzen zu identifizieren. Ein Ansatz war die Analyse stabiler Kohlenstoffisotope zusammen mit holzanatomischen Merkmalen entlang von radialen Jahrringsequenzen. Die Profile wurden auf Änderungen, die auf jährliche Zyklen deuten, untersucht, damit diese möglicherweise zur Verifizierung jährlicher Ringstrukturen genutzt werden können.

Die Analyse stabiler Kohlenstoffisotope in Jahresringen ist ein relativ neuer Ansatz zur Erforschung von Wuchsreaktionen auf Klimaänderungen und -variation, der bisher 
hauptsächlich auf Bäume gemäßigter Zonen angewandt wurde. In KAPITEL 4 wurden Bäume verschiedener hydrologischer Standorte verglichen, um festzustellen, welchen Einfluss Niederschlagsunterschiede auf ${ }^{13} \mathrm{C}$-Diskriminierung in tropischen Bäumen haben. Dies sollte eine bessere Interpretation von stabilen Isotopenmustern ermöglichen. Bei hoher Auflösung wurde ein ähnliches intra-anuelles Muster von $\delta^{13} \mathrm{C}$ gefunden, wie es für Bäumen aus temperaten Zonen oder Mangroven aus Kenia beschrieben wurde. Die Studie konnte trotzdem keine zufriedenstellenden Ergebnisse als Beitrag zur allgemeinen Erkennung und Festlegung von Ringgrenzen ausschließlich aufgrund intra-annueller $\delta^{13} \mathrm{C}$-Sequenzen liefern. Zweifelsfreie Erkennung von Ringgrenzen in den Isotopensequenzen war nur in breiten Ringen mit hochaufgelösten Messungen oder in Kombination mit sorgfältiger holzanatomischer Untersuchung möglich.

$\delta^{13} \mathrm{C}$ inter-annuelle Zeitreihen für Baumindividuen des selben Standorts sind dennoch signifikant korreliert, was auf gemeinsame externe Faktoren zur Auslösung der Diskriminierung stabiler Kohlenstoffisotope hinweist. Beim Vergleich verschiedener Arten eines Standorts oder derselben Art von verschiedenen Standorten wurden keine einheitlichen Ergebnisse erzielt.

Die Korrelation zwischen Niederschlags-Zeitreihen und den Isotopenwerten der Jahresringe war signifikant negativ. Die beobachteten Zusammenhänge waren sowohl unabhängig von den hydrologischen Bedingung des Standortes als auch der Phänologie der Bäume. Wachstumsbeschränkende Faktoren werden traditionell für die IsotopenDiskriminierungsprozesse verantwortlich gemacht. Die Beziehung zwischen Niederschlag und Zeitreihen stabiler Kohlenstoffisotope können in diesem Zusammenhang interpretiert werden. Die generell negative Korrelation zwischen $\delta^{13} \mathrm{C}$ im Holz und dem Niederschlag wird weiterhin bestätigt durch die negative Korrelation in dieser Studie zwischen $\delta^{13} \mathrm{C}$-Werten von Baumindividuen und den allgemeinen hydrologischen Verhältnissen am Wuchsort.

Die Ergebnisse dieser Studie zeigten, dass tropische Bäume, wie Bäume gemäßigter Zonen, Kohlenstoffisotopensignaturen im Holz speichern. Diese können mit externen Faktoren in Verbindung gebracht werden und zur Altersbestimmung tropischer Bäume genutzt werden.

Das wichtigste Ziel dieser Dissertation war schließlich, quantitative holzanatomische Merkmale in Jahresringen tropischer Bäume zu untersuchen. Wie auch bei der Betrachtung stabiler Isotope war ein Ansatz, quantitativ anatomische Merkmale zu erfassen, die zur Identifizierung von Ringgrenzen genutzt werden können. Während einer ausgedehnten 
Testphase unterschiedlicher Bildanalysetechniken für verschiedene holzanatomische Parameter konnten keine zufriedenstellenden Ergebnisse erzielt werden. In einigen Baumarten mit deutlichen Jahrringstrukturen führte die Messung von Gefäßvariablen, wie auch Flächenanteilen von Fasern und Parenchym zu Profilen, die plötzliche Änderungen an Ringgrenzen aufwiesen. Bei Arten mit weniger deutlichen Strukturen konnten diese Muster nicht beobachtet werden. Wie auch die Isotopenanalyse in KAPITEL 4 zeigte, können quantitative holzanatomische Messungen die Erkennung von Ringgrenzen durch sorgfältige qualitative holzanatomische Untersuchung unterstützen. Diese Messungen beinhalten einen enormen Arbeitsaufwand, können jedoch die individuelle qualitative Untersuchung jeder Stammscheibe nicht ersetzen.

Die anatomische Einordnung wird erschwert durch eine hohe Plastizität der Holzstruktur innerhalb einer Art oder sogar innerhalb eines Baumindividuums, was als Resultat des Einflusses sich ändernder Umwelteinflüsse gedeutet wird. Zum besseren Verständnis der Beziehungen zwischen externen Faktoren und der Holzstruktur wurden in KAPITEL 5 holzanatomische Merkmale tropischer Bäume verschiedener Taxa entlang eines weiten Klimagradienten analysiert. Die Variation holzanatomischer Merkmale (z.B. Gefäßdurchmesser oder -frequenz, Gefäß-, Faser- oder Parenchymflächenanteil) innerhalb und zwischen Baumindividuen, Familien und Standorten wurde untersucht. Weiterhin wurden holzanatomische Merkmale auf ihre Beziehung zu Parametern des Baumwachstums und der Gestalt (BHD, Höhe und Kronenexposition), sowie generellen Umweltfaktoren (durchschnittlicher Niederschlag, durchschnittliche Dauer “ungünstiger” Wuchsbedingungen) geprüft. $\mathrm{Zu}$ den direkt gemessenen Gefäßparametern wurden einige abgeleitete Werte (z.B. die Wasserleitfähigkeit der einzelnen Jahresringe) dem Datenpool zugefügt. Holzanatomische und abgeleitete Werte wurden mit einem einzigartigen Datensatz zu Klima-, Standort- und Bestandsbedingungen auf individueller Basis kombiniert.

Die Ergebnisse zeigen eine große Variation innerhalb von Baumindividuen, aber auch innerhalb von Familien und Standorten. Diese Vielfalt war größer als die Variation zwischen einzelnen Familien und Standorten. Bei der Analyse der Beziehungen der holzanatomischen Merkmale untereinander wies der Gefäßdurchmesser die deutlichsten Ergebnisse auf. Der Gefäßdurchmesser war negativ korreliert mit der Gefäßfrequenz. Diese Beziehung spiegelt zwei unterschiedliche Konzepte des Wassertransportes im Stamm wider. Generell sind große Gefäße die besseren Wasserleiter, die hydraulische Leitfähigkeit erhöht sich um die vierte Potenz des Gefäßdurchmessers, allerdings nur um die erste Potenz der Gefäßfrequenz. Der 
ökologische Nachteil großer Gefäße hingegen ist deren Anfälligkeit gegenüber Kavitation und Embolien.

Darüber hinaus zeigte der Gefäßdurchmesser die stärkste Korrelation mit generellen Klimamerkmalen, sowie Baumwachstum und -gestalt. Der Gefäßdurchmesser war positiv korreliert mit gutem Baumwachstum und dominantem Erscheinungsbild (BHD, Höhe und Krone). Diese Beziehungen deuten darauf hin, dass dominante und gutwüchsige Bäume auf eine effiziente Wasserversorgung angewiesen sind, um eine exponierte Krone mit Wasser zu versorgen, die Photosyntheseleistung zu maximieren und damit die Bildung von Holz zu sichern. Darüber hinaus war der Gefäßdurchmesser negativ korreliert mit zunehmender Länge der Stressperiode und positiv korreliert mit zunehmendem Jahresniederschlag. Diese unterschiedlichen Wechselbeziehungen können im Zusammenhang mit dem Ausgleich von Effizienz und Sicherheit des Wasserleitsystems interpretiert werden.

Ein bemerkenswertes Ergebnis lieferte die Analyse der relativen Flächenanteile von Gefäßen, Faserzellen und Parenchym. Bis heute ist nur wenig über die Ursachen der Aufteilung in verschiedene Zelltypen bekannt. In diesem Datensatz konnte jedoch ein Zusammenhang zwischen den Klimabedingungen und der relativen Verteilung der Zelltypen hergestellt werden. Faseranteile waren positiv mit dem jährlichen Niederschlag und die Parenchymanteile positiv mit der Länge der Stressperiode korreliert. Diese Wechselbeziehung kann im Zusammenhang mit dem Kompromiss zwischen maximalem Wachstum und Langlebigkeit interpretiert werden. Bildung von mehr Parenchymgewebe an gestressten Standorten sichert bessere und schnellere Verfügbarkeit von Energie während kurzer Vegetationsperioden und ermöglicht so optimales Wachstum. Bäume an weniger gestressten Standorten scheinen mehr Energie in die Bildung von Faserzellen zu investieren, was einen effektiven Schutz vor mechanischer und chemischer Belastung und so bessere Überlebensraten impliziert.

Das Wachstum und das Überleben von Pflanzen werden durch eine Vielzahl von Wurzel-, Stamm- und Blatteigenschaften bestimmt und darüber hinaus durch externe Standortfaktoren beeinflusst. Mit Hilfe einer Hauptkomponentenanlyse in KAPITEL 5 konnten die Wechselbeziehungen einiger dieser Faktoren aufgezeigt werden. Hierbei zeigte sich, dass das Baumwachstum den stärksten Einfluss auf den Kompromiss zwischen Effizienz und Sicherheit des Wasserleitsystems hat. Auch die Klimabedingungen zeigten einen Einfluss auf das Wasserleitsystem, jedoch ist die Aufteilung in unterschiedliche Gewebearten stärker durch Klimafaktoren bestimmt. Generell können sich diese Wechselbeziehungen aber aufgrund von phylogenetischen Grenzen, individueller Wuchsleistung und aufgrund 
klimatischer Veränderungen verschieben. Die Eigenheiten und die Intensität der Einflussfaktoren auf die holzanatomischen Merkmale sollte weiter untersucht werden. Dabei ist zunächst die Konzentration auf einzelne Familien zu empfehlen unter Berücksichtigung der inter-annuellen Variabilität des Holzes und des Klimas.

Die Analyse der Jahresringe in Bezug auf deren Ringbreiten, stabilen Kohlenstoffisotopen-Gehalt und quantitative holzanatomische Merkmale zeigt, dass tropische Jahresringe vielfältige ökologische Informationen speichern. Die große individuelle Variabilität spiegelt die Anpassungsfähigkeit an veränderliche Standortbedingungen wider und sollte daher direkt mit Klimazeitreihen in Verbindung gebracht werden. Die verschieden Untersuchungen dieser Dissertation leisten damit einen wichtigen Beitrag zur Weiterentwicklung der Tropischen Dendrochronologie. Die Anwendung der vorgestellten Methoden kann somit dazu beitragen, wichtige Forschungslücken auf dem Gebiet der Ökologie tropischer Wälder und des Klimawandels zu schließen. 


\section{ACKNOWLEDGEMENTS}

I want to thank Martin Worbes for welcoming me in his tree ring working group. I am grateful for the guidance, objectivity and profitable discussions about this research.

I also wish to thank Rupert Wimmer for his willingness to act as second referee on this manuscript.

This study would not have been possible without the financial support of the German Federal Environmental Foundation (DBU) which sponsored this work by the Scholarship Programme.

I gratefully acknowledge the support of all my colleagues from the division of Crop Production Systems in the Tropics for their personal and technical assistance during my study. Special thanks go to Ute Ronsöhr!

In the same way I want to thank my colleagues and good friends Valerie Trouet (Laboratory of Tree-Ring Research) \& Ute Sass-Klaassen (Wageningen University) for many pleasant and inspiring talks \& discussions.

Thanks to all my friends everywhere for their support but especially for the variety they bring in my life!

I want to thank my family and all loved ones for their continuous support, their belief and patience. 


\section{CURRICULUM VITAE}

\section{Personal}

Name:

Esther Fichtler (ex. Naumer)

Date of Birth:

$03^{\text {rd }}$ Feb 1976

Place of Birth:

Neustadt an der Weinstraße, Germany

Nationality:

german

Civil status:

married, two children

\section{Education}

08/1982 - 06/1986

Grundschule Mußbach

08/1986 - 06/1995

Kurfürst-Ruprecht-Gymnasium, Neustadt an der Weinstraße

Abitur

$10 / 1996-11 / 2001$

Georg-August-University Göttingen, Faculty of Forest Sciences and Forest Ecology

Major subject: Tropical and International Forestry

Master of Science (M.Sc.)

$02 / 2002-05 / 2011$

PhD student at Georg-August-University Göttingen, Faculty of Forest Sciences and Forest Ecology, sponsored by the Scholarship Programme of the German Federal Environmental Foundation (DBU) 